\title{
Los maestros ante la violencia escolar
}

든

()

()

No. 4

\section{Bárbara Yadira García Sánchez Blanca Inés Ortiz Molina}






\section{Los maestros ante la violencia escolar}

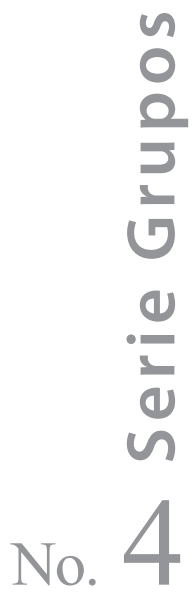

Bárbara Yadira García Sánchez Blanca Inés Ortiz Molina 


\section{UNIVERSIDAD DISTRITAL FRANCISCO JOSÉ DE CALDAS}

Rector

Inocencio Bahamon Calderon

Vicerrectoría Académica

María Elvira Rodríguez Luna

Vicerrectoría Administrativa y Financiera

Álvaro León Rojas

Sección Publicaciones - Jefe

Rubén Eliecer Carvajalino Carvajalino

COMITÉ EDITORIAL - CADE

Presidenta CADE

Adela Molina Andrade

Representante grupos de investigación Interculturalidad, Ciencia y Tecnología INTERCITEC, y del Grupo Didáctica de la Química - DIDAQUIM. Del énfasis de Educación en Ciencias.

\section{Álvaro García Martínez}

Representante de los grupos de investigación Identidad, Lenguaje y Cultura, Moralia, Estudios del Discurso, Educación Comunicación y Cultura del énfasis de Lenguaje y Educación.

\section{Sandra Soler Castillo}

Representante de los grupos de investigación: Interdisciplinaria en Pedagogía de Lenguaje y las Matemáticas GIIPLyM Matemáticas Escolares Universidad Distrital - MESCUD , del énfasis de Educación Matemática.

Olga Lucia León Corredor
Representante de los grupos de investigación Formación de Educadores, del énfasis de Historia de la Educación, Pedagogía y Educación Comparada.

Rigoberto Castillo

Representante de los estudiantes -se elige el 16 de Mayo de 2012 por votación virtual.

José Javier Betancourt Godoy

COMITÉ EDITORIAL INTERINSTITUCIONAL - CAIDE

Directora Nacional

Margie Nohemy Jessup C.

Coordinadora DIE -Universidad

Pedagógica Nacional

Rosalba Pulido de Castellanos

Coordinadora DIE - Universidad Distrital Francisco José de Caldas

Adela Molina Andrade

Coordinador DIE - Universidad del Valle

Eric Rodríguez Woroniuc

(C) Universidad Distrital Francisco

José de Caldas

ISBN: 978-958-8782-05-8

e-ISBN: 978-958-8782-94-2

Primera edición, 2012

Diseño, Diagramación e impresión

Fundación Común Presencia

Prohibida la reproducción total o parcial sin permiso escrito de la Universidad Distrital Francisco José de Caldas.

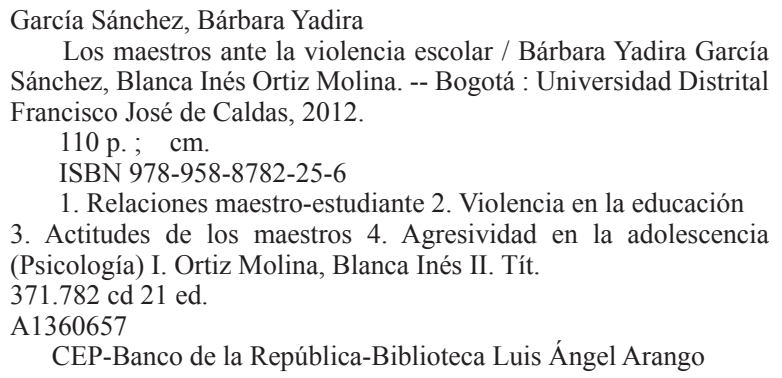


Agradecimientos 9

Introducción 11

Función social de la educación 13

Nuevas obligaciones de las instituciones educativas. Código de Infancia y Adolescencia

La violencia escolar en Bogotá desde la mirada de los maestros $\quad 21$

La mirada del maestro sobre sí mismo. Su historia 23

El maestro sujeto de reflexión $\quad 24$

Sentido de pertenencia y compromiso 25

$\begin{array}{ll}\text { Las relaciones socio afectivas } & 27\end{array}$

Identidad docente refundida, negación de la profesión 28

Concepciones sobre la violencia 30

La violencia: carga negativa de su enunciado 31

La violencia: ausencia de tolerancia 32

La violencia como algo exterior a la institución educativa 35

Los maestros en entornos violentos: Maestro como agente de cambio 36

La violencia secreta en las instituciones 36

La violencia y las interacciones de poder y exclusión 37

Contextos que influyen en la violencia 38

Sentido de la violencia 39

Papel del profesor frente a la violencia $\quad 40$

El manejo del conflicto $\quad 41$

El apoyo institucional 42

La percepción que el profesor tiene del estudiante 42

Espacios y tipos de agresividad 43 
Clima Escolar $\quad 43$

Percepciones sobre el clima general de la institución. $\quad 45$

$\begin{array}{ll}\text { Percepción de los espacios físicos } & 47\end{array}$

Percepción de la relación con los colegas $\quad 49$

Percepciones de la relación con los directivos 51

Disciplinamiento asociado a situaciones de violencia escolar $\quad 55$

La nueva responsabilidad pedagógica 56

$\begin{array}{ll}\text { Prácticas de disciplinamiento escolar } & 57\end{array}$

Del disciplinamiento a la exclusión social 63

La evasión del hogar $\quad 69$

Evasión escolar $\quad 73$

Ausentismo escolar $\quad 77$

$\begin{array}{ll}\text { Suspensión escolar } & 79\end{array}$

$\begin{array}{ll}\text { Desescolarización: modalidades } & 80\end{array}$

Desescolarización: falta disciplinaria por irrespeto a la autoridad del maestro 83

Desescolarización por maltrato físico leve entre compañeros 84

Desescolarización por moda y rebeldía adolescente 85

Deserción escolar $\quad 88$

Expulsión escolar $\quad 95$

$\begin{array}{ll}\text { A manera de conclusiones } & 101\end{array}$

$\begin{array}{ll}\text { Referencias bibliográficas } & 103\end{array}$

Índice de cuadros

Cuadro 1. Razones para no estudiar en Colombia: población de 5 a 17 años 1997 y 2003

Cuadro 2. Deserción intra-anual en Bogotá 2002-2005 91

Cuadro 3. Razones de la deserción escolar en Bogotá 2002-2005 92 
Índice de figuras

Figura 1. Prácticas de disciplinamiento

Figura 2. Motivos para la evasión del hogar

Figura 3. Motivos para la evasión escolar

Figura 4. Deserción escolar en Bogotá 2002-2005 por género

Figura 5. Tipo de familia y problemáticas escolares asociadas 



\section{Agradecimientos}

Muchas son las personas e instituciones que colaboraron en el proceso de dos años y medio de investigación-acción. Algunas merecen mención y agradecimiento especial:

A las entidades que financiaron esta investigación titulada La violencia escolar en Bogotá: una mirada desde los maestros, las familias y los jóvenes. Aplicación de un modelo cualitativo de investigación y prevención en escuela, familia y barrio: A ColcIENCIAS, a la Universidad Distrital Francisco José de Caldas y a la Universidad Pedagógica y Tecnológica de Colombia. Al Doctorado Interinstitucional en Educación de la Universidad Distrital y al Doctorado en Historia de la Universidad Pedagógica y Tecnológica de Colombia. A los grupos de investigación Formación de Educadores y Conflictos Sociales Siglo XX.

A Catherine Blaya-Debarbieux, Doctora en Ciencias Sociales, profesora del Departamento de Ciencias de la Educación de la Universidad de Bourgogne y cofundadora y miembro del Observatorio Europeo de la Violencia Escolar, ahora denominado Observatorio Internacional de la Violencia Escolar, quien asesoró esta investigación y además participó en numerosos eventos que se realizaron en el marco del proyecto, como las jornadas pedagógicas en Bogotá y las Jornada Internacional sobre Violencia Escolar realizada en la UPTC en Tunja, así como el desarrollo de un seminario y algunas conferencias.

A María Isabel Bernal Ardila, Marisol Cruz Ramírez e Ingrid Carolina Pabón Suárez, asistentes de investigación, quienes colaboraron transcribiendo, catalogando y sistematizando información de fuentes primarias, secundarias y de archivos institucionales de las Comisarías de Familia a través de fichajes y de la construcción y administración de las bases de datos, apoyo en la realización de entrevistas, grupos focales y NES con padres y madres de familia, docentes y líderes barriales y apoyo en la realización de eventos académicos propios del proyecto, entre otras actividades.

A Carmen Beatriz Torres Castro y Luz Stella Cañón Cueca, estudiantes del Doctorado Interinstitucional en Educación de la Universidad Distrital, quienes 
realizaron el trabajo de campo de sus tesis doctorales en el marco de esta investigación sobre violencia escolar femenina y la asociada a las barras del fútbol, a Jaime Mauricio Gutiérrez y Luz Nelly Novoa Vargas, estudiantes del Doctorado en Ciencias de la Educación de RudEColombia, CADE Tunja, quienes acompañaron el trabajo de campo y participaron en las sesiones de reflexión y evaluación de la información obtenida en cada uno de los escenarios investigados.

A la Doctora Adela Molina Andrade, Directora del Doctorado Interinstitucional en Educación de la Universidad Distrital Francisco José de Caldas y al CADE DIE-UD, por el apoyo para la publicación de los cuatro libros resultantes de la investigación.

A los autores de esta colección que hoy presentamos: Violencias en contexto: la ciudad, el barrio y la violencia escolar; Núcleos de Educación Social NES, Investigación, prevención y participación con metodología IAP; La violencia escolar en Bogotá desde la mirada de las familias y Los maestros ante la violencia escolar.

Gracias también a los directivos(as) docentes, a los maestros(as), a los padres y madres de familia, a los y las adolescentes, a los y las lideres barriales de las instituciones educativas de las localidades de Usaquén, Suba, Fontibón, Usme y Santa Fe, que nos hicieron sus confidentes y compartieron con nosotros experiencias, percepciones, vivencias y miedos relacionados con situaciones de violencia.

Pero sobre todo a los jóvenes del siglo XXI por llenarnos de esperanza en medio de la incertidumbre. 
Nuestras reflexiones acerca de la violencia escolar resultan de un proceso de indagar y comprender compartido, de una reflexión grupal, sistemática y sostenida. Nos centramos en los resultados del escenario maestros, su mirada de sí, sus concepciones acerca de la violencia y del clima escolar, introduciendo la función social de la educación en el momento actual y las nuevas obligaciones de la institución escolar respecto al cumplimiento del Código de la Infancia y la Adolescencia, con relación a las responsabilidades parentales y pedagógicas, para luego dar una mirada a las tensiones que históricamente se han dado entre familia y escuela con el fin de entretejer las prácticas de exclusión que ocurren en la escuela, desde la mirada de los actores educativos.

El presente libro, cruza los recorridos teóricos y conceptuales con las miradas recogidas en el proceso de indagación, de manera que hemos incorporado los discursos de quienes nos enriquecieron con su sensibilidad, disposición y saber, con nuestras teorías y puntos de vista, resultado también de la experiencia.

Es fundamental, a la hora de analizar el fenómeno de la violencia escolar, revisar no solo las representaciones sociales de los maestros/maestras, de los padres y madres, sino también nuestras propias representaciones. Nos referimos a las representaciones como a una particular manera de pensar e interpretar la realidad cotidiana de los individuos y grupos que permite fijar una posición en relación con situaciones, objetos y comunicaciones. Teóricamente, asumimos las relaciones de violencia, las formas y los modos de actuar de los sujetos, de manera fundamental en el contexto escolar.

La investigación se inició en el primer semestre de 2009, en cinco colegios de Bogotá, de diferentes localidades del Distrito Capital. El proceso de investigación se realizó mediante la aplicación del modelo NES (ver anexo), el cual nos permitió interactuar con grupos de personas de manera voluntaria, para hablar sobre la violencia escolar. En cada sesión se buscó que los participantes exploraran la violencia escolar desde su propia subjetividad. 
Agradecemos a la comunidad educativa: maestros/maestras, directivos, padres y madres, su colaboración, compromiso y entusiasmo, sin los cuales no hubiésemos podido llegar a los resultados que hoy entregamos. 


\section{Función social de la educación}

A partir de la década de los noventa, dos hechos fundamentales redireccionan la función social de la educación en el mundo de occidente. El primero, la Conferencia Mundial sobre Educación para Todos, realizada en Jomtien, Tailandia, en 1990, en donde se definieron las bases de las nuevas funciones sociales de la educación a portas de comenzar el nuevo siglo.

Allí se revalorizó la necesidad de "adquirir conocimientos útiles con objeto de mejorar la calidad de vida, o aprender a aprender". (Conferencia Mundial sobre Educación para Todos, marzo de 1990: 7)

La necesidad de universalizar la educación básica, y la satisfacción de las necesidades básicas de aprendizaje de niños, niñas, jóvenes y adultos "para que los seres humanos puedan sobrevivir, desarrollar plenamente sus capacidades, vivir y trabajar con dignidad, participar plenamente en el desarrollo, mejorar la calidad de su vida, tomar decisiones fundamentadas y continuar aprendiendo," aduciendo que el verdadero desarrollo de los individuos y de la sociedad se apoya en la posibilidad de comprender y desarrollar conocimientos útiles, obtener capacidad de raciocinio, aptitudes y valores. (Marzo de 1990: 8)

El segundo, el informe de la Comisión Internacional sobre la Educación para el Siglo XXI presentado a la UNESCO en 1996, el cual fue presidido por Jacques Delors y titulado, La educación encierra un tesoro.

En este informe se asume la educación como la utopía necesaria para lograr el progreso social cifrado en la humanización de las relaciones sociales: "Frente a los numerosos desafíos del porvenir, la educación constituye un instrumento indispensable para que la humanidad pueda progresar hacia los ideales de paz, libertad y justicia social", sustenta la educación como proceso realizable a lo largo de la vida el cual se apoya en cuatro pilares fundamentales: "aprender a conocer, aprender a hacer, aprender a vivir juntos y aprender a ser". (Delors, Jacques, 1996: 9, 34 )

Este enfoque ético propone la función social de la educación en la construcción de relaciones sociales justas, libres, pacíficas, que permitan la cohesión y 
el establecimiento de vínculos sociales, fortaleciendo la equidad, ampliando la cobertura, reconociendo las diferentes formas de aprendizaje y controlando la exclusión social.

Entre estos dos acontecimientos de 1990 y 1996, se expidió en Colombia la Ley General de Educación, Ley 115 de 1994, la cual desarrolló el derecho a la educación contemplado en la Constitución Política de 1991. En dicha Constitución se definió la educación como "derecho de la persona" sin definir qué tipo de derecho y, a continuación, de manera ambigua, se le dio el carácter de "servicio público". En 2003, una visita de la relatora especial para el derecho especial a la educación de la Comisión de Derechos Humanos de las Nacionales Unidas, en su informe señala:

[...] El doble estatus de la educación en la legislación colombiana -pública y privada, gratuita y comprada- ha creado mucha confusión. Además, las políticas educativas del Gobierno debilitan el derecho a la educación por la falta de la garantía de la educación pública gratuita para la niñez en edad de escolarización obligatoria, por lo menos. La Relatora Especial estima importante destacar, como lo hace en cada informe anual, la diferencia entre la educación como mercancía y la educación como derecho humano. La ampliación de la compra-venta de la educación puede mejorar las estadísticas educativas, pero si el acceso depende del pago, no existe como un derecho humano. Los cambios recientes hacia la privatización arriesgan la educación como bien público y la escolarización como servicio público. Las protestas que reclaman la reformulación de políticas gubernamentales y las movilizaciones por los servicios públicos dejaron al descubierto la ausencia de una política y una práctica gubernamental que garanticen el derecho a la educación y la protección de los derechos humanos en la educación, a pesar de la normativa vigente. (Tomasevski: 2004)

La principal conclusión de dicho informe es que "Colombia carece de una estrategia educativa basada en los derechos humanos". (Tomasevski: 2004)

Para Martínez Boom, la educación es un servicio público que cumple una función social acorde con las necesidades e intereses de las personas, de la familia y de la sociedad. Este autor manifiesta que,

[...] la función social asignada a la educación se refiere al crecimiento económico, la competitividad, la formación para el trabajo y la capacitación para el desarrollo tecnológico. Estas funciones sociales priman sobre las denominadas funciones individuales asociadas a la función de socializar, transmitir la cultura y desarrollar la personalidad. (Martínez Boom, 2004: 306). 
En estas funciones hay un sesgo pragmático en la concepción de la educación al orientarla funcionalmente, casi que exclusivamente a la inserción económica del sujeto: crecimiento económico, competitividad, formación para el trabajo y capacitación para el desarrollo tecnológico, dejando en lugar secundario la formación integral en el plano de la cultura y la convivencia. Es decir, que la función de la inserción social y cultural del sujeto es la que está fallando.

Situación diferente a las sociedades que van más allá y consideran a la educación como servicio público y no como derecho fundamental. Aunque Colombia suscribió y ratificó en 1968, el Pacto Internacional de Derechos Económicos, Sociales y Culturales, más de cuatro décadas después, la educación no es aún ni gratuita ni universalizada, derecho que reconoce como obligatorio hasta el ciclo básico, es decir hasta noveno grado.

No obstante no podemos desconocer que dentro de los fines educativos propuestos en la Ley General de Educación está la formación en el respeto a la vida y a los demás derechos humanos, a la paz, a los principios democráticos y de convivencia, pluralismo, justicia, solidaridad y equidad, así como en el ejercicio de la tolerancia y de la libertad, en consonancia con las tendencias mundiales de la educación del siglo XXI, siendo éstos los aspectos que podrían contrarrestar las múltiples manifestaciones de violencia en el ámbito escolar. Hay pues, en las normas aspectos que están por desarrollarse en todo su potencial.

\section{Nuevas obligaciones de las instituciones educativas. Código de Infancia y Adolescencia}

Las instituciones educativas en Colombia, adquirieron otro tipo de obligaciones provenientes del Código de Infancia y Adolescencia, establecido mediante la Ley 1098 de 2006: obligaciones especiales, obligaciones éticas fundamentales, obligaciones complementarias y prohibición de sanciones crueles, humillantes o degradantes.

Las obligaciones especiales desarrollan algunos elementos de los fines propuestos en la Ley General de Educación sobre todo en lo pertinente al pleno desarrollo de la personalidad. Por ejemplo, la Ley General propone como fin educativo "el pleno desarrollo de la personalidad sin más limitaciones que las que le imponen los derechos de los demás" (Congreso de la República, Ley 115, Artículo 5, febrero de 1994) y el Código de Infancia y Adolescencia, retoma este fin, como una obligación especial de las instituciones educativas en cuanto, se les impone 
[...] respetar en toda circunstancia la dignidad de los miembros de la comunidad educativa; estimular las manifestaciones e inclinaciones culturales de los niños, niñas y adolescentes, y promover su producción artística, científica y tecnológica; y evitar cualquier conducta discriminatoria por razones de sexo, etnia, credo, condición socioeconómica o cualquier otra que afecte el ejercicio de sus derechos. (Congreso de la República, Ley 1098, Artículo 42, 2006).

El Código hace énfasis en este apartado en el respeto a la dignidad de todos los que conforman la comunidad educativa y un llamado a la inclusión social evitando toda discriminación.

En cuanto a las obligaciones éticas fundamentales, el Código propone garantizar a los niños, niñas y adolescentes el pleno respeto a su dignidad, vida, integridad física y moral dentro de la convivencia escolar, a través de: 1. Formar a los niños, niñas y adolescentes en el respeto por los valores fundamentales de la dignidad humana, los derechos humanos, la aceptación, la tolerancia hacia las diferencias entre personas. Para ello, deberán inculcar un trato respetuoso y considerado hacia los demás, especialmente hacia quienes presentan discapacidades, especial vulnerabilidad o capacidades sobresalientes, 2. Proteger eficazmente a los niños, niñas y adolescentes contra toda forma de maltrato, agresión física o sicológica, humillación, discriminación o burla de parte de los demás compañeros y de los profesores, 3. Establecer en sus reglamentos los mecanismos adecuados de carácter disuasivo, correctivo y reeducativo para impedir la agresión física o psicológica, los comportamientos de burla, desprecio y humillación hacia niños y adolescentes con dificultades en el aprendizaje, en el lenguaje o hacia niños y adolescentes con capacidades sobresalientes o especiales. En esencia el Código propone controlar toda manifestación de violencia en el espacio escolar. (Congreso de la República, Ley 1098, Artículo 43)

En la medida que esta obligación ética fundamental del Código, considera como valor fundamental la dignidad humana y el respeto a todo ser humano como principio ético, adquiere una dimensión diferente a lo propuesto en la Ley General de Educación en donde se contempló la ética como ejercicio docente a través del currículo, de los contenidos académicos, del ambiente, del comportamiento honesto de directivos, educadores, y personal administrativo, de la aplicación recta y justa de las normas de la institución, y de los demás mecanismos que contemplara el Proyecto Educativo Institucional- (Congreso de la República, Ley 115, Artículo 25, 1994) 
Podríamos decir que de una ética curricularizada en la Ley General de Educación, se avanzó hacia una ética relacional en el Código de Infancia y Adolescencia otorgando la mayor importancia al trato respetuoso, a la no discriminación, y a la protección contra toda forma de maltrato, buscando los mecanismos pedagógicos que impidan cualquier manifestación de expresiones de violencia física o psicológica en las instituciones educativas. Antes que enseñarla, la nueva norma propone vivirla y practicarla.

El Código agrega un nuevo campo de responsabilidades a las instituciones educativas a las que denomina obligaciones complementarias dirigidas a controlar algunas funciones específicas de la familia, a generar ambientes educativos no violentos y a denunciar situaciones de riesgo social de la población infanto- juvenil ante las autoridades competentes.

En cuanto al control del cumplimiento de algunas funciones familiares, contempla: a) comprobar la inscripción del registro civil de nacimiento, b) establecer el estado nutricional de los estudiantes, y situaciones de riesgo frente al maltrato, abandono, abuso sexual, violencia intrafamiliar, explotación económica y laboral, formas contemporáneas de servidumbre y esclavitud, incluidas las peores formas de trabajo infantil y c) comprobar la afiliación de los estudiantes a un régimen de salud. (Congreso de la República, Ley 1098, Artículo 44)

Consideramos que este tipo de funciones que asignan a un actor social, el poder de controlar a otro el cumplimiento de sus funciones, desequilibra las relaciones entre padres y maestros y agudiza los conflictos de rol entre unos y otros.

La pregunta que proponemos es ¿qué sucedería si por el contrario el Código atribuyera como obligación complementaria que la familia comprobara si el maestro desempeña o no su función pedagógica? Una y otra función reguladora se convertiría en un elemento de mayor conflicto social entre las dos instancias. Por ello consideramos excesivo asignar nuevas responsabilidades a las instituciones educativas que en lugar de acercar y armonizar a estos dos actores educativos que han estado distanciados históricamente, se agregue a uno de los dos, elementos de poder y de control que los hacen más distantes. ${ }^{1}$

1. Estudios históricos revelan que desde el surgimiento de la República ha existido un conflicto de roles entre padres y maestros que aún prevalece como lo sostiene Bárbara García Sánchez en "Consideraciones históricas sobre la relación familia y educación". 
En cuanto a las obligaciones complementarias dirigidas a generar ambientes educativos de convivencia no violenta, el código contempla: a) garantizar a los niños, niñas y adolescentes el pleno respeto a su dignidad, vida, integridad física y moral dentro de la convivencia escolar; b) proteger eficazmente a los niños, niñas y adolescentes contra toda forma de maltrato, agresión física o psicológica, humillación, discriminación o burla de parte de los demás compañeros o profesores; c) establecer en sus reglamentos los mecanismos adecuados de carácter disuasivo, correctivo y reeducativo para impedir la agresión física o psicológica, los comportamientos de burla, desprecio y humillación hacia los niños, niñas y adolescentes con dificultades de aprendizaje, en el lenguaje o hacia niños o adolescentes con capacidades sobresalientes o especiales; d) prevenir el tráfico y consumo de todo tipo de sustancias psicoactivas que producen dependencia dentro de las instalaciones educativas y solicitar a las autoridades competentes acciones efectivas contra el tráfico, venta y consumo alrededor de las instalaciones educativas; e) coordinar los apoyos pedagógicos, terapéuticos y tecnológicos necesarios para el acceso y la integración educativa del niño, niña o adolescente con discapacidad. (Congreso de la República, Ley 1098)

El sentido de estas obligaciones está en garantizar ambientes educativos libres de violencia, previniendo las manifestaciones de todo tipo de maltrato y garantizando las normas necesarias para la convivencia.

Respecto a otras obligaciones complementarias dirigidas a denunciar situaciones de riesgo social de la población infantil y juvenil, el Código dispone que las instituciones educativas deben reportar a las autoridades competentes, las situaciones de abuso, maltrato o peores formas de trabajo infantil detectadas en niños, niñas y adolescentes. Consideramos ésta, como una nueva función social de denuncia que ayuda a controlar el maltrato infantil y que ha sido ejercida en mayor medida a través de las Comisarías de Familia.

Pero en principio, la función primordial de la educación debe ser la formación a través de pedagogías que permitan verdaderos aprendizajes y no la denuncia, mecanismo que se convierte en evasiva cuando los profesores están saturados de obligaciones y de un número elevado de estudiantes y en esta acción de denuncia, queda reducido el trabajo formativo, el trabajo pedagógico y el trabajo de rehabilitación.

Un ejemplo resultado de esta investigación es revelador: en el trabajo de campo en la localidad de Fontibón, nos encontramos con una institución edu- 
cativa de alta conflictividad y en verdadera emergencia social, que tenía entre su personal estudiantil cincuenta estudiantes reinsertados de autodefensas y guerrillas, sin que la comunidad lo supiera. Además, bajo la tutela del ICBF, asistía un grupo en conflicto con la ley, de una institución de niños y jóvenes infractores de la localidad.

Nos preguntamos: ¿prepararon a la institución y a los maestros para participar de un programa de esta naturaleza? ¿Este tipo de convivencia con niños y adolescentes infractores, muchas veces de alta peligrosidad, coloca en riesgo al resto de la comunidad? La institución educativa, que no tenía los recursos ni las instalaciones ni el personal especializado para atender, además de las innumerables situaciones que "normalmente" debía afrontar, tales como enfrentamiento entre barras, pandillas, el micro-tráfico y el asedio de la delincuencia de la localidad sobre el plantel, entre otras, tenía además que afrontar estas situaciones convergentes. Podríamos decir que parte de la situación de emergencia que nuestra investigación encontró en dicho plantel se había agravado con la improvisación de estos programas.

Finalmente, en cuanto a la prohibición de sanciones crueles, humillantes o degradantes, en los espacios escolares, el Código contempla que los directores y educadores de los centros públicos o privados de educación formal, no formal e informal, no podrán imponer sanciones que conlleven maltrato físico o psicológico de los estudiantes a su cargo, o adoptar medidas que de alguna manera afecten su dignidad.

Así mismo, queda prohibida su inclusión bajo cualquier modalidad, en los manuales de convivencia escolar. (Congreso de la República, Ley 1098, Artículo 45)

Con esta prohibición, se coloca radicalmente límite al uso del castigo en cualquiera de sus formas en el espacio escolar. Los educadores deben tener conciencia de que la Ley es explícita en su prohibición cuando en el Artículo 18 dice:

\section{[...] Para los efectos de este Código, se entiende por maltrato infantil toda forma de perjuicio, castigo, humillación o abuso físico o psicológico, descui- do, omisión o trato negligente, malos tratos o explotación sexual, incluidos los actos sexuales abusivos y la violación y en general toda forma de vio- lencia o agresión sobre el niño, la niña o el adolescente por parte de sus padres, representantes legales o cualquier otra persona. (Congreso de la República, Ley 1098)}

Donde indudablemente se incluye el personal docente de las instituciones educativas. 
El sistema educativo deberá adaptarse a los cambios jurídicos que se vienen dando en el mundo desde 1989, fecha en la que Colombia suscribió la Convención sobre los Derechos del Niño. A partir de este momento según los expertos, se inició jurídicamente, un cambio de paradigma que abre una etapa a nivel internacional sobre el tema de la responsabilidad penal juvenil. Hemos pasado del llamado modelo tutelar que es considerado como un híbrido entre paternalista y represivo que, sin garantizar los derechos del imputado, lo consideraba inimputable penalmente, pero lo sancionaba fácilmente a penas con pérdida de la libertad sin garantías procesales. Hoy, es sujeto de todos sus derechos y hemos pasado al modelo de la llamada "doctrina de la protección integral", caracterizada así por la Oficina de la Naciones Unidas para la Droga y el Delito, UNODC:

[...] La doctrina de la protección integral, que viene inspirando las reformas a los sistemas de justicia juvenil en todo el mundo desde el año 1989, y que es el modelo adoptado por la Convención sobre los Derechos del Niño, se caracteriza por poner un equilibrio entre lo judicial y lo educativo, brindándole a los adolescentes las mismas garantías procesales que los adultos (y otras tantas más), pero con la necesaria orientación educativa y pedagógica en respuesta de la infracción cometida por el adolescente. El modelo preconiza la responsabilidad del adolescente por los actos que cometa que constituyan delitos. Empero esta responsabilidad debe ser coherente con su especial situación de persona en formación, para no perjudicar su desarrollo. (Oficina de las Naciones Unidas Contra la Droga y el Delito, 2004: 1).

De acuerdo con ello, el Código de Infancia y Adolescencia comparte la función social de humanización de las relaciones sociales en la escuela controlando toda forma de violencia, de marginación y exclusión social en el mismo sentido del Informe sobre la Educación para el Siglo XXI, suscrito por Jacques Delors. Pero además es un claro instrumento para controlar, prevenir, intervenir y denunciar las manifestaciones de violencia al interior de las instituciones educativas y del ámbito familiar. No cabe duda que el sistema educativo está viviendo una transición fundamental en la que debe adaptar su política, sus instrumentos administrativos y sus estrategias pedagógicas e incluso su infraestructura. Finalmente nos preguntamos si los profesores y directivos han recibido formación para asumir estas nuevas funciones sociales y si las instituciones educativas cuentan con las condiciones necesarias en personal, recursos físicos, programas y dispositivos pedagógicos para que esto se lleve a cabo. 


\section{La violencia escolar en Bogotá desde la mirada de los maestros}

Al presentar el resultado del escenario maestro, queremos propiciar la reflexión sobre un tema que no ha sido muy trabajado en nuestro contexto y que amerita ser tratado. Descubrir al maestro es una tarea difícil, implica revisar nuestras representaciones del personaje, de nosotros mismos como profesores investigadores, y entender sus anhelos, y frustraciones.

No pretendemos dar la idea que el estudio presenta un panorama completo sobre la violencia vista por los maestros en Bogotá, pero sí avanzar en su mirada de lo que ocurre en la escuela, en el ámbito de sus apreciaciones sobre la violencia, sobre el clima escolar y sobre su nivel de satisfacción o desencanto del ejercicio docente.

Centrarnos en la mirada del maestro significa mirar el conjunto de actores del medio escolar, a través de su percepción, así como los factores interpersonales que dan lugar a situaciones de violencia. Se trata de percibirlos, analizarlos, tal como son interiorizados y representados por el maestro.

Reconocemos así el papel activo y protagónico que ejerce el maestro en el manejo y resolución de los conflictos que suceden en el ámbito escolar. Reconocemos que el maestro es también sujeto de violencia, que puede ser víctima de ella, pero que también puede propiciarla.

La violencia no es un fenómeno contemporáneo, hoy se hace más visible, por las condiciones mismas que vive la institución educativa: maestros con múltiples responsabilidades, poca motivación, escaso tiempo para intervenir en las diferentes problemáticas escolares, activismo exagerado de parte de estos y de los directivos, situaciones de bienestar laboral y de remuneración poco motivadoras; niños inmersos de manera temprana en las dinámicas del mundo actual: drogas, alcohol, sexo, delincuencia, ausentismo escolar; de manera que se puede afirmar que al ser la escuela colombiana, resultado de un particular proceso de 
modernización, no ha escapado a las consecuencias que ha dejado la violencia política y social que ha vivido el país durante décadas.

De la misma manera como se ha indagado la mirada de la familia, sobre la violencia escolar, la mirada del maestro propone validar un modelo metodológico de carácter cualitativo planteado desde la micro sociología. ${ }^{2}$

El modelo utiliza un enfoque participativo que integra la descripción y la comprensión de la realidad objeto de estudio, a través de conversatorios con los participantes. El grupo focal y la entrevista, nos han facilitado la recuperación de los discursos individuales y colectivos de los actores. ${ }^{3}$

El trabajo se realizó en horarios fuera de clase, en espacios libres de los profesores, con su participación voluntaria. En cada institución se tuvo además, la posibilidad de entrevistar a directivos docentes, situación que nos permitió encontrar elementos comunes con los aportados por los maestros. En nuestro caso, conocer las problemáticas individuales y sociales vistas por los maestros, y los imaginarios que comparte el grupo sobre la violencia en la escuela, son elementos que permiten avanzar en la comprensión de esta realidad.

Así mismo, en el escenario maestro, al igual que en los otros escenarios, miramos la violencia en el contexto de las micro violencias (violencias impulsivas o difusas) que se suceden en la vida cotidiana y que son el resultado de conflictos individuales o grupales y nos referimos concretamente al maltrato, como una forma de relación y de trato inadecuado que puede manifestarse de diferentes maneras: maltrato físico, psicológico o verbal.

El encuentro con los maestros, nos exigió además de conversaciones informales, reflexiones acerca de la importancia del proyecto, compromisos del equipo investigador, con relación a la organización de jornadas pedagógicas y presentación de resultados finales.

El número de maestros participantes por cada colegio fue variable; para los grupos focales contamos con grupos de ocho a doce docentes por colegio /sesión y las entrevistas se hicieron por pares o individuales, aprovechando también la participación de coordinadores y rectores. A partir de la segunda sesión la

2. El modelo original (NEF). Núcleos de Educación Familiar fue aplicado en la prevención de violencias difusas en contextos educativos.

3. Ver libro Núcleos de Educación Social de esta misma colección. 
participación fue voluntaria, situación que generó un clima de confidencialidad y respeto mutuo. Nos proponemos presentar los resultados encontrados en tres aspectos: Cómo se percibe el maestro y cómo llega a la docencia. Cuáles son los conceptos que ha elaborado sobre la violencia en la escuela y cómo percibe el clima escolar.

\section{La mirada del maestro sobre sí mismo. Su historia}

Al tratar de comprender algo nos acercamos a ello con ciertas predisposiciones y significados previos

Gadamer, $\boldsymbol{H}$.

Se ha indagado la violencia entre pares: niños y adolescentes. Pocos estudios han analizado al maestro y su mirada sobre la violencia. Este trabajo tiene su origen en la necesidad de comprender el tipo de relaciones que se establecen entre los actores educativos y, sobre todo, en la mirada que el maestro tiene respecto a la violencia referida al maltrato como una forma de relacionarse de manera impropia. Lo consideramos importante por cuanto permite vislumbrar la manera como se enfrentan los problemas escolares por parte del docente y su incidencia en la relación pedagógica y en la adquisición de conductas, actitudes y valores.

Por otra parte, se ha convertido en lugar común afirmar que la violencia viene de la familia, del entorno que rodea a las niñas, niños y adolescentes, de la sociedad; que en la escuela no pasa nada o muy poco. La aproximación que hagamos sobre la violencia en la institución educativa desde la mirada del maestro, permitirá reunir algunos elementos en el sentido de definir si en realidad en la escuela no pasa nada o si por el contrario allí, como lugar de encuentro de diversas culturas, se generan conflictos y confrontaciones de manera cotidiana. Además, permite aventurar la hipótesis que el acto educativo es productor de cierto tipo de violencia y que en efecto todos los actores educativos viven la violencia de diferente forma.

Nos referimos concretamente al maltrato, como una forma de relación y de trato inapropiado que puede manifestarse de diferentes maneras: maltrato físico, psicológico o verbal.

Para develar la mirada del maestro nos centramos en las representaciones que éste elabora, a partir de las manifestaciones de violencia que percibe, que fo- 
menta, o de las que es víctima. Tales representaciones definen una manera de ser y actuar en la resolución de conflictos que se viven en la institución educativa.

Nos referimos a las representaciones como a una particular manera de pensar e interpretar la realidad cotidiana de los individuos y grupos, lo que permite fijar una posición en relación con situaciones, objetos y comunicaciones que les compete. (Jodelet, 1984: 473).

Una de las formas de hacer visibles las representaciones sociales la constituyen las prácticas que realizan en su cotidianidad los maestros; en ellas, se expresan las ideas, los conceptos y los modos de ver del maestro frente a sus estudiantes, frente a colegas, y frente a ellos mismos.

Las prácticas son, a la vez, "actos individuales y colectivos que simultáneamente delimitan y definen a cada ser humano, es decir, aunque siempre son hechos individuales se van reconociendo como repertorios colectivos que construyen cultura. La comprensión de la práctica como hecho cultural, nos remite al campo educativo desde diferentes perspectivas, entre ellas la práctica de los actores involucrados en el proceso educativo, en este caso particular, la práctica docente involucra el conjunto infinito de prácticas que ejerce el docente que se dedica a la enseñanza. (Ortiz et. al., 2008: 27)

En este sentido podemos afirmar que las prácticas dan cuenta de las representaciones sociales, por lo tanto, interrogarnos sobre la mirada del maestro frente a la violencia escolar, es reconocer las representaciones sociales que le dan sentido a las formas de actuar y de encarar las diferentes situaciones de maltrato.

Desde esta perspectiva parece claro indagar las representaciones sociales que construyen los maestros sobre la violencia, de manera particular, sobre lo que ellos creen que es la violencia en la escuela, sus características y su sentido.

\section{El maestro sujeto de reflexión}

Los maestros que hemos interrogado en nuestra investigación, en las cinco localidades, pertenecen al sector público del Distrito Capital. El 80\% son maestras, y buena parte de ellas viene de diferentes regiones del país. La gran mayoría no llegó a la docencia por elección propia sino que se dieron una serie de circunstancias que facilitaron su ingreso. 
El haber contado en su pueblo con una Escuela Normal, o tener en la familia miembros en la docencia, proporcionaron la incorporación al medio educativo. El porcentaje con experiencia de más de 15 años es elevado, de manera que la mayoría son personas que están entre 40 y 50 años. Un porcentaje pequeño corresponde a maestras y maestros más jóvenes.

En general, los maestros perciben su trabajo desde el ámbito de la enseñanza y la privilegian, aunque su quehacer esté centrado en procesos, actividades, y situaciones que debe resolver no sólo en el ámbito cognitivo, sino también en el plano valorativo y en el manejo de relaciones e interacciones que se dan en el espacio escolar.

Esta situación tiene sus consecuencias, ya que para muchos de ellos, atender problemáticas diferentes al ejercicio de la enseñanza se considera, fuera de su responsabilidad y afirman además que les quita tiempo y que no están preparados para solucionarlas.

\section{Sentido de pertenencia y compromiso}

En el grupo de maestros entrevistados encontramos un conjunto de ellos que resalta su amor a la profesión, su sentido de pertenencia y su compromiso con la comunidad a la cual están ligados. Una de estas maestras lo expresa de la siguiente manera:

[...] Llevo ya más de veinte años en la docencia, ¿Por qué soy docente? Porque me agrada hacerlo, me siento feliz siendo docente. Desde que era muy niña siempre tuve la inquietud de ser docente y afortunadamente la vida me dio la oportunidad de serlo y por eso he procurado hacer las cosas de la mejor manera para llegar a las personas y sobretodo pensar en proporcionarles un beneficio para su vida futura. (Maestro 032, abril $17 \mathrm{de}$ 2009)

Algunos hacen referencia al sentido que le dan a la docencia y resaltan su compromiso y decisión de transformar los espacios de su influencia:

[...] Cuando me dijeron que me enviaban a ese colegio, a mí solo me importaba saber cómo iba a llegar, que transporte me serviría, no tenía ningún referente, estoy iniciando mi experiencia en este colegio, pero siempre es el amor por la pedagogía, por ser maestra, lo que me impulsa, porque sabemos que podemos transformar muchas cosas, darle esperanza a los 
niños, y a los jóvenes. He trabajado en décimo y once, también he trabajado sexto, séptimo y octavo y me gustaría trabajar con los niños, esa es mi meta. (Maestro 030, abril 17 de 2009)

Se resalta también el amor a la institución y la vocación de servicio. La experiencia en la institución es también formativa para los maestros. Es importante tenerla en cuenta, frente a la costumbre de buscar equivalencia entre la actuación de éstos y el perfil que norma su trabajo, sin tener en cuenta el contexto social e institucional en el cual actúan. El mensaje que el aula comunica al maestro cotidianamente, se opone o hace efectivo su actuar y su mirada acerca de las problemáticas que a diario vive. Así lo explica una maestra:

[...] Es aquí donde he encontrado el sentido de ser docente, porque es dónde yo veo niños más necesitados, una se entera de muchas situaciones y es importante conocerlas para no cometer errores. Yo siento que soy maestra por vocación, madrugo porque me gusta, lo hago con amor, siento que lo que yo pueda hacer por este colegio, le da sentido a mi vida, porque una quiere que su institución cada día sea mejor y sus estudiantes salgan adelante. (Maestro 011, febrero 6 de 2009)

El discurso de la vocación es un discurso de auto legitimación: la escolarización de los sujetos como misión para el maestro, fortalece la cohesión e identidad del grupo y la considera fundamental dado que ellos mismos son producto de tal escolarización.

Por otra parte aunque tienen alto reconocimiento de la institución educativa, los maestros poseen una baja consideración de su profesión, la imaginan

[...] una cuasi profesión, dado que la enseñanza comparte ciertas características típicas de las profesiones constituidas, tales como preparación académica, la posesión de un título que lo habilita y garantiza una exclusividad en la ocupación de ciertas funciones, un conjunto de reglas éticas, que conforman una deontología, etc.., sin embargo al contrario de lo que ocurre con las profesiones liberales clásicas, los docentes están sometidos a un control jerárquico, trabajan en grandes organizaciones, no eligen a sus 'clientes' y su carrera no depende de su rendimientos. (Dubet et. al., 2006: 131).

El trabajo en equipo es una característica que se resalta en los nuevos cambios que enfrenta el sistema educativo. Los maestros consideran que están entrando en esta cultura, no sólo con sus colegas sino también con sus estudiantes y que 
éstos logran entender su importancia. Para algunos, ya no es importante el momento de la nota o la aprobación en el caso de colegas, como la responsabilidad y compromiso de trabajo que se construye cuando hay equipo.

Un buen maestro promueve una mirada positiva de su quehacer y se convierte en ejemplo a seguir. Así lo expresa una maestra:

[...] Cuando estaba en cuarto de primaria tuve una excelente docente y fue cuando decidí que iba a ser docente, en quinto por la influencia de un profesor físico- matemático me decidí por la matemática. Terminé en la Normal Montessori, luego en la Universidad Pedagógica y más tarde en la Universidad del Bosque y aquí estoy. Después de veintisiete años, sigo con entusiasmo y apasionada por ella. (Maestro 033, abril 17 de 2009)

El entusiasmo y la pasión por lo que se hace, tienen implicación directa en los procesos educativos. Tal como lo señala Jurjo Torres "Trabajar como docente implica confiar en las posibilidades de aprendizaje del alumnado y transmitirle entusiasmo por las tareas que se le proponen, así como acerca de sus posibilidades de éxito. Saber comunicar entusiasmo y apasionamiento por la cultura y por aprender, son aspectos fundamentales de todo proceso educativo." (Torres, 2006: 85).

El colegaje y las buenas relaciones entre los maestros permite, en algunos colegios, que se pasen por alto las tensiones y la violencia cotidiana. Cuesta entender que en ambientes tan difíciles, los maestros puedan permanecer quince y veinte años sin pedir traslado.

\section{Las relaciones socio afectivas}

El tipo de relaciones que establecen maestros y estudiantes son fundamentales para el desarrollo armónico del trabajo. Es así como en el ejercicio docente, la forma como se construyen las relaciones con los estudiantes es un factor significativo, en la medida en que influyen en las actitudes que los estudiantes tienen hacia sí mismos, hacia los otros, el aprendizaje y el entorno cultural del que hacen parte. (Ortiz et. al., 2008: 111).

Los maestros expresan tener afecto por sus estudiantes, la situación se ve expresada en la siguiente frase:

[...] Les voy a comentar lo que dijo mi colega a otro profesor: Le presto mis hijos por este año, pero el año entrante me los devuelve; ella siente que 
esos estudiantes son sus hijos que han trabajado con ella y los ha formado y nosotras, más que atender su formación académica, atendemos su formación valorativa en sus relaciones con los otros. (Maestra 007, febrero 6 de 2009)

J. Torres afirma que durante mucho tiempo en el mundo de la educación sólo se prestaba atención explícita a las dimensiones intelectuales, olvidando que los sentimientos afectos y expectativas positivas son uno de los motores más importantes para movilizar e implicar a las personas. (Torres, 2006: 85).

En este sentido, podemos afirmar que las dimensiones socio-afectivas son de gran importancia, ya que mueven un alto porcentaje de los intercambios entre maestros y estudiantes. Estos intercambios de por sí definen la relación educativa que se establece en el ámbito escolar. "La escuela transmite conocimientos pero fracasa totalmente en el plano emocional". (Bettelheim: 32).

Cuando el maestro es indiferente a las situaciones que vive el estudiante, o niega las dificultades de comunicación con ellos, se genera una pérdida en el alcance afectivo de profesor-estudiante.

Ada, Abraham, llama la atención sobre la necesidad de interrogarse sobre:

[...] ¿Cómo ver claramente los estados afectivos caracterizados la mayor parte del tiempo por la mezcla y la confusión de sentimientos, la atracción o la repulsión, la indiferencia etc., cuando se es docente? ¿Acaso no se deben tener en cuenta estas cosas?...Poner entre paréntesis la afectividad es, en realidad, casi imposible a partir de cierto grado de sentimientos". En efecto, muchos factores intervienen para hacer más efectivo de lo que se cree el acto de comunicación pedagógica. (Abraham, 2000: 33).

\section{Identidad docente refundida, negación de la profesión}

Sin embargo, encontramos otro grupo de maestros, que tropiezan después de años de experiencia con dificultades de aceptación de la profesión que han escogido, llegaron a ella por casualidad o por falta de oportunidades en otras carreras, tienen un nivel de formación precario para el ejercicio de la docencia, con formaciones en tipos de bachillerato que no facilitan su desempeño, terminan aceptando su situación pero con una identidad refundida, negando su profesión o desempeñando funciones docentes de muy baja calidad, con cierto grado de resignación. Una maestra lo expresa así: 
[...] yo les cuento que estoy en la educación por chiripa, dentro de mis planes yo quería ser [...], siempre me gustó, pero yo no quería ser profesora. Tuve experiencias muy amargas como estudiante... yo no quería ser profesora ni por el chiras. (Maestro 026, abril 17 de 2011)

Otro maestro afirma después de una larga lista de trabajos:

[...] le soluciono todos sus problemas, plomería, electricidad, otros quehaceres domésticos, presto el servicio de trasporte, su seguridad es mi compromiso y por último soy docente de... (Maestro 014, febrero 6 de 2009)

En estos casos, el rechazo a la docencia se constituye en un factor de desmotivación frente a la labor docente, que se evidencia luego en pobres resultados de formación de sus estudiantes. Se afirma:

[...] En primer lugar lo que se transmite no puede separarse, como si fuera un objeto, de la persona que lo transmite: se trata de un saber interiorizado que está ligado a un ser que se comunica de la misma manera en que la vibración está ligada al aire, la temperatura al agua o el color al cuadro. (Abraham, 2000: 33).

Las condiciones laborales del maestro actual y su nivel de remuneración, constituyen otro de los problemas en la representación social que el maestro tiene de la docencia, de su nivel de satisfacción y en la mirada sobre sí mismo. Algunos trabajan en sitios extremos y le restan tiempo al trabajo en el sector público, ya que en los colegios privados les exigen condiciones de mayor responsabilidad. Otros logran organizar su doble jornada en sitios cercanos, pero lo que se puede vislumbrar es cierto desinterés por lo público y mayor dedicación a lo privado. Un maestro expresa así su situación:

[...] cuando me di cuenta que el colegio público quedaba cerca al colegio privado, salté en una pata, podía por lo menos abarcar un poco más de horario allá, que era un punto débil en esa contratación, podría trabajar por lo menos veinticuatro horas que es una carga suficiente...entonces yo llego con esa motivación de poder estar allá y acá para poder construir, primero que todo económicamente algo, porque en las categorías bajas con un solo salario, con un solo trabajo, no es suficiente. (Maestro 036, 22 de mayo de 2009)

El panorama presentado a lo largo de este aparte, muestra el ejercicio docente como algo vital para la mayoría de maestros, su grado de pertenencia e identidad, así como los juicios valorativos y su grado de satisfacción con la profesión, 
define de cierta manera, su actuar en los procesos de resolución de conflictos y en el manejo de las situaciones de maltrato que se dan en el espacio educativo.

Cada maestro pone en juego en su cotidianidad, no solo sus características individuales sino que debe hacer acopio de otras que le permitan hacer frente a las múltiples dificultades que enfrenta diariamente y que hacen parte de su quehacer. Su capacidad de innovar y su formación continua le facilitarán asumir con menos dificultades su tarea.

\section{Concepciones sobre la violencia}

Como fenómeno histórico la violencia se ha hecho presente siempre en el ámbito social y en la institución educativa no ha sido la excepción. Los orígenes de la violencia escolar en Colombia se podrían remontar al nacimiento de la escuela. No constituye en la actualidad un fenómeno contemporáneo, sino que se hace más visible y se manifiesta con mayor fuerza, por las condiciones mismas que vive la institución educativa: profesores con múltiples responsabilidades, poca motivación, escaso tiempo para intervenir en las problemáticas escolares, estudiantes inmersos a temprana edad, en situaciones del adulto: droga, alcohol, sexo.

Michel Foucault señala que la aparición de las escuelas en el siglo XVII, coincidió con la aparición de los establecimientos hospitalarios, las instituciones carcelarias y los cuarteles, y si bien son instituciones diferentes en sus características y funciones, guardan similitudes a tal punto que en la escuela en ocasiones, ocurren episodios de control disciplinario que se asemejan a situaciones de autoritarismo y represión de estas instituciones, ocasionadas por las características de violencia generadas por los diferentes actores educativos. (Foucault, 1986: 309)

El primer problema que encontramos en nuestra investigación, con los maestros es la dificultad de ellos para establecer diferencias entre expresiones como: violencia, agresividad, conflicto, maltrato, situación que conduce a que casi siempre se utilicen como sinónimos. Esta falta de diferenciación hace que los maestros, en algunas ocasiones, le den gran trascendencia a comportamientos que pueden ser resueltos fácilmente, o que en otras no le concedan la importancia que tienen o decidan ser indiferentes ante ellos. 


\section{La violencia: carga negativa de su enunciado}

Frente a la conceptualización de la violencia se percibe también entre los maestros entrevistados, enorme dificultad para expresarla y más aún para conceptuarla. La ambigüedad con que se enuncia es generalizada, pero existe un elemento común y es la carga negativa que denota su enunciado. (Gómez, 2005: 699)

En general, el profesor se refiere a ella como algo externo a su acontecer. Como: "la manera de transgredir al otro, afectar su ser, manipularlo y vulnerarlo tanto física como emocionalmente”. (Maestro 030, 24 de abril de 2009)

"Como una herramienta para solucionar problemas y, como una forma cultural de expresarse, de manifestarse y hacerse notar". (Entrevistas a maestros, abril de 2009)

"Como actos humanos que han impregnado todos los espacios de interacción de manera negativa". (Maestro 034, abril 24 de 2009)

A su vez, los investigadores definen la violencia en relación con el uso de la fuerza, la rudeza ejercida voluntariamente en detrimento de alguien. (Chesnais, 1981: 12)

O es expresada también como un estado de confrontación en la que se encuentran dos o más personas y de las cuales alguien sale afectada y agredida física o mentalmente. (Planella, 1998)

Las dificultades que presentan estos dos puntos de vista, favorecen la escasa claridad sobre la misma.

Peter Smith propone que la violencia en la escuela sea entendida como: El producto de actos intencionales y sistemáticos que se convierten en un daño o en una amenaza. (Smith, 2005)

Así, las conductas agresivas en la institución escolar, no se reducen a actos de violencia física sino que pueden convertirse en acciones constitutivas de abuso de poder por parte de adultos que son en general, más fuertes frente a otros más débiles, abusos que pueden ser verbales de exclusión o marginación a grupos o individuos.

Una profesora afirma: 
[...] La violencia también es comprendida como una predisposición a la agresión, se considera al niño incapaz de aceptar que el maestro le llame la atención, además de expresar con sus gestos una predisposición permanente a defenderse cuando alguien se le acerca. (Maestra 010, entrevista 4)

En este sentido, la violencia que se da en las aulas, se ha constituido en la cotidianidad entre los actores educativos: maestros y alumnos. Se acepta como algo normal, ya no causa extrañeza o asombro, al contrario, se acentúa convirtiéndose en una situación permanente.

En el transcurso hacia la modernidad afirma Durkheim, se destruyen y perturban relaciones, vínculos y las regulaciones de la sociedad tradicional, al mismo tiempo no se crean instituciones o espacios capaces de cohesionar lo social... el pensamiento moderno contribuye a este proceso de anomia, puesto que los valores y en sí todo el imaginario social que suscita, va desplazando las creencias tradicionales y los referentes simbólicos de autoridad por ídolos modernos inmortales de voluntades transgresoras, se abren espacios de entretenimiento y omnipotencia que brinda la tecnología, resultan nuevos valores sociales a seguir los cuales dan prioridad al bien material e individual. (Durkheim, 2008).

Se desprende de lo anterior, aceptar como normal ciertos comportamientos agresivos, como nuevos valores sociales incorporados a la cotidianidad.

\section{La violencia: ausencia de tolerancia}

Los comportamientos agresivos se traducen en falta de respeto y tolerancia. Así lo expresa una rectora:

[...] La violencia en la institución yo la percibo como esa falta de respeto por el otro, la falta de respeto por lo que hay, por lo que es de todos, la intolerancia, el no querer escuchar. (Maestra 019, 16 de marzo de 2009)

En la génesis de la violencia resulta esencial el sistema sociocultural, por lo tanto, ella expresa rasgos de la colectividad en donde germina. La violencia es y se realiza, tanto como un proceso social subjetivo (imaginarios, representaciones, significaciones sociales,) objetivo (conductas, usos, comportamientos, acciones), palpable (hechos, coyunturas,) y enmascarado (cultura, estructura), donde la valoración emocional de sus efectos visibles e invisibles pasan a formar parte del mismo proceso. (Maturana, 2008: 65) 
La violencia de acuerdo con lo anterior, se traduce en un modo de convivir, una forma y estilo de relacionarse con los demás que se conecta con las representaciones que de ella se construyan, con los comportamientos habituales y con la cultura en la cual se origina.

Las expresiones utilizadas por los profesores van ligadas a representaciones que sitúan el fenómeno de la violencia en la escuela, como algo connatural a los niños y jóvenes. Algunos profesores expresan no percibir conflictos como una manera de ocultar o afirmar que no pasa nada, que lo que ocurre no puede ser considerado como una forma de violencia.

Esta actitud corresponde al temor de posicionar la institución como violenta frente a la mirada exterior, o a posturas de acostumbramiento frente a las actitudes conflictivas de los actores escolares, situación que facilita la preservación de un estado de cosas. Pareciera que se elaboraran acuerdos inconscientes, dirigidos a preservar la continuidad de los beneficios que se reciben cuando se preserva el ideal institucional, frente a una realidad que se opondría a la ilusión de unidad expresada por el grupo. Es lo que Kaës denomina pacto de negación. (Kaës et. al., 1998).

En ese sentido, las actitudes de los estudiantes nada tendrían que ver con la institución escolar ni tampoco con los profesores, dando así la idea que todos los problemas que se originan al interior vienen de afuera, por diversas causas como las desigualdades que vive gran parte de la población estudiantil de sectores deprimidos, los problemas de la familia o la ausencia de valores. De esta manera, las responsabilidades de los demás actores educativos estarían excluidas.

Al respecto se señala que "La violencia atraviesa los otros fenómenos a los que califica pero los trasciende también. Esta distinción es particularmente importante porque hay una tendencia poderosísima a representarse cada uno de estos fenómenos en su modalidad violenta, la más visible”. (Del Barrio et. al., 2003: 66)

Para algunos investigadores, la violencia en ciertas circunstancias se justifica. Se le atribuye connotaciones positivas o negativas como las de "lícita o ilícita". Se trataría de una violencia positiva al lado de una cuestionada que pone en interrogación sus límites y sus alcances. (Miermont, 1987: 22)

También, se define la violencia como la causa de la agresión, quienes agreden serían violentos; la violencia se considera así, como una particularidad de la persona, la institución o el grupo que actúa en forma desmedida. (Guillote, 2003: 27) 
Esta consideración determina que si la persona tiene actitudes agresivas es porque es violenta.

Así, toda acción de la persona o del grupo, se convierte en un rasgo de personalidad y si la situación se repite por mínima que sea, ese rasgo de personalidad se resalta, para compararlo con otros que no poseen esa particularidad. Lo curioso es que algunos maestros comparten este punto de vista. El niño que agredió, la institución que tuvo una situación irregular, el grupo que tuvo un comportamiento inapropiado, puede convertirse de manera permanente para los observadores como violento. No en vano se escucha decir al profesor al observar un niño que corre en el patio de recreo y que empuja a otro, "ese niño es violento".

En todos los casos, cuando se trata de definir la violencia, pensamos en una fuerza intencional que se da a través de una relación social, pero también la vemos como un fenómeno social multi-relacional y multi-causal. Podríamos decir que la violencia es:

[...] Un fenómeno histórico cambiante en su significado social y en su manifestación subjetiva y objetiva, es en el presente concebida como el proceso al mismo tiempo globalizado y localizado que da cuenta del fenómeno en la perspectiva histórica, social y política en la que se vive”. (Roa, 2008: 64)

Estamos de acuerdo con Fernando Osorio, cuando postula que la violencia es una construcción social. (Osorio, 2008)

El concepto se construye a partir de una realidad que es violenta, y se traduce en un discurso que se implanta y que permite construir una imagen, algunas veces ajustada a la realidad social, en otras ocasiones depende de los imaginarios y representaciones sociales que se hayan construido, de acuerdo también con ciertos intereses. Por eso, lo que se expresa por violencia, depende mucho de los actores, de los intereses en juego, de las representaciones que se tengan y su solución dependerá también de los consensos, compromisos, decisiones que se pacten.

En la institución educativa, la violencia se ha visto siempre como el atributo del estudiante y la autoridad como el recurso del profesor, sentido que genera desacuerdos y serias dificultades porque se corre el peligro de asumir la autoridad como una medida de represión de la agresión, contrario a lo que realmente significa el término autoridad. Los fenómenos que ocurren en la realidad escolar, dependen de las significaciones que le atribuimos, lo que denominan configuraciones emergentes. (Varela, 1984) 


\section{La violencia como algo exterior a la institución educativa}

Así mismo, se destaca la percepción generalizada de que los conflictos en la escuela vienen de fuera: familia, medios de comunicación, condiciones socioeconómicas, conflicto armado; excluyendo la posibilidad de que las tensiones que se viven al interior, puedan tener su origen en el ambiente institucional. De esta manera, se libera la responsabilidad y el trabajo que debe hacer la institución y el equipo de profesores, como partícipes de una realidad y se pierden espacios de construcción de actitudes favorables a la convivencia.

Esta situación refuerza también la idea de ver la violencia como algo exterior a la acción del educador. Expresiones como: "La violencia escolar: es una violencia generalizada de la sociedad, es una forma de vida". (Entrevistas a maestros, abril de 2009)

"Nuestros colegios reciben toda la violencia de fuera. Somos los receptores de toda la frustración que hay afuera". (Maestro 025, 22 de mayo de 2009)

Estas expresiones refuerzan la idea de que no existe violencia en la escuela. Si bien, aceptamos que la familia es fuente de conflictos, muchos de ellos de mucha gravedad, y que muchas violencias en la familia se presentan justificadas por los padres, consideramos que aceptar que la escuela es también generadora de violencia, facilitaría encauzar acciones tendientes a disminuir los episodios que ocurren de manera cotidiana en la institución educativa.

Valdría la pena preguntarse, ¿cuál es el papel de lo cotidiano en la escuela ante la generación de actos violentos y ¿cuál es el papel de modelaje que ejercen los adultos en el ámbito educativo? Si aceptamos que la violencia tiene múltiples causas, no es posible excluir al alumno y colocarlo ajeno a los actos violentos, pero también a las posibilidades de intervenir y asumir un papel activo en dinámicas más positivas como un actor social que participa, que siente y que vive la realidad escolar.

Respecto al maestro y su relación con el alumno en situaciones de maltrato, es necesario tener en cuenta los consensos y los compromisos que florecen entre las partes, cuando no es la autoridad como recurso de poder representada en el maestro la que predomina, sino más bien, la cualidad que permite aceptar que alguien ayude a regular los actos, porque esa persona cuenta con reconocimiento y consideración en la forma como interactúa con los demás. 


\section{Los maestros en entornos violentos: Maestro como agente de cambio}

Un problema marcado en las instituciones es la acomodación a la violencia: Se esperaría que los maestros, conociendo después de varios años las instituciones, tuvieran elementos muy claros de cómo hacerle frente a estas situaciones. Una rectora se expresa así:

[...] El maestro tiene la costumbre de acomodarse a la situación, una se acomoda y se acostumbra, no genera acciones de cambio, para mejorar la situación. Porque nosotros somos también responsables de esa violencia, es un trabajo de grupo y, dónde no hay compromiso de todos es muy difícil, porque unos quieren construir mientras otros destruyen con su misma actitud de indiferencia... simplemente la indiferencia, que otros hagan pero yo no me meto en eso. (Maestra 010, marzo 6 de 2009)

Con frecuencia los maestros expresan esa preocupación. ¿Cómo cambiar si no todos asumen el reto? Sin embargo, es claro que existe de parte de la gran mayoría, conciencia de los problemas que se viven; y muchas veces, los maestros no actúan por temor a las amenazas que se pueden concretar a la salida del colegio, ya que sus lugares de vivienda no siempre se ubican en el mismo sector, en general viven en otros contextos y estratos.

\section{La violencia secreta en las instituciones}

La violencia en los colegios, va más allá de ser un fenómeno aislado, se presenta como algo cotidiano, repetitivo y constitutivo de la cultura escolar. "El orden institucional e impersonal de las reglas de la escuela, esconde en el fondo una violencia cotidiana y de igual forma se diluye la responsabilidad de los sujetos al 'actuar' en nombre de un mandato institucional”. (Gómez, 2005: 704)

Y como lo señala un maestro:

[...] Me veo obligado a aplicar correctivos, no me siento padre del alumno, pero lo hago en nombre de su formación y de la educación que deben recibir y también del buen comportamiento que deben tener y observar... cuando crecen, es cuando valoran lo que le enseñamos en este colegio. (Maestro 035, 6 de marzo de 2009)

La lógica de la normatividad institucional es la que prima en los diferentes tipos de interacción que se dan en la institución escolar, normatividad fuertemente arraigada en las costumbres. En ese sentido las violencias son relaciones que se 
articulan toman formas y figuras concretas en contextos históricamente situados. (Brawer, 2006: 48)

En los casos en que se da la desinstitucionalización de los medios, en grupos en donde los componentes de la estructura social no están bien arraigados se produce lo que Durkheim denomina la anomia o falta de norma. Para él, la anomia es un problema moral relacionado con el rompimiento o deterioro de los lazos sociales y el decaimiento de la solidaridad. También lo asocia con la transformación de las representaciones colectivas y de allí con el problema de regulación de expectativas y deseos. (Durkheim, 2008: 67).

Importante señalar que la violencia se oculta entre las paredes de la escuela, se mantiene en secreto, oculta, como un reflejo de la eficacia de los recursos institucionales para preservar lo que sucede. (Khaës et. al. 1998: 91)

Si bien la familia es una parte central en la formación de valores, la escuela sería en el desarrollo de un niño, la otra institución en la cual pasa la mayor parte del tiempo y en la que prosigue la formación de su personalidad, pero tampoco podemos decir con certeza lo que ocurre tras sus muros. (Gómez: 695)

\section{La violencia y las interacciones de poder y exclusión}

Resulta interesante analizar la emergencia de la violencia, entre otros, en espacios relacionales, en donde prevalecen las interacciones de poder, las actitudes discriminatorias y de exclusión social. Es desde este ámbito, donde se puede comprender las dinámicas de la violencia al permitir apreciar, como sus consecuencias pasan a consolidarse cultural y estructuralmente y así favorecer a sus propios círculos. (Maturana, 2008: 64)

En esos espacios relacionales, como la institución educativa, pareciera que se genera violencia por la carencia de oportunidades: "Los muchachos no tienen nada qué hacer, no se le brindan oportunidades y están todo el tiempo solos". (Maestro 010, 6 de marzo de 2009)

Cuando llegan al colegio tienen la carga de sus limitaciones, sus carencias y su soledad, y son fácil presa de la droga, de episodios de violencia. Otros, producto del desplazamiento, están marginados, no cuentan con redes sociales de apoyo y quedan a la merced de las circunstancias, que en general son adversas. En 
estas condiciones resultan ser fácil presa de la indiferencia, el rechazo, y no pocas veces de la exclusión.

La falta de entrenamiento en estrategias para intervenir en episodios de violencia en la escuela, hace que los maestros intenten resolver fallas de la educación familiar de manera adecuada o que, por el contrario, asuman actitudes autoritarias, sustituyendo de manera negativa las funciones parentales, y justificando su actitud con una aparente preocupación por los estudiantes y su formación.

Es necesario tener en cuenta que la diversidad de estructuras familiares que han surgido: padres separados con segundos vínculos, que conviven con los hijos de ambos, parejas separadas, o padres que por situaciones de orden económico están menos tiempo en el hogar, han generado transformaciones en la forma de desempeñarse como padres; ya no son ellos quienes ponen límites a los comportamientos disruptivos, cumplimiento de normas y responsabilidades sino que es el maestro y la escuela quien asume tales responsabilidades y, en muchas ocasiones, no están preparados para enfrentarlas.

En general, las dimensiones asignadas a la violencia son minimizadas. Si bien hay una tácita aceptación de la gravedad del problema, los maestros afirman que ha disminuido respecto al pasado y que son los medios quienes engrandecen los fenómenos de violencia. Esta mirada influiría en la escasa importancia que le dan a los procesos investigativos en el campo de la violencia, o en la escasa participación en proyectos destinados a enfrentar el fenómeno de la violencia en la institución educativa.

\section{Contextos que influyen en la violencia}

La percepción generalizada entre los maestros es que la violencia viene de fuera: familia, contexto barrial, medios de comunicación, conflicto armado, situación económica, Algunas apreciaciones dan cuenta de esta percepción:

[...] He apreciado que entre nuestros jóvenes de décimo y undécimo y sus padres existen grandes diferencias: porque los jóvenes piensan de una manera y los padres de otra. No hay dialogo ni punto de encuentro entre las dos partes. Es más grave entre los jóvenes de quinto, sexto y séptimo. La visión que tienen de sus padres es de abastecedores y si se suma a esto, el desempleo y la dificultad que tiene muchos padres para darle a sus hijos lo básico, la situación de la familia se vuelve insostenible y los episodios de violencia no se dejan esperar. (Maestro 032, 22 de mayo de 2009) 
Otra maestra argumenta refiriéndose a los medios de comunicación:

[...] Yo pienso que la violencia en los jóvenes es causada por los mismos programas de televisión. En estos programas siempre hay violencia, incluso en las franjas para niños. Creen que así se manejan las cosas y en las casas hay mucha intolerancia". (Maestro 010, 6 de marzo de 2009)

La familia es de alguna manera descalificada en el ejercicio de su rol y se vislumbra opuesta al maestro generando distanciamiento. La mayoría de maestros tienen una representación pobre de los padres y argumentan que no tienen control sobre sus hijos. Señalan también el abandono al cual los exponen y se consideran como elementos generadores de violencia. Falta dialogo, control y autoridad.

Mirada la situación desde esta perspectiva, la institución escolar no tiene nada que hacer en la construcción de espacios de convivencia. El maestro se libera de su responsabilidad y los espacios de construcción de valores como el respeto y la tolerancia no tienen cabida en el espacio educativo

Estamos de acuerdo con la mirada de Silvina Chemen quien afirma que:

[...] A pesar de la desilusión de algunos, la incredulidad de otros, la desesperación de muchos; a pesar de la angustia que nos provoca a todos los que tenemos que ver con la escuela, ya seamos docentes, directivos, asesores, padres o alumnos, la sensación de no poder comprender acabadamente por qué el comportamiento humano está tan teñido de violencia, a pesar de una realidad aparentemente inmodificable, sostenemos que desde la escuela hay mucho por hacer frente a la violencia. (Chemen, 2001: 157)

\section{Sentido de la violencia}

En cuanto a la comprensión de si un acto es violento o no, vale la pena centrarse en el sentido que se le da al mismo, es decir, entender lo que lo origina y justifica. Así, un acto violento podría estar ocultando una razón o sentido, un significado, una causa o síntoma, o estar situado en un plano más sofisticado que sería violentar al otro para conocer su reacción. El mecanismo que se adopte para resolver ese problema dependerá mucho de la mirada que se tenga en su resolución.

En este aspecto con mucha frecuencia en los espacios educativos, se observa la poca atención que profesores y estudiantes le confieren al sentido que le dan a sus actos, un acto que parece violento para el profesor pudo pasar desapercibi- 
do para el estudiante, en otros momentos, los temores, la inseguridad que causa la violencia, hace que el sentimiento frente a ella prevalezca sobre la realidad de la situación. Aparecen en este caso, los juicios de valor, las interpretaciones y hasta las creencias.

En últimas, es el sentido que le damos a los actos, lo que denota su gravedad o levedad, y es aquí, donde la interacción se constituye en factor definitivo para su comprensión.

Pero también existen otras miradas sobre el sentido que se le da a la violencia, las cuales tendrían que ver con un defecto o una dificultad para comunicarse con los demás, y que sería el resultado de carencias educativas. Sin embargo, en la escuela a veces, la dificultad de comunicación de los estudiantes es el resultado de privaciones, rechazos, temores que el profesor debe tratar de descubrir para darle el sentido adecuado. En otros casos la violencia es vista como propia del ser humano y como tal, esta violencia es la que fundaría el vínculo social.

\section{Papel del maestro frente a la violencia}

Respecto al papel del maestro frente a la violencia podemos señalar dos grupos con contradicciones manifiestas: por un lado, los que expresan su buena disposición al diálogo y la reflexión como mecanismos para resolver los conflictos en el aula, pero por otro, aquellos que afirman no tener tiempo, ni los instrumentos necesarios para enfrentarla, y asumen su rol de manera secundaria. Además la actitud con la que enfrentan los conflictos con los alumnos o con sus colegas, no constituye un patrón de comportamiento a seguir: indiferencia, exclusión o maltrato, son elementos que los estudiantes interiorizan y lo toman como modelo para reproducirlo en sus relaciones con los otros.

Este grupo se caracteriza por ser pasivo frente a la violencia, con pocos recursos pedagógicos para enfrentar las acciones necesarias y depende en alto grado de las orientaciones de sus directivos, además, sitúa las causas de la violencia externas a su actuar: familia, sociedad, condiciones del país.

En este aspecto es notoria la precariedad de la formación que reciben los maestros en su proceso de formación pedagógica, para enfrentar las situaciones de conflicto en la escuela. Por esto, es común que dejen la responsabilidad en manos de los orientadores escolares generalmente uno o dos por institución, que por otra parte, tienen un contacto escaso con los alumnos y están destinados a realizar multiplicidad de tareas muchas veces lejanas de las de orientación. 
El otro grupo, minoritario, por lo demás, le da gran importancia a los procesos educativos y a la capacidad de éstos para generar transformaciones, es dinámico, realiza intentos en el aula para mejorar el manejo de los conflictos, está dispuesto a escuchar y señala algunas alternativas como la generación y gestión de manuales de convivencia, concertados con los estudiantes, el acercamiento a la familia, la reflexión permanente pero al no generar estrategias concretas de acción, su actuar se reduce a declaraciones de principios que pocas veces se hacen realidad.

La organización escolar, el activismo y las relaciones disfuncionales entre los grupos de docentes, en algunas de estas instituciones, contribuyen a que buenos proyectos y buen equipo de trabajo se desanime en su intento y se genere frustración y angustia entre los maestros.

\section{El manejo del conflicto}

Con relación al manejo que el maestro le da a los conflictos es claro que éstos son inherentes a la cotidianidad de la escuela; lo que puede marcar la diferencia es la manera como los actores sociales la enfrentan, que puede ser desde una óptica constructiva, donde los conflictos se ventilan y se buscan estrategias basadas en acuerdos o destructiva, en la que la palabra no tiene espacio y cada uno de los actores conservan sus posiciones antagónicas sin que haya lugar al diálogo y a los acuerdos.

Cuando los problemas se enfrentan de manera constructiva, éstos se convierten en espacios de crecimiento para todos, lo contrario puede generar conductas violentas, de difícil solución. Observamos que la experiencia de algunos maestros y su deseo de establecer vínculos adecuados con sus estudiantes, genera actitudes favorables en el ambiente escolar, en otros casos, el maestro desmotivado con la enseñanza y con escaso compromiso se enfrenta a los conflictos de manera negativa.

Así, el manejo inadecuado de los conflictos en la escuela, involucra directamente al maestro, por ser éste, quien tiene la autoridad para reconocerlos y gestionar su solución; la manera como se resuelvan, denotará la actitud de éste, para enfrentar las situaciones y la calidad de los intercambios que establece con sus estudiantes. El reconocimiento del conflicto por otra parte, facilitaría su solución. 


\section{El apoyo institucional}

El maestro se declara sin herramientas y sin real apoyo institucional para enfrentar la violencia. Considera que su formación en este aspecto es precaria, y que sus responsabilidades deben privilegiar el trabajo académico. Por otra parte, la institución no tiene mayor influencia sobre la familia. Pocos proyectos involucran a los padres. Sin embargo, al preguntar a los maestros sobre las estrategias que utiliza para hacerle frente a la violencia, todos afirman desde su mirada de sí mismos que las medidas que pone en juego son eficaces y efectivas para controlarla

Se percibe entonces, cansancio de los maestros y acomodación a la violencia. Algunos señalan una visión más positiva de la situación considerando que la integración de la familia al ámbito escolar facilitaría la solución de los problemas de violencia.

Se destaca también el hecho de que la violencia se haya instalado en todos los ámbitos, y se viva intolerancia e inseguridad en el entorno. La desigualdad presente en la sociedad es percibida como un factor de inequidad que produce violencia, y tienden ellos mismos a verse en un rol pasivo sin herramientas para enfrentarla, involucrados en una tarea de gran dificultad.

Con ello, el profesor adopta una postura de espectador, incapaz de revertir la violencia que se genera en el aula; sin embargo, otros de mirada más positiva conciben la posibilidad de hacerle frente a la problemática con una postura más dinámica.

\section{La percepción que el maestro tiene del estudiante}

Respecto a la percepción que los maestros han elaborado de sus estudiantes, cuando enuncian sus rasgos más relevantes, resalta el hecho que la mayoría los considera como agresivos e indisciplinados. Se pone de relieve que el cambio en intensidad y frecuencia de las conductas violentas cambia la relación entre ellos. Se percibe temor frente a la pérdida de autoridad del maestro, pero también se percibe que la institución educativa pierde liderazgo y fuerza como agente socializador, frente a otros agentes sociales como la familia, el barrio y los medios de comunicación.

La postura del profesor, de negar la violencia, excluye la posibilidad de que el ambiente institucional sea el causante. El reconocimiento de la existencia de conflicto facilita que las tensiones se discutan y se den los espacios para darle el lugar a la palabra. 


\section{Espacios y tipos de agresividad}

El estudio permite afirmar que los espacios de mayor agresividad en la institución son: el aula, el patio de recreo y la salida del colegio. Los tipos de violencia que más sobresalen en la mirada que el profesor hace de ella son: el acoso escolar o bullying, evidenciado en burlas, golpes, amenazas, robos, el castigo físico o psicológico, que consiste en malos tratos, palabras soeces, groserías, humillaciones y en algunos casos la exclusión, práctica manifiesta en discriminación por creencias religiosas, factores económicos, de género, y de etnia, que por lo general implican al maestro de manera frecuente. La exclusión se ha convertido en un problema delicado, por el desplazamiento que ha sufrido la población colombiana como resultado del conflicto armado, y que ha posibilitado la llegada de niños con culturas diferentes a la cultura urbana de Bogotá y a la cultura del maestro, y se han convertido en presa fácil de la discriminación y de la exclusión.

\section{Clima escolar}

El estudio del fenómeno de la violencia en la escuela, nos puso de presente el ambiente institucional que de manera cotidiana viven alumnos, maestros, directivos y demás personal en los colegios del Distrito Capital.

Tal ambiente, referido a espacios, tiempos e interacciones, entre los diferentes actores educativos, culturas, formas de administrar, ha sido denominado por los investigadores como clima escolar.

El clima escolar ha sido conceptuado como la calidad general del centro que se manifiesta en las interacciones sociales percibidas y expresados por quienes lo integran. Hace alusión a la percepción colectiva sobre las relaciones interpersonales que se generan en el espacio educativo y que influye, de manera decidida, en el comportamiento de la comunidad educativa.

Ha sido también definido como el 'ambiente' total de un centro educativo en el que intervienen todos los factores que lo integran: físicos, estructurales, personales, administrativos y culturales, que constituidos, dan una configuración especial, manifiesta en un particular 'estilo o tono' y que se evidencia en una forma especial de relacionarse y en los productos educativos.

Catherine Blaya afirma que: 
[...] Aunque es difícil definir qué es clima escolar, y desde la psicología se impone un matiz interpersonal importante... estamos de acuerdo con aquellos autores... que afirman que el clima es la calidad general del centro que emerge de las relaciones interpersonales percibidas y experimentadas por los miembros de la comunidad educativa. El clima se basa en la percepción colectiva sobre las relaciones interpersonales que se establecen en el centro y es un factor influyente en los comportamientos de los miembros de la comunidad educativa. (Blaya et. al., 2006: 3)

Para tener un ambiente escolar seguro es necesario que se demuestre respeto, comunicación y responsabilidad mutua hacia los que nos rodean día a día. Un ambiente escolar positivo brinda a todos los actores educativos, herramientas necesarias para manejar los conflictos de manera no violenta.

Se argumenta con frecuencia que un clima escolar estimulante, cálido y seguro, es la base para impulsar el mejoramiento académico, pero también para prevenir la violencia y combatir las adicciones. (Ortega Salazar et. al., 2005: 147)

La vida plena en una institución implica adoptar una actitud de sinceridad, de respeto mutuo, de sentido de la justicia, de respeto a la legalidad, de tolerancia, de simpatía y de rechazo a toda discriminación por razones de grupo étnico o sexo. (Monclus \& Saban, 2006: 33)

En algunas instituciones donde la violencia ha disminuido por efecto del trabajo en equipo de docentes y directivos, se observa respeto hacia todos los actores educativos, hay planeación institucional y liderazgo de sus directivos y docentes y la comunicación y el diálogo son utilizados como herramienta para la convivencia. El clima escolar en estas instituciones, se manifiesta de una especial manera como diría Blaya: con un particular 'estilo' y 'tono', de manera que se genera sensación de tranquilidad y seguridad en las interacciones que se dan a todo nivel.

Eric Debarbieux, propone para la valoración del clima escolar tener presente algunos indicadores relacionados con el entorno como: (Blaya et. al., 2006: 7)

- Percepción, sobre clima general;

- Percepción de comportamientos y actos de violencia;

- Percepción de la calidad del entorno cercano al centro escolar;

- Percepción de las relaciones entre compañeros, con el profesorado y con otros adultos del centro; 
- Percepción de la efectividad del aprendizaje;

- Percepción general de tensión entre docentes y alumnado.

Intentaremos hacer algunas aproximaciones al respecto. Sin embargo, el resultado de nuestro estudio, nos ha mostrado que las percepciones de los maestros respecto al clima escolar, están referidas de manera especial a las relaciones con los directivos, sean coordinadores o rectores y que éstas, constituyen un verdadero problema al interior de las instituciones comparadas con otras percepciones relacionadas con sus colegas y con sus estudiantes, espacios e infraestructura, entre otros.

Afirmamos, que las miradas y perspectivas son posibilidades que se constituyen en una forma de identificar a un grupo a través de sus representaciones sociales, para comprender los significados sociales que le dan sentido.

Una mirada sobre las dimensiones del clima escolar la constituyen los estudios de Eric Debarbieux y Catherine Blaya, sobre el fenómeno de la multivictimización.

Afirman que son los escolares víctimas de sus compañeros, los que tienen la percepción más negativa sobre todas las dimensiones del clima; han denominado multivictimizacion, a un factor de degradación del clima y de la calidad de las relaciones interpersonales, en cuanto que no sólo afecta, psicológicamente, de forma seria a los individuos, sino que éstos, al sentirse mucho más vulnerables, en todos los aspectos, incluyen un factor social de riesgo al clima de relaciones en la escuela.

\section{Percepciones sobre el clima general de la institución}

El tiempo limitado que el maestro pasa en la institución le impide verificar la verdad de sus percepciones. Las percepciones son inmediatamente imágenes y sentimientos. Lo imaginario se apodera del alumno y le impide conocer al enseñante tal como éste es. Lo imaginario se adueña también del maestro que es el primer solicitante, puesto que tiene la iniciativa de los mensajes y de la palabra. (Abraham, 2000)

Al examinar cómo es percibido el clima escolar por los maestros y su nivel de participación en él, encontramos que a pesar de que los maestros privilegian 
la relación afectiva y cariñosa con sus alumnos, dada la representación ideal que tienen del vínculo, entre los dos, la sobrecarga de trabajo que los obliga a realizar múltiples actividades en el corto espacio de la jornada laboral, representa un motivo de tensión que se expresa en respuestas cortantes, desatención de solicitudes de parte del alumno, indiferencia ante quejas, disputas, o ante solicitudes de diálogo.

Estas contradicciones expresan una oposición entre el ser y el deber ser, de manera que aunque consideren que el vínculo ideal deba expresarse mediante la comunicación y el respeto, se sienten impotentes para resolver muchos de los eventos que acontecen en el espacio escolar a través del diálogo.

No es raro, en estos casos, manifestar que la violencia es exterior al ámbito escolar, hecho que justificaría la exclusión como parte de las acciones representacionales que, al decir de Moscovici: "Se refiere a un conjunto de conductas regulares realizadas con la aprobación del grupo y que corresponden con las creencias compartidas, pero no verbalizadas acerca de la violencia en la escuela”. (Moscovici, 1961)

Respecto a la violencia que se genera en la escuela, opinan los maestros que el clima escolar no influye en el origen de la misma y, si lo aceptan, lo atribuyen a la convivencia con niños que viene de hogares violentos.

El clima social y psicológico del aula y de la institución tiende a negar una serie de valores implícitos para la construcción de una sociedad participativa y democrática, y en las aulas y pasillos se dan cita una multiplicidad de valores tanto de maestros como de alumnos. Si bien es cierto que los docentes fomentan —desde el deber ser-, valores como la tolerancia, la participación, el respeto a la persona y a la diversidad de opiniones; los alumnos también promueven otros que forman parte de un código alterno.

Maestros y alumnos leen e interpretan los significados y las prácticas educativas por medio de principios selectivos, que mediatizan el peso de situaciones e ideologías preexistentes. Los alumnos gozan de una relativa autonomía, articulada con factores subjetivos, necesidades y deseos, principios e ideales propios de la estructura de la personalidad de cada individuo, así como a un conjunto de intereses específicos: culturales, de clase, género o grupo étnico, desarrollados en el ámbito extraescolar que le dan significado a la interacción maestro-alumno y a la relación de éstos consigo mismos, con el conocimiento y con la práctica social 
y que, a la vez, se constituyen en eslabones cruciales entre "los determinantes estructurales y culturales de la educación”. (Willis citado por Gómez Nashiki)

Sin embargo, es necesario señalar que en la institución educativa son muchos los alumnos que no se sienten reconocidos en el aula, porque los contenidos curriculares que se trabajan en la escuela excluyen los grupos sociales, culturales, lingüísticos y étnicos a los cuales éstos pertenecen.

El desconocimiento de los contextos culturales de los alumnos y los prejuicios que se tiene de los grupos desfavorecidos, imprime un cierto tono y estilo a los ambientes educativos, además de generar expectativas que no siempre se cumplen respecto a sus posibilidades académicas. Por ello, no es raro escuchar a unos pocos maestros, afirmar, que la formación académica no es tan importante, porque las posibilidades futuras, de estos chicos, son nulas frente al ingreso a estudios superiores o formaciones que puedan asegurarles un mejor futuro.

Paul Willis demuestra en su libro Aprendiendo a trabajar, cómo es esta imposición ideológica la que transforma jóvenes estudiantes en obreros para ser incorporados dentro del sistema capitalista; Willis muestra esto en forma explícita a través de los procesos académicos y disciplinarios, consolidados en la escuela, en donde el objetivo de incorporar a los estudiantes a la vida laboral es evidente, así como la resistencia que presentan los jóvenes y luego los obreros. (Willis, 2009)

Una manera de disminuir el peso de las miradas excluyentes y las representaciones donde el alumnado no tiene mayores posibilidades sería: "Promover una enseñanza reflexiva, crítica y democrática en la cual docentes y alumnos sean reflexivos, críticos y democráticos". (Torres: 81 )

Sin embargo, es llamativo que la mayoría de maestros afirme privilegiar tanto la formación académica como la formación en valores, pero cuando se les pregunta qué tipos de valores promueven, parecen no tener claridad, y algunos con honestidad afirman darle todo el peso al currículo, dado que serán evaluados por los resultados académicos y el cumplimiento de los programas.

\section{Percepción de los espacios físicos}

Respecto a los espacios físicos, algunos maestros le otorgan cierta importancia como génesis de conductas inapropiadas. Una maestra se expresa así: 
[...] Nosotros teníamos a los estudiantes en total hacinamiento por falta de espacios. Debíamos mantenerlos todo el tiempo en el salón. Yo salí de una reunión de salud y por no llegar tarde a clase preferí irme directamente al salón, a pesar de que no había podido entrar al baño en toda la tarde. Consideré importante dar la clase y salirme cinco minutos antes porque era la última hora. Entonces les dejé una ecuación para que la resolvieran y la rectora llega mientras estaba en el baño. Se salió de los chiros...eso fue grito y pataleo y me mandó a buscar por todo lado y claro no me encontraban porque yo estaba en el baño. (Maestra 023, 15 de abril de 2009)

En esta situación, dos problemáticas se dan al mismo tiempo: la preocupación de la rectora porque los alumnos están solos en un salón inadecuado y la atención a una necesidad básica por parte de la maestra. En ese sentido, los espacios adecuados y los tiempos como criterios de calidad y de auto cuidado son fundamentales en la percepción del clima escolar, pero también el respeto y la tolerancia influyen de manera definitiva.

El trabajo docente se realiza en unas condiciones poco favorables. Aunque en algunos colegios visitados encontramos amplias instalaciones, la mayoría no cuenta con los servicios de cafetería, baños para maestros, lugares de atención a los estudiantes o a padres. El compromiso de ellos es el que posibilita asumir las tareas y superar las dificultades en beneficio de los resultados.

Los maestros consideran que los recursos institucionales son limitados y los requerimientos que les hace la institución son excesivos. El auto cuidado está desatendido por el mismo maestro y esto genera, en muchos casos, frustración.

El descuido de los bienes materiales de la escuela y el desorden, generan motivos de disgusto; sin embargo, algunos maestros parecen vivir ajenos al espacio escolar, o estar acostumbrados al estado de deterioro del colegio. En general, se expresan diciendo que si rayan las mesas de trabajo sólo son formas de expresión y hay que tolerarlas. Así, también otras formas de expresión terminan por ser no vistas $\mathrm{y}$, a la postre, generan ambientes escolares tensos y son motivo de violencia.

Pero con relación a las nuevas instalaciones en la mayoría de colegios los maestros expresan sentirse mejor y consideran que se ha mejorado el clima escolar. Una maestra se expresa en este sentido:

[...] Me he puesto a analizar y me he dado cuenta que con las nuevas instalaciones, otra planta física, ha mejorado también la convivencia, cuando 
nos tocó salir de acá a un centro comunitario, ustedes lo conocen, bueno en el centro comunitario tenían unos salones adaptados; eran unas bodegas adaptadas a salones, una acústica tenaz y otros en unas casitas que nos había instalado la Secretaria de Educación y era muy difícil controlar a los alumnos, se salían, y era un pasadero de todos las personas que van a hacer actividad allá; llegaban indigentes, personas de la tercera edad, los chicos se confundían con tanta gente, en las últimas horas de clase, habían menos de la mitad de los cursos y no podíamos los maestros ir por todo ese centro a buscarlos, fue bien difícil esa época. (Maestra 005, 13 de febrero de 2009)

\section{Percepción de la relación con los colegas}

Durante varias horas al día, los maestros comparten entre sí y con los alumnos espacios y situaciones en un clima que puede ser grato, pero que también puede ser de tensión y de crisis. Compartir con otros sujetos significa tener capacidad para ejercitar la cooperación, para reconocer problemas y herramientas para resolverlos sin que otros se sientan vulnerados.

Silvina Chemen afirma:

[...] La tolerancia a la frustración es una condición necesaria para enfrentar conflictos...Vivimos en un mundo de inmediatez: escuchamos: ahora o nunca, esto lo necesito para ayer... se debe entregar la evaluación escrita, cuando toca el timbre. Así vivimos los adultos y éste es el mundo en el que crecen los más pequeños. (Chemen: 157)

En este entorno, resulta utópico mantener un clima escolar armónico, menos aún plantear mecanismos de resolución de conflictos, que revisen las formas más adecuadas de comunicación. En tal sentido afirma una maestra: "Si alguien me cae mal, pues comparto el saludo y nada más, claro hay días que algunos pasan por el lado y no lo conocen a una, eso es lo más normal. Por eso termina una buscando sus iguales y sus iguales se entienden. Los grupitos son los que favorecen el clima escolar. (Maestra 033, 29 de mayo de 2009)

Algunos maestros se refieren a la dificultad de compartir puntos de vista de tipo político que pueden constituirse en ingredientes para crear tensiones al interior del colegio y generar un clima escolar tenso, pero prevalece el respeto por las decisiones y opciones de cada uno.

[...] de pronto hay maestros que no están conformes en el espacio que compartimos, pero aquí la mayoría, nos sentimos bien y tomamos partido 
en la actividad política: asistimos a las marchas, nos gusta la parte sindical, y es el sentir de la mayoría, pero hay una compañera, ella nunca lo dice en voz alta, no sé si es porque piensa que la vamos a cuestionar, que no comparte nuestras opiniones, pero tampoco asiste a ningún acto y sin embargo, nosotros le respetamos su manera de ser. (Maestra 011, 13 de febrero de 2009)

Los profesores también señalan como un problema que está presente en el clima escolar, la imposibilidad de compartir con sus colegas. Una profesora señala:

[...] Este es por ejemplo mi horario: (la profesora despliega sobre la mesa un horario donde se muestran sus bloques de clase y las horas asignadas a otras actividades que le dejan muy poco tiempo para atender, por ejemplo a los padres de familia), hoy miércoles tenía: reunión de área, reunión de comisión de promoción y evaluación, y clase con 6-1, 6-3, y 8-2, por eso es que nosotros los maestros cuando nos saludamos, es porque nos encontramos en el patio y solamente nos decimos que hubo, que más, cómo estás, y ya. (Maestra 023, 15 de abril de 2009)

Las reformas educativas han promovido una concepción tecnocrática del trabajo docente y un currículo sobrecargado de contenidos.

Los conflictos entre maestros, aunque no sean un problema fundamental en el grado de aprobación o rechazo del clima escolar, generan tensión sobre todo aquellos que datan de años atrás. Cuando deben tomar decisiones colectivas, esos conflictos se ven reflejados en los acuerdos y surgen las divisiones más por pertenencia al grupo que por una lógica que oriente las decisiones. Sin embargo, en decisiones a nivel externo de la institución a pesar de los conflictos, predomina el sentimiento de pertenencia.

Los maestros que tiene una postura activa frente a los problemas de la institución son críticos con la formación deficitaria que tiene algunos de sus colegas, pero sobre todo con la falta de compromiso y responsabilidad. Los que tiene una actitud pasiva se consideran sin competencia para asumir los problemas que genera la violencia y dependen de las instrucciones que dé, la autoridad.

Los estudiantes en general, según los mismos maestros, perciben el vínculo negativo entre maestros y también toman partido, reproduciendo el modelo en sus relaciones con sus iguales. Así podemos entender que la institución educativa moviliza cargas y representaciones de afecto o de odio que aseguran la pertenencia del sujeto a un conjunto social. 


\title{
Percepción de la relación con los directivos
}

Una de las problemáticas más resaltadas en los grupos focales y en las entrevistas fue la relacionada con la mirada que tienen de los rectores y el personal de docentes directivos. Resaltan su falta de liderazgo, su dificultad para crear un ambiente de respeto y su errático manejo del poder. Pero además señalan su falta de planeación y el manejo inadecuado de las situaciones de violencia que se dan en la institución escolar.

La falta de coordinación y de planeación de las actividades en los colegios, genera indisciplina y desorden, y hace que se pierda el efecto educativo para los alumnos. El ambiente escolar se deteriora y se genera malestar entre la comunidad educativa.

Observamos en una institución a dos coordinadoras académicas que no tenían funciones claras respecto a su quehacer, ninguna de las dos tomaba decisiones y en las reuniones permanecían en silencio. Al no asumir sus funciones, los maestros se veían obligados a actuar y a resolver los vacíos. Sobre esta situación se refiere una maestra de la siguiente manera:

\begin{abstract}
[...] Se espera que las coordinaciones hagan una programación mensual, bimensual o semestral donde no se crucen las actividades. Donde todas sean igualmente importantes. La falta de coordinación y liderazgo en la persona que orienta las actividades académicas en una institución hace que se pierda la oportunidad de que toda la comunidad educativa pueda vivenciar estas actividades que son formativas. Esto genera un clima escolar de mucha tensión, desorden e indisciplina. Cada nivel por su lado sin que haya integración de los esfuerzos ni formativos ni económicos. (Maestro 035, 29 de mayo de 2009)
\end{abstract}

Se argumenta la falta de directrices por parte de algunos rectores. ¿Aquí quién manda?, ¿quién decide? se pregunta una maestra. La imagen del rector es la de un gerente empresarial, su preocupación está centrada en lo económico, pero los aspectos académicos y de convivencia nadie los maneja, la institución, según ellos, anda a la deriva.

Otro problema que se señala como causa de un clima escolar poco facilitador de trabajo armónico es el carácter a veces autoritario de los rectores, la negación de la autoridad del docente, la ausencia de comunicación y las trabas para el ejercicio de los procesos académicos. En este punto se podría interpretar la presencia de cierto grado de competencia que impide llegar a acuerdos pero también y de 
manera especial, aparece la dificultad que se tiene para manejar los conflictos a partir de la negociación.

Estamos de acuerdo con Chiappe cuando afirma que:

[...] Va a ser necesario gestar un nuevo tipo de interacción que tenga en su núcleo la confrontación y el debate, que permita comenzar una elaboración colectiva de normas, en la cual la negociación entre establecimientos, autoridades y docentes encuentre en el acuerdo, una nueva forma de resolver los conflictos, así el proceso mismo se convierta en escuela práctica-teórica de procesos para construir normas y acordar valores. (Chiappe, 1999: 116)

El mundo de los conflictos supone vivir en el mundo de la negociación. De manera permanente estamos negociando acuerdos sean materiales o simbólicos, gracias al desarrollo de las competencias comunicativas de las que disponemos, sobre todo la habilidad de escuchar al otro y comprender su punto de vista requiere de un alto sentido de la tolerancia, entendida como esa capacidad que nos habilita para comprender los diferentes argumentos, ideas, tradiciones, para reconocer al otro tal cual es. Darle prioridad a este aspecto es fundamental para la construcción de la convivencia, la adquisición de habilidades para la resolución de conflictos, y el respeto por sí mismo y por los demás. (Chemen: 150)

En los colegios grandes, el clima escolar se vio afectado por efecto de la fusión de los colegios y las rivalidades entre sus directivos, al tener que dejar a un solo rector. Las consecuencias de esta situación aún perduran y los docentes tienen la percepción de que los alumnos son un número más en colegios donde se cuenta con más de tres mil alumnos. Al contrario, en los colegios pequeños se posibilita la comunicación, todos se conocen y el clima escolar resulta ser armónico; es más fácil transmitir entusiasmo por las tareas que se proponen así como la capacidad de éxito.

Es posible que en estos colegios, la afirmación frecuente de que el maestro no tiene herramientas para manejar la violencia en un clima escolar viciado, y que no está preparado para trabajar en ese tipo de colegios, además de escasa claridad sobre situaciones que pueden ser manejadas y transformadas desde el interior de la institución, terminen por restar importancia a las acciones de promoción de la convivencia.

Finalmente para crear un clima escolar seguro, es necesario que se demuestre respeto, comunicación y responsabilidad mutua hacia los que nos rodean día a 
día. Un ambiente escolar positivo les brinda a los jóvenes herramientas necesarias para manejar los conflictos de formas no violentas.

Según Carpinelo, S, las siguientes son algunas maneras de facilitar la creación de este tipo de ambiente: Programas de consejería para el manejo del coraje. Programas de mediación y resolución de conflictos. Un sistema confidencial que les permita a los jóvenes alertar al maestro sobre sus preocupaciones con relación a sus compañeros. Es importante recalcar la diferencia entre ser un "soplón" y proteger su seguridad. Intervenciones de alcohol y drogas para los jóvenes y sus familias. Enlaces con las agencias que les sirven a jóvenes y con las agencias policíacas en la comunidad. (Carpinelo, 2005)

No hay duda que existe variedad de puntos de vista en las percepciones que los profesores expresan, respecto al clima escolar; sin embargo, a la hora de intervenir en el problema debe tenerse en cuenta que:

[...] El educador debe comprometerse a crear en el entorno escolar un ambiente de armonía, comprensión, valoración, afecto y respeto, para fortalecer la identidad regional y promover lo mejor de su cultura, de tal manera que el estudiante sienta que este espacio es verdaderamente un buen hogar y que reciba en él lo que le es negado en el seno familiar. Este cambio se logrará cuando el educador propicie la recreación con fines formativos, cuando innove pedagógicamente en el proceso de adquisición del conocimiento, promueva y orienta eventos culturales, de sana competencia. (Cruz, 1997)

Un clima escolar positivo puede facilitarle a los jóvenes herramientas necesarias para manejar los conflictos de manera no violenta. 



\title{
Disciplinamiento asociado a situaciones de violencia escolar
}

\begin{abstract}
A la fecha se cuenta con investigaciones que han analizado en extenso el proceso de transformación de la educación familiar a la educación pública, y los cambios en los roles que padres y maestros tuvieron que asumir en el ejercicio de su función educadora, así como los conflictos generados entre ambos por las transformaciones de la modernidad educativa apoyadas en el desplazamiento y la delegación de funciones sociales que en los siglos precedentes, habían sido competencia únicamente del padre de familia.
\end{abstract}

Dichas tensiones entre familia y escuela no han cesado en lo contemporáneo, y como consecuencia de este conflicto de roles se puede observar la distancia social entre padres y maestros, el deterioro de la confianza que las familias depositaron en la educación y la autoridad de padres, madres y maestros minada por el mutuo desconocimiento entre unos y otros. (García Sánchez, 2007: 326)

Esta situación tiene sus implicaciones directas en las relaciones entre padres y maestros, interfiriendo con el cumplimiento de las metas culturales encaminadas a lograr la tarea socializadora de los niños y las niñas.

Consideramos que el proyecto moderno profundizó el deterioro de la relación familia y escuela, al punto que a partir de las últimas décadas del siglo $\mathrm{XX}$, innumerables familias en el mundo de occidente empezaron a optar por no enviar sus hijos a las escuelas, retornando a la educación en casa y creando un movimiento mundial, denominado 'educación libre', como la expresión del desencanto de las familias del proyecto moderno, basado en la educación pública homogenizante y masificadora que profundizó las distancias entre padres y maestros, que apartó a los padres de la función educadora eclipsando su papel y confundiendo quehaceres de padres y maestros y otorgando a la escuela funciones sociales que fueron más allá de sus posibilidades, desbordándola y colocando al maestro en un estado de agotamiento y sin salida profesional.

Para la mayoría de la población que continúa siendo usuaria de la educación pública o privada, el deterioro de las relaciones entre familia y educación se 
traduce en menor responsabilidad parental y en menor responsabilidad pedagógica, discontinuidad en la formación de capital cultural familiar y capital cultural escolar, desconocimiento mutuo tanto de los proyectos familiares como de los proyectos pedagógicos y discrepancia / antagonismo entre los valores y normas de las familias con los de la escuela. (García Sánchez, 2008: 108-124)

Según Tedesco, son precisamente estos elementos los que configuran el proceso de socialización imperfecta, debido a la imposibilidad de construcción de un proyecto común y a la pérdida de capacidad, tanto de la familia como de la escuela, para transmitir valores y pautas culturales de cohesión social y carencia de unidad y mensaje socializador.

\section{La nueva responsabilidad pedagógica}

Así como hoy se dispone de un nuevo concepto sobre la responsabilidad parental, que reemplaza el de autoridad parental, asignando otras dinámicas a las relaciones familiares, consideramos que en este mismo sentido se transformará la autoridad pedagógica. Mientras que la autoridad parental estaba relacionada con el ejercicio del poder compartido, la igualdad de derechos del padre y la madre en el cuidado y educación de los hijos, la responsabilidad parental significa la obligación social, igualmente compartida y solidaria entre los padres para responder por la satisfacción de los derechos de los hijos e hijas, dejando claro que para el ejercicio de dicha responsabilidad no podrá usarse la violencia en cualquiera de sus formas.

Con esta última afirmación del Código de Infancia y Adolescencia, se pretende poner límite al uso de la fuerza y se borra todo concepto de autoridad como poder-dominación, instaurando allí una nueva manera de ser padre y madre que implica una relación social de solidaridad, de cooperación, de confianza y de respeto de los derechos humanos de niños, niñas y adolescentes. Así, de la 'autoridad' para educar a los hijos e hijas, se pasó a la 'responsabilidad' social de formarlos, recogiendo el sentido de la legislación del siglo XXI para la población infanto-juvenil en América Latina y en diferentes países de occidente, en la que se "reclama la sustitución del poder de corrección por el derecho de orientación o guía de los las padres madres, con la consecuente prohibición de brindar a los hijos/hijas cualquier tipo de trato humillante, vejatorio y violento". (Herrera, 2010)

En consecuencia, la nueva responsabilidad pedagógica implica la obligación social de los maestros de formar a los estudiantes en el marco del respeto de 
los derechos y deberes de niños, niñas y adolescentes; en este enfoque de la responsabilidad pedagógica, la población infanto juvenil tiene el derecho de orientación y guía de sus maestros mediante el establecimiento de relaciones sociales construidas sobre el trato digno y respetuoso.

Así como se modifica el estatus de autoridad de los padres y madres en el mundo contemporáneo, también se modifican las relaciones de los adultos, cuidadores y maestros con la población infantil. Sin embargo, de acuerdo con Bourdieu, no hay posibilidad de acción pedagógica sin autoridad pedagógica autónoma y reconocida socialmente para ejercerla. (Bourdieu, 1977: 52)

Este reconocimiento de la autoridad pedagógica también se ha transformado en lo contemporáneo, debiendo ser reconocida tanto por padres y madres como por estudiantes y la sociedad en general, pero el trasfondo histórico que ha permeado las relaciones entre familia y educación ha minado dicha autoridad y en consecuencia sus acciones se han descontextualizado quedando, la mayoría de las veces sin sentido.

\section{Prácticas de disciplinamiento escolar}

La delegación de funciones educativas de los padres a los maestros, incluyó el ejercicio del disciplinamiento escolar a través del uso del castigo, de la misma manera como lo realizaban los padres en el espacio doméstico, conservando en ambos la connotación formativa. Estudios como el de Philippe Aries sobre la historia del castigo escolar en Francia, en los siglos xV a XVII, han dejado claro, de una parte, el carácter humillante del castigo y de otra, la prolongación de la edad escolar susceptible de recibir la pena del látigo. Con respecto a lo primero aclara que, "todos los niños y jóvenes, cualesquiera fuese su extracción, estaban sujetos al régimen común y recibían latigazos", (Aries, 1987: 64)

Y con respecto a lo segundo, señaló que la pena del látigo "al principio estaba reservada a los más pequeños y luego se extiende a partir del siglo XVI a toda la población escolar que ronda frecuentemente, hasta superar los veinte años" (Aries: 65)

Lawrence Stone, aclaró, cómo el azote fue la práctica más usada en Inglaterra durante el siglo XVIII, hasta el punto que cada pueblo tenía su poste para azotar, el cual se usaba constantemente para preservar el orden social tanto en la casa como en la escuela. (Stone, 1989: 100) 
Comenzando el período republicano, en Colombia, las nuevas leyes imprimieron límites al abuso de castigos físicos que los padres y maestros infringían a niños y jóvenes; sin embargo, su uso continuó siendo la principal medida de control de niños y jóvenes durante todo el siglo XIX. El sentido de la escuela del siglo XX estuvo cifrado en homogenizar, disciplinar y civilizar, pero imponiendo límites a los maestros en el uso del castigo físico, específicamente a partir de las última década del mismo. (Martínez Boom, 2004: 340)

Las disposiciones del Código de Infancia y Adolescencia de 2006, llevaron al límite el uso del castigo físico por parte de los maestros como medida de control, y en este sentido ha sido sensible su disminución, aunque las estadísticas del INML 2008 y los archivos de las Comisarías de Familia de Bogotá, reportan la vigencia del uso del maltrato verbal y psicológico y, en algunos casos, abuso sexual por parte de los maestros.

En encuentros realizados con padres y madres de familia en Bogotá en 2009, se reconoció que si bien los maestros dejaron de hacer uso del castigo físico para corregir y castigar a los estudiantes, adoptaron la posición de denunciar a niños, niñas y jóvenes o ante las Comisarías de Familia o el Instituto Colombiano de Bienestar Familiar o ante los propios padres y/o madres de familia, reclamando el control y el castigo que los maestros no pueden ejercer, además, asumieron, en muchos casos, una posición de indiferencia.

Una vez cursados internamente los procedimientos disciplinarios al interior de las instituciones educativas, a partir del año 2006 se aumentaron las denuncias de los directivos docentes, maestros y orientadores sobre los comportamientos de la población infanto-juvenil en conflicto con las normas contempladas en los reglamentos educativos. Pero lo que encontramos es que a mayores denuncias menor trabajo pedagógico, educativo o reeducativo en las instituciones educativas.

Si bien es cierto que esta nueva actitud del maestro denota la aceptación de los límites al uso del castigo en cualquiera de sus formas, también evidencia las carencias pedagógicas en la formación docente cuando se trata de implementar procesos adecuados para que los estudiantes comprendan la naturaleza de sus actos, o cuando se hace necesario aplicar sanciones o adelantar procesos educativos que involucren la participación de padres y madres de familia.

Al despojar el castigo físico de su función normativa, dicha práctica es interpretada como una expresión inaceptable de maltrato escolar entre maestros y 
estudiantes, como lo expresa una madre de familia con respecto a una situación entre su hija adolescente y el maestro. Dice el profesor a la estudiante:

"Me hace el favor y delante de todos sus compañeros me pide disculpas" entonces la estudiante le dice "yo porqué le voy a pedir disculpas profesor si usted fue el primero que me tiró a mí el puesto, usted fue el primero que me trató mal a mí, cuando usted me pida disculpas, yo se las pido a usted, de lo contrario yo no tengo porqué pedirle disculpas a usted”. (Sesión No. 4, marzo 28 de 2009)

Es necesario aclarar que el maltrato entre maestros y estudiantes ha disminuido sensiblemente y que la frecuencia de datos empíricos es mucho menor al maltrato reportado por padres y madres de familia; por ejemplo, el INML reportó en 2008 , sólo 51 casos de maltrato de profesores a estudiantes, frente a 6.701 casos de maltrato infantil de padres y madres a niños, niñas y adolescentes. (Carreño, 2008: 113)

Aun así queremos registrar algunos de los casos reportados sobre maltrato escolar de profesores a estudiantes, tanto en las Comisarías de Familia consultadas, como por los padres y madres de familia que participaron en la investigación, por considerarlos relevantes:

Burla de maestra a estudiante: Dice una madre de familia:

[...] El miércoles o el jueves, me tocó entrar a hablar con la profesora de danza, pues mi niña me dijo que la profesora la boletió en el sentido de que ella no tenía tenis (Ilora), los tenis estaban rotos y cuando llueve se pone talegos, y se le vieron los deditos afuera, la profesora empezó a burlarse de ella junto con otros niños del salón; mi niña salió a llorar; yo le dije que no llorara, que yo entraba y hablaba; la profesora me dijo que la perdonara, que era una chanza; yo le dije, no, eso no es chanza, póngase en mi lugar, a mi hija no me la boletié así, le voy a demostrar que aunque yo soy pobre, mi hija le va a traer los tenis mañana, y así lo hice. (Sesión No. 6, 18 de abril de 2009)

Algunos casos de maltrato verbal de maestros a estudiantes fueron reportados por padres y madres, donde expresan: algunos maestros del colegio tratan con irrespeto a los estudiantes, y se refieren a ellos con palabras ofensivas: "No los saben tratar, o sea como que los estrujan y no le saben decir bien las cosas, les dicen que son unos maricas". (Madre 018, 20 de marzo de 2009) 
"Me parece horrible en el colegio, porque los profesores tratan muy mal los muchachos, les dicen "quiubo maricas", "estúpidos", entonces, ¿qué muchacho va a respetar a un profesor de esos?”. (Madre 026, 28 de marzo 2009).

Una madre de familia comenta que hay un maestro que les dice a los estudiantes: "es que esta manada no la maneja nadie" animales, bestias salvajes, lo peor son los alumnos. (Madre 026, 28 de marzo 2009).

[...] Aquí en el colegio hay una cosa que a mí me disgusta y es cuando los maestros se refieren a los alumnos con expresiones como este gamín; yo lo he escuchado, lo he escuchado a la coordinadora y a un profesor. (Padre 001, 6 de febrero de 2009)

Una madre de familia dice:

[...] En esta sesión me hubiera gustado que estuvieran los profesores, ¿por qué? yo vengo a una reunión al colegio los profesores son los más queridos, no hay chocante, todos son los más amables, 'señoras, padres de familia, mamitas', porque así nos dicen, 'mamitas', cuando necesiten algo búsquenos, aquí queremos mucho sus niños'. Si los quisieran no los trataban mal, estos hijuetantas, por eso los muchachos no los respetan. (Madre 026, 18 de abril de 2009)

Negligencia de Rectores: Algunos estudios españoles han señalado que en situaciones de maltrato escolar entre pares, los estudiantes consideran que los directivos y profesores intervienen de manera muy escasa o por indiferencia o por negligencia o porque no se enteran de los hechos y que sólo un tercio de ellos actúa frente a las agresiones. (Defensor Del Pueblo, España, 2000).

Por ejemplo, padres y madres reconocen que no encuentran apoyo en los rectores de las instituciones educativas cuando denuncian situaciones de violencia escolar:

[...] Yo quería denunciar las agresiones que unos alumnos del colegio de la jornada de la tarde le hicieron a mi hijo. Yo fui y le informé personalmente al rector del colegio y el señor me contestó que lo cambiara de colegio, que él no podía hacer nada, para mí es muy difícil cambiar a mi hijo de colegio ya que los gastos de uniforme son muy altos. (Comisaría de Familia, Usaquén, abril de 2007)

Maltrato físico y escarnio público: 
[...] Manifiesta la señora que su hijo tiene un inconveniente con un compañero del colegio y le comentó a un amigo que no es estudiante del colegio, lo cierto es que el señor coordinador del colegio los citó a todos y delante de los muchachos los sacó a empellones de la clase y le tiró la puerta por la cara, a otro le pegó un codazo; ella piensa que esta conducta del señor coordinador es reprochable desde todo punto de vista porque además lo hizo con varios alumnos y piensa seguir haciéndolo porque les dijo que los va a sacar en formación para que pasen al frente y sean objeto de burla de todo el colegio. (Comisaría de Familia, Usaquén, marzo de 2007)

En el estudio mencionado sobre maltrato escolar en España, al ser preguntado el profesorado por su consciencia frente al problema del maltrato escolar, ellos consideran que sí son conscientes de los problemas, aunque los estudiantes respondieron, ante esta misma pregunta que los profesores ignoran la problemática. Los profesores adjudican el problema a la familia y al contexto social. Una tercera parte de ellos, aceptaron que el profesorado insulta o ridiculiza a sus alumnos y a su vez se quejan que los estudiantes tienen comportamientos abusivos con ellos. 



\section{Del disciplinamiento a la exclusión social}

Si bien el uso del castigo en cualquiera de sus formas como medida disciplinar se limitó en Colombia finalizando el siglo XX, perviven prácticas tanto en la familia como en la escuela para ejercer el control, disciplinar, corregir y sancionar que antes de lograr su propósito, la educación y la formación, alimentan el proceso de la exclusión social, pues algunas de estas prácticas influyen en la decisión de niños/niñas/jóvenes sobre la evasión del espacio familiar y luego del espacio escolar, por el ausentismo familiar y el ausentismo escolar y por la deserción o el abandono definitivo de la casa o de la escuela.

En lo que respecta particularmente al espacio escolar, encontramos como práctica contemporánea de control y sanción la desescolarización, la suspensión y la expulsión escolar, sin desconocer que estas son prácticas antiguas en la historia de la educación y que perviven en el sistema educativo moderno.

En las investigaciones realizadas por Rodrigo Parra Sandoval, éste señalaba la persistencia de estas prácticas en Colombia en la década de los años 80 cuando afirmaba que:

\footnotetext{
[...] Existen sanciones contra las transgresiones a las normas institucionales, que van desde el castigo como la expulsión de clase, rebajas en las calificaciones, hasta la suspensión de varios días de clase, con sus respectivas rebajas en las materias que se vean en esos días. Las faltas que más se sancionan son las que hacen referencia a la relación con los profesores, como por ejemplo que un alumno responda en tono fuerte, o diga algo que desagrada al maestro. (Parra Sandoval, 1986)
}

Estas prácticas perviven y no son exclusivas del espacio escolar, pues en algunos casos las sanciones las utilizan los padres y en otras los maestros, a veces, es la población infanto juvenil, quien toma la decisión de evadirse, ausentarse o desertar de la casa o del colegio. Existen profundas interconexiones entre dichas prácticas, entre la familia y la escuela; las circunstancias que intervienen son múltiples, desde las costumbres culturales, la estructura familiar, el nivel educativo y la situación económica de los padres; la construcción de subjetividad de la población infanto-juvenil y la búsqueda de nuevos intereses; la desmotivación y 
la pereza por el estudio, la ausencia de nuevas pedagogías familiares y escolares que aviven el deseo de saber en los hijos/estudiantes; los climas familiares, escolares y barriales inseguros; las relaciones sociales mediadas por la violencia en la familia, en la escuela y en el barrio, entre otras.

El nuevo enfoque en la función social de padres, madres y educadores propicia miedo, incertidumbre y desconcierto en cuanto a los usos tradicionales de la autoridad, de la disciplina y la normatización de los niños, niñas y adolescentes, sobre todo, si se tiene en cuenta que aún sigue vigente en nuestra cultura, asociar autoridad con obediencia, subordinación y castigo.

Así lo expresan dos madres de familia de instituciones oficiales de Bogotá:

[...] El Código de Infancia dañó la juventud, porque les prohibió el castigo a los menores... los jóvenes se descarriaron por la protección al menor y el Código de Infancia. Ya no se puede controlar los hijos porque la ley lo impide. (Encuesta a madre de Familia 012, 20 de febrero de 2009)

"Estas leyes que sacaron tan estúpidas, que cuidado uno le llama la atención al niño porque ahí mismo lo castigan a uno de padre" (Sesión NES, Madre 021, 14 de marzo de 2009).

Para comprender este miedo social de padres y madres de familia de no saber ahora de qué manera relacionarse con niños, niñas y adolescentes, revisaremos las resistencias de padres y maestros frente al ejercicio de la autoridad.

En primera instancia, se pueden constatar las resistencias de padres, madres de familia y educadores ante el espíritu de igualdad y horizontalidad que permean las relaciones contemporáneas con hijos e hijas, invocando la necesidad del restablecimiento de la autoridad de antaño, como un lugar seguro y aprendido desde dónde relacionarse con los niños y niñas en condición de autoridad, respeto y jerarquía.

A esta resistencia a aceptar nuevas formas de relación con los hijos e hijas, y a la añoranza de la autoridad paterna, Domínguez Morano la ha llamado "nostalgia de padre":

[...] Frente al vértigo que puede producir la idea de un futuro abierto a los propios deseos y determinado en la medida de lo posible por la propia responsabilidad, emerge la nostalgia de una palabra firme y decidida que 
oriente el paso y fije las metas a las que dócilmente habría que encaminarse...'nostalgia del padre' (en contraste con la que adquirió popularidad en los años sesenta de "rebelión contra el padre"). (Domínguez Morano, 2010)

Esta nostalgia de padre se hace evidente en los relatos de padres y maestros que participaron en esta investigación, resaltando el deseo de educar a los hijos/ estudiantes con los parámetros como fueron educados en su infancia y asociando autoridad y castigo, elementos que claramente son incompatibles en las tendencias contemporáneas, sin que ello signifique que se hayan erradicado estas prácticas culturales, pero si manifiesta el desconcierto familiar y escolar de cara a cómo relacionarse con los hijos/hijas, estudiantes en la tensión que produce la tradición familiar y escolar versus lo nuevo de la relación social.

En segunda instancia, la saturación de quejas en las instituciones educativas y en las instituciones del sistema de protección del ICBF, respecto a la desobediencia y falta de control de niños, niñas y adolescentes, hace pensar que las viejas estructuras de relación entre adultos e infantes y adolescentes basadas en la obediencia y la sumisión entendida como respeto son imposibles de mantener.

A pesar de las resistencias, de los desconciertos y de la nostalgia de padre, no es posible dejar de avanzar hacia una educación de iguales que posibilite "la conquista de una sociedad sentada sobre las bases de una igualdad fundamental entre todos los seres humanos”. (Domínguez Morano, 2010: 11)

A dos siglos del ideario del proyecto moderno, las estructuras familiares se han replanteado y las condiciones sociales están dadas para formar y educar en la igualdad, en la libertad y en la fraternidad; superar la necesidad primaria de una autoridad que nos contenga, permite el forjamiento de la propia libertad y de la propia autodeterminación, y es allí en donde radica el verdadero sentido de la responsabilidad.

Cuando una madre o un padre reclaman ante los servicios de protección que quieren que su hijo sea institucionalizado porque se les salió de las manos y ya no obedece ni es posible su control, posiblemente están buscando un referente de autoridad que sienten que ya no pueden ejercer y que en la institucionalidad la podrían encontrar. De esta situación dan cuenta expresiones como:

"Vengo porque mi hijo se me está saliendo de las manos, no llega en las noches, no quiere estudiar, no hace caso, quiero que lo lleven al ICBF, que lo internen." (Comisaría de Familia, Localidad Santa Fe, septiembre de 2008) 
Son múltiples las motivaciones de padres y madres para desear internar a sus hijos e hijas en instituciones de protección: La desobediencia es quizás la de mayor frecuencia, el mal comportamiento, la rebeldía, la evasión del hogar, la evasión escolar, el temor a los diferentes riesgos sociales como abuso sexual, o consumo de sustancias entre otros.

Los conflictos con la autoridad que experimentan padres y maestros tienen su correlato en las relaciones que manifiestan los niños/niñas, jóvenes hacia ellos. Frente a la ambivalencia en el ejercicio de autoridad y control de los adultos, reclaman un nuevo trato familiar y escolar, mayor reconocimiento, inclusión en las decisiones, igualdad de condiciones y respeto al pleno ejercicio de sus derechos.

Así como los padres y maestros buscan apoyo en las instituciones de protección para regular las relaciones con niños, niñas y adolescentes, son también éstos, quienes en un nuevo estatus jurídico y social, reclaman de sus padres, sus maestros y del Estado el cumplimiento de las funciones que les garanticen sus derechos, solicitando a las instituciones de protección su deseo de cambiar de colegio o de ser institucionalizados, porque sienten que sus instituciones educativas o sus familias no les brindan cuidados, seguridad, educación, protección, alimentación o amor.

En la mayoría de los testimonios de niños, niñas y adolescentes registrados en las Comisarías de Familia de Bogotá durante los años 2006-2009, se evidencia su capacidad para tomar decisiones y rechazar y denunciar el maltrato:

"Yo no quiero volver a esa casa, quiero estar en Bienestar Familiar donde me sienta seguro". (Comisaría de Familia, Usaquén, octubre de 2008)

Deciden marcharse de sus hogares por la situación de pobreza buscando las instituciones de bienestar en la medida que allí les ofrecen la seguridad de contar con la alimentación diaria. ${ }^{4}$

Aprendieron que su permanencia en las instituciones educativas o de protección es itinerante en la medida que pueden entrar y salir según se modifican las condiciones familiares/escolares. Muchas veces las decisiones las han tomado o como una forma de denunciar las condiciones precarias en las que viven o

4. De ahí la importancia de señalar la necesidad de ofrecer políticas que combatan la pobreza en las ciudades como la propuesta en el Plan de desarrollo de Bogotá 2004-2008: Bogotá Sin Indiferencia. Un Compromiso Social contra la Pobreza y la Exclusión. 
como medida de apoyar a sus padres en situaciones de extrema dificultad y de pobreza o como un camino certero en el logro de sus metas, como el joven de 15 años que manifiesta su deseo de quedarse en un internado del ICBF para continuar los estudios y después seguir la carrera del ejército. (Comisaría de Familia, Suba, abril de 2008)

En los imaginarios de niños, niñas y adolescentes de estratos 1,2,3 de Bogotá, las instituciones que forman parte del Sistema Nacional de Bienestar Familiar, como el caso específico de las Comisarías de Familia significan una alternativa real de participación ciudadana, de restablecimiento de derechos, de apoyo en situaciones de riesgo y de inclusión social; además, las contemplan como un camino certero de resolución de problemas en la vida cotidiana y como un mecanismo a través del cual podrían cumplir sus proyectos de vida, pero al igual que en la casa y en la escuela algunos de ellos deciden evadirse.

¿Por qué se evaden los niños, niñas y adolescentes de los hogares, los colegios o las instituciones de bienestar? A través del relato de un niño de 12 años ejemplificaremos los motivos por cuales deciden evadirse, situación que bien podría aplicarse para cualquiera de las tres instituciones mencionadas: Porque estuvo expuesto a hurtos y no recibió ayuda de los adultos cuidadores, porque encontró indiferencia de su situación en los profesores, porque lo castigaron poniéndolo a hacer oficio, porque lo encerraron, porque la institución no tenía los espacios adecuados para el esparcimiento, porque no recibió atención médica ante un problema de salud, porque no contó con implementos de aseo, porque no recibió las raciones de comida que esperaba al día.

El niño que narra este episodio, solicita a la Comisaría enviarlo a otra institución de bienestar, que él considera de mayor reconocimiento en la medida que tiene información por amigos cercanos que allá ofrecen comida completa y posibilidades de continuar los estudios. (Comisaría de Familia, Localidad Suba, marzo de 2008)

La historia de este niño registra que se evadió de diferentes instituciones de protección durante nueve veces, pero además, registra evasión del colegio por acoso escolar y rechazo a su familia por maltrato de la madre.

Como se puede observar en este caso, el cuestionamiento del ejercicio de la autoridad no sólo se da en el espacio familiar, sino en la sociedad en general, 
donde adultos cuidadores y maestros ejercen estas funciones hacia la población infanto-juvenil; los diferentes escenarios sociales están reproduciendo el conflicto de autoridad tradicional versus autoridad contemporánea, profundizando el desencuentro en la relación con niños, niñas y adolescentes.

A continuación analizaremos las prácticas de disciplinamiento familiar y disciplinamiento escolar que conllevan a la postre a la exclusión social; en muchas circunstancias tales prácticas están asociadas a situaciones de desacato a la autoridad de padres o maestros o a problemas en las relaciones sociales como expresiones de maltrato, acoso o contravenciones infanto-juveniles.

Para la construcción de este apartado fueron fundamentales los testimonios de padres y madres de familia, participantes en las sesiones y la revisión de archivos con casos reportados por padres y maestros en las Comisarías de Familia consultadas. Las prácticas a las que nos referiremos son la evasión de hogar y la evasión escolar, el ausentismo, la suspensión, la desescolarización, la deserción y la expulsión.

\section{Figura 1. Prácticas de disciplinamiento o exclusión social en familia y escuela}

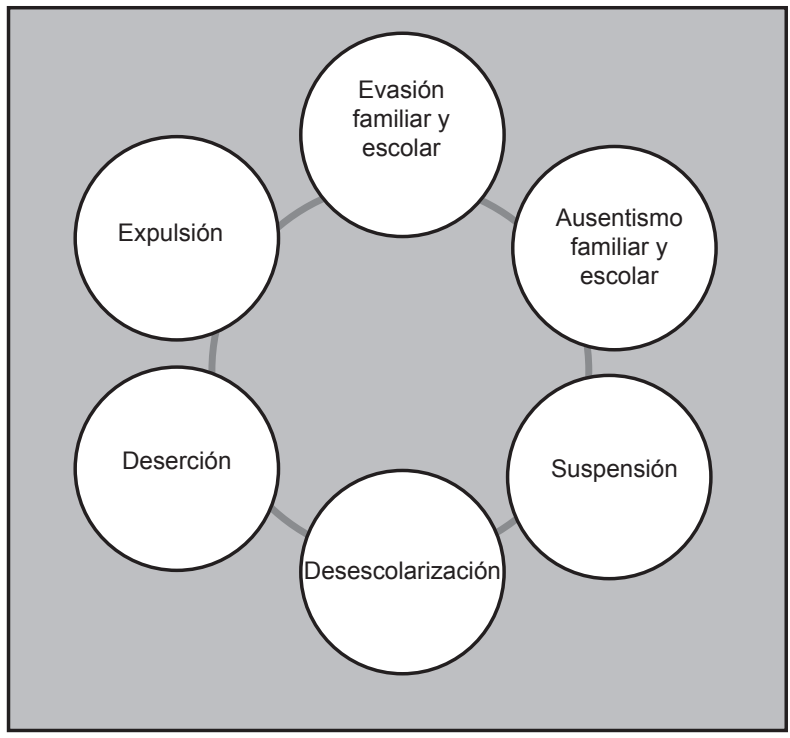

Fuente: Elaborado a partir de los datos recogidos 
Iniciamos el análisis sobre el tema de la evasión del hogar y la evasión escolar y las motivaciones que subyacen en estas decisiones que toma la población infantil y adolescente.

\section{La evasión del hogar}

Evadirse es escaparse a un orden social determinado porque no llena las expectativas de un sujeto. La evasión del hogar en la infancia o en la adolescencia, se constituye en una situación de riesgo social en la medida que dicha población se encuentra en proceso de formación. Evadirse tempranamente del hogar es fomentar las condiciones de exclusión social.

Por las lógicas internas de la evasión del hogar analizada a través de los testimonios de padres y madres de familia, niños, niñas y adolescentes, la evasión puede ser entendida como un elemento significativo en lo que Guerrero ha denominado "el proceso de autonomización de los jóvenes"; dicho proceso trae una novedad en los comienzos del siglo XXI y es que, si bien las anteriores revoluciones juveniles fueron predominantemente de jóvenes universitarios, los movimientos actuales tienen sus dinámicas en aquellos que cursan la secundaria involucrando cada vez grupos etáreos más temprano.

La familia y la escuela aún no están preparadas para asumir los cambios que la infancia y la juventud están tenido en medio de una revolución cultural de carácter global. Estamos viviendo un ciclo nuevo de las revoluciones de los jóvenes donde es cada vez más temprana la autonomización de los adolescentes. (Guerrero Barón, abril 2011)

Este proceso, de autonomización de los jóvenes, cifrado en su condición de ser sujetos de derechos, de ocupar un lugar en el espacio social, de tener voz y voto en las decisiones familiares, ha sido interpretado por aquellos que optan por la evasión, como el acto a través del cual manifiestan a su grupo familiar sus deseos, sus frustraciones, sus necesidades, sus angustias o sus temores; la evasión es un acto de emancipación temprana, la mayoría de las veces, para huir de la violencia familiar o escolar o para hacerse imaginariamente un lugar dentro de un nuevo grupo social: los amigos, la banda, el grupo, las relaciones de noviazgo en donde se sientan seguros, no juzgados, y con reconocimiento social. En otras ocasiones, la evasión del hogar está motivada por el miedo al no cumplimiento de sus responsabilidades escolares o las faltas éticas de los valores inculcados. 


\section{Figura 2. Motivos para la evasión del hogar}

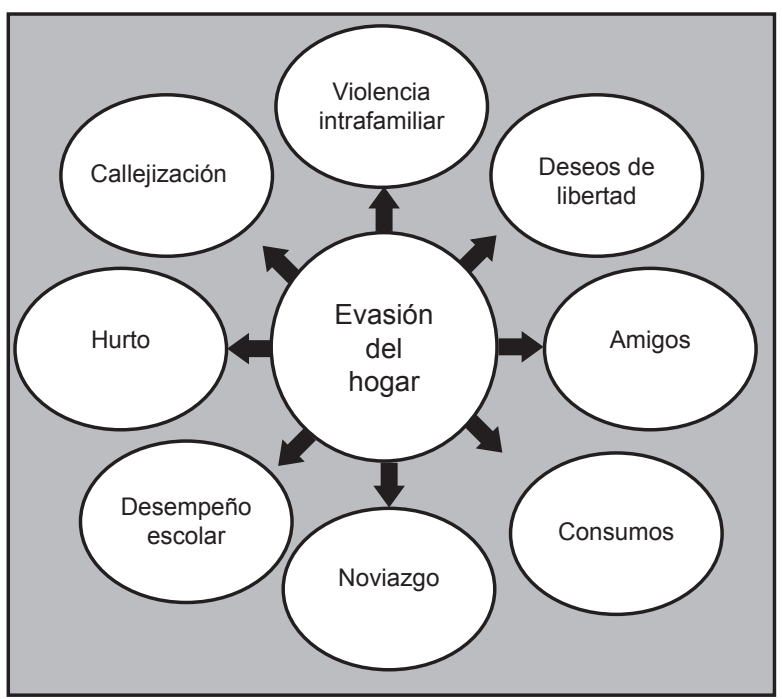

Fuente: Elaborado a partir de los datos recogidos.

Tanto la evasión del hogar como la evasión escolar se convierten en un riesgo social que alimenta la exclusión social. El informe 'Niñez Colombia' realizado en 2008 , señaló que cerca de $75 \%$ de los niños en situación de calle manifestó haber sufrido maltrato en su familia y $37 \%$ de ellos lo reconoció como el factor principal de su evasión del hogar. (Instituto Colombiano de Bienestar Familiar, 2008).

Expresiones como: "me fui de la casa por maltrato", son recurrentes en los archivos de las Comisarías y en los relatos de las familias: "mi hija de 14 años no cumplió las normas de la casa, el padrastro la trataba muy mal, le decía muchas groserías, yo nunca denuncié esa situación, y mis hijas mayores se fueron por tal razón". (Comisaría de Familia, Localidad Usaquén, marzo de 2008)

Así lo ratifica la adolescente:

[...] Tengo 15 años, curso noveno grado en la tarde, el año pasado mi papá me echó de la casa, y me fui por un día, él me buscó y cuando regresé, me pegó y ahora tenía miedo de que me volviera a pegar. (Comisaría de Familia, Localidad Usaquén, abril de 2008)

Igualmente se encontraron casos de evasión del hogar por alcoholismo de uno o ambos padres y violencia intrafamiliar asociada. En esta circunstancia, la eva- 
sión del hogar es una alternativa de los adolescentes para poner límite a la violencia ejercida por los padres, aun así esta decisión los enfrenta a otros riesgos sociales, entre ellos: la deserción escolar, el trabajo infantil, la delincuencia, los consumos y la violencia social generalizada.

Son recurrentes las frases entre los adolescentes reclamando 'libertad'. Libertad para hacer lo que ellos quieren sin límite y sin control.

Puede entenderse este llamado como una necesidad de reconocimiento ante sus padres y de posicionamiento en el grupo familiar; una adolescente de 15 años comenta que no quiere vivir con la mamá porque no le da la libertad que ella quiere y no puede salir cuando le pide un permiso. (Comisaría de Familia, Localidad Usaquén, junio de 2009)

Un elemento que influye con mucha fuerza en la toma de la decisión para evadirse del hogar son los intereses de los jóvenes que quieren vivir de manera intensa sin importar el tiempo que utilicen en ello y sin permitir que los padres se interpongan en sus planes, por ejemplo los gustos por la música, por el baile y por los consumos de sustancias psicoactivas como en el caso de la adolescente de 14 años que después de la jornada escolar, llegaba a la casa de 4 a 5 de la tarde, almorzaba y salía para la calle, regresaba a las 10 u 11 de la noche y a veces no llegaba a dormir; los viernes iba a bailar y no regresaba sino hasta el domingo o el lunes. Los padres de familia pusieron la queja en la Comisaría solicitando apoyo para que se colocaran límites a la adolescente, para que respetara los horarios de la casa y no se quedara por fuera de ésta. (Comisaría de Familia, Localidad Santa Fe, marzo de 2009)

Es importante señalar, en este caso, que los padres solicitaron ayuda para que la adolescente respetara las normas de la casa, más no pidieron ayuda para proteger a la adolescente que posiblemente estuvo expuesta a situaciones de alto riesgo social.

El consumo de alcohol en jóvenes es un factor de riego que cada vez cobra mayores víctimas; padres y madres se manifiestan desorientados frente a sus hijos que desde temprana edad y durante el proceso de escolarización, se inician en el consumo de cigarrillo, alcohol y otras sustancias. Así lo señaló la Encuesta Nacional sobre consumo de SPA en jóvenes de 10 a 24 años, en Colombia, realizada por RumBos en 2001, destacando que la edad de inicio del consumo de alcohol, para esa fecha, era a los 10 años y que el período de la vida en que mayormente se consumía era durante los estudios de secundaria. (RumBos, 2005) 
Un padre de familia relata que su hija de 14 años empezó con una actitud rebelde, sin acatar órdenes; un día la encontró en la casa con unos amigos; estaban tomando y habían hecho una bebida con alcohol etílico y se la estaban tomando, el padre llamó a la policía, pero éstos adujeron que no podían hacer nada; la joven se fue con los muchachos y actualmente está con ellos por voluntad propia. No quiso volver con los padres. (Comisaría de Familia, Localidad Usaquén, septiembre de 2007)

Diferentes estudios señalan que el inicio del consumo de alcohol se realiza con amigos en la propia casa o en la casa de los amigos. (Ministerio de Protección Social, Colombia, 2008)

Otro elemento de riesgo de la evasión del hogar, es cuando los adolescentes se marchan de la casa para unirse a grupos delincuenciales:

[...] Tengo una hija de 13 años, se fue hace 20 días de la casa, en el mes de julio se fue por cuatro días, anda con unos amigos que son una banda, ellos roban y la tienen para que les cargue los cuchillos y lo que se roban, la encontraron en otro barrio y llamamos a un agente de policía para traerla, pero él dijo que era caso de policía de menores, yo lo que quiero es que me den una orden para que cuando vea a un policía, él me pueda ayudar ya que la vamos a entregar al ICBF (Comisaría de Familia, Localidad Santa Fe, diciembre de 2007)

Un caso de evasión que nos llama la atención es el de una adolescente de 16 años que se marcha de la casa de los abuelos con el novio durante tres días y al regreso, los abuelos no la reciben; la joven vive algunos días en casa de sus amigas, pero luego decide presentarse a la Comisaría solicitando protección para que la envíen a algún sitio pues no tiene dónde vivir ni donde estudiar. (Comisaría de Familia, Localidad Santa Fe, agosto de 2008)

El bajo rendimiento académico y el temor a ser castigados, también se convierte en un motivo para evadir el hogar, evasión que puede ser horas o días, hasta que los mismos niños o niñas deciden comunicarse con sus padres o estos los encuentran por lo general en casa de algún amigo:

"Vengo porque mi hija de 15 años desde ayer al medio día 18 de junio no fue al colegio y no ha llegado a la casa. $Y$ hoy por la mañana tenía reunión de boletines y la niña no aparece desde ayer. (Comisaría de Familia, Localidad Usaquén, junio de 2009)

Otros casos revisados señalan situaciones de evasión asociadas a episodios de hurto menor en el hogar y a conductas de callejización, niños, niñas y adolescen- 
tes que permanecen mucho tiempo en la calle ausentándose de la casa y de las instituciones educativas. (Comisaría de Familia, Localidad Santa Fe, diciembre de 2007)

Como una tendencia en los casos analizados, encontramos que los jóvenes que evaden el hogar, mantienen vivo el interés de no abandonar los estudios y de buscar apoyos para continuar el proceso; aun así es difícil mantenerse en el proceso educativo sin los apoyos afectivos y materiales que ofrece la familia.

\section{Evasión escolar}

Nos referimos a la evasión escolar como la situación en que el niño, la niña o los adolescentes eluden las responsabilidades académicas, asistiendo de manera irregular a la institución educativa; en esta situación los estudiantes manifiestan en la casa, que asisten al colegio, pero una vez allí, no entran a clases o se fugan antes de terminar la jornada o permanecen en el colegio y se ocultan de los profesores para no ingresar a las aulas. Diversas situaciones intervienen en la decisión de un escolar para ausentarse de las aulas o de la institución. Padres y madres de familia reconocen como una tradición cultural escaparse de las escuelas o colegios saltando el muro antes de terminar la jornada escolar. Algunos padres, ex alumnos de las instituciones que hicieron parte de esta investigación, encuentran esta práctica totalmente natural y difícil de controlar. (Entrevista a la familia, Madre 007, 13 de febrero de 2009)

\section{Figura 3. Motivos para la evasión escolar}

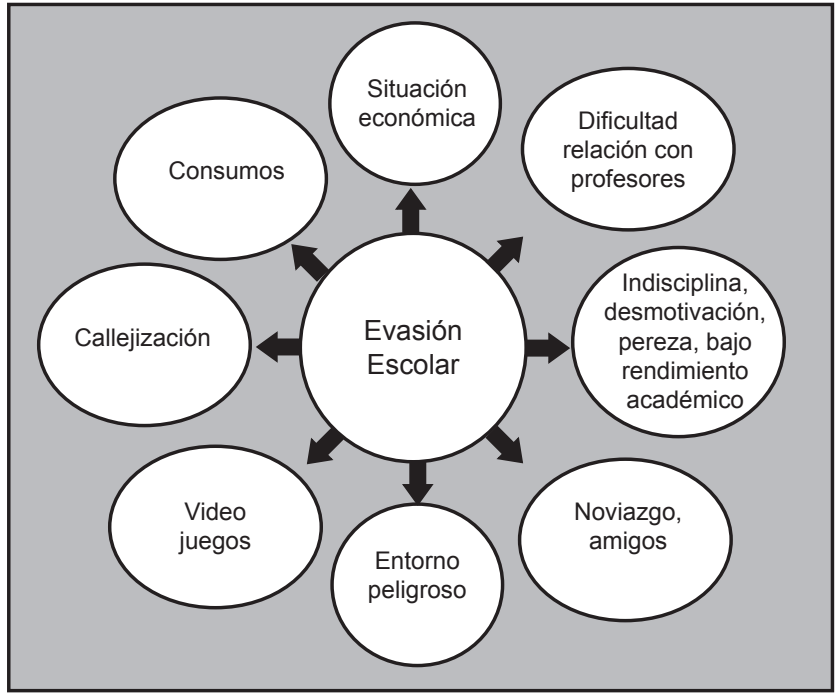

Fuente: Elaborado a partir de los datos recogidos. 
Encontramos solo un caso de una joven de 15 años que manifestó ante una Comisaría de Familia que no asistía a clases pues en el hogar no le daban las cosas que necesita para ir al colegio (Comisaría de Familia, Localidad Suba, junio de 2009)

Los casos reportados de evasión escolar relacionados con dificultades en la relación con los profesores también fueron escasos. Encontramos solo uno reportado por una madre de familia, en donde manifestaba que su hijo no entraba a las dos primeras horas de la jornada escolar por tensiones con la profesora (Sesión No. 1, Madre 029, 17 de abril de 2009)

La evasión escolar por problemas disciplinares es más recurrente. En este caso son los profesores quienes denuncian la evasión. Una institución educativa remitió a los padres y al menor a una Comisaría de Familia, solicitando que el menor de 14 años fuera diagnosticado y valorado por la indisciplina permanente, informando que éste no acataba las normas establecidas en la institución, ni en la casa y que constantemente faltaba a clases. EL profesor que remite dice:

"Este alto grado de indisciplina y desmotivación en lo académico se ha venido presentando reiterativamente en el tiempo que ha permanecido como estudiante en el colegio. Por favor indagar su historia familiar y personal para de esta forma poderles brindar un apoyo psicológico-terapéutico puesto que este estudiante lo amerita". (Comisaría de Familia, Localidad Suba, agosto de 2007)

Este tipo de remisiones sugiere preguntarse por el papel que desempeñan las instituciones educativas. También cabe preguntarse por la formación pedagógica de los docentes que los tendrían que preparar para asumir situaciones propias del oficio. El joven de 14 años, al que se refiere este caso, escolarizado en séptimo grado, manifestó en la Comisaría, que reconocía que se portaba mal, no hacía tareas, peleaba en el colegio, era agresivo con las profesoras y a veces no entraba a clases pues se la pasaba jugando maquinitas; le contesta mal a los papás, peleaba mucho con el hermanito pequeño y que, además, reconocía que no le gusta estudiar porque le toca madrugar. (Comisaría de Familia, Localidad Suba, agosto de 2007)

La desmotivación, es quizás el principal argumento de la evasión escolar, los niños, niñas y adolescentes entre los 10 y 15 años, manifiestan desmotivación, aburrimiento y pereza para asistir al colegio. Puede que vayan a la institución educativa pero no tienen deseos de realizar el trabajo escolar; los jóvenes mani- 
fiestan sentirse aburridos ante el estudio y ante las actividades de aula; prefieren invertir el tiempo en los videojuegos, escuchando música, estar con los amigos, fumar cigarrillo, vestirse como quieran y permanecer en la calle; padres y madres de familia experimentan sentimientos de impotencia cuando un hijo o hija les manifiesta su aburrimiento por el estudio; algunos de ellos deciden denunciarlos ante las Comisarías de Familia, en la búsqueda de una autoridad externa que los haga entrar en razón y les restituya el deseo por estudiar (Comisaría de Familia, Localidad Santa Fe, junio de 2009)

Así lo manifiesta un adolescente:

[...] Mi mamá pidió la cita para ver si yo vuelvo a estudiar, yo vivo con mi abuela materna y mi hermano de seis años". La madre aclara la situación del joven: "Mi hijo comenzó que no quería ir al colegio, dejó de hablarme y de recibir comida, yo estoy intentando hacer bien las cosas; para él quiero lo mejor y quiero dejar constancia de eso, yo le daba cuatro mil pesos para las onces y el día que no se los quise dar, dijo que no volvía al colegio y dejó de asistir; el papá actualmente no le está aportando económicamente para el sostenimiento. Mi hijo está repitiendo el grado séptimo ya que perdió el año y no lo volvieron a recibir porque tuvo problemas de indisciplina. (Comisaría de Familia, Localidad Suba, abril de 2009)

En este caso es evidente que el fracaso escolar, la indisciplina y la desmotivación, se constituyen en los principales componentes de la evasión escolar.

Otros de los argumentos para la evasión escolar están relacionados con la jornada escolar, siendo la tarde, la jornada que los jóvenes consideran menos adecuada para estudiar:

[...] Falté el viernes al colegio y esta semana porque no me gusta por la jornada de la tarde, cuando estudiaba en la mañana me quedaba más tiempo para hacer cosas, ahora no me gusta, no pongo atención y me regañan; la menor se compromete a seguir estudiando y solicita cambio de colegio y de jornada. (Comisaría de Familia, Localidad Suba, mayo de 2009)

En algunos casos, la peligrosidad del entorno barrial en donde está ubicada la institución educativa, influye en la decisión de los escolares para evadir la institución educativa. Un niño de once años reconoce que asiste irregularmente al colegio por el miedo que le produce desplazarse hasta el lugar en donde está ubicada la institución educativa, en sus palabras dice: "subir allá me da miedo porque no tengo ruta; mi hermano si tiene ruta, quiero estudiar en otro colegio 
cerca a la casa. Yo ya le había dicho a mi papá". (Comisaría de Familia, Localidad Usaquén, marzo de 2007)

El tener novio o novia durante el proceso escolar también puede convertirse en una situación de riesgo para la evasión escolar, sobre todo, si las viviendas de los jóvenes quedan distantes. Una madre denuncia su hijo porque no quiere seguir estudiando, le dice que va al colegio y no va; está con pereza de estudiar, no cumple con los deberes escolares, está fumando y no colabora con los oficios de la casa. El joven reconoce esta situación argumentando que el año pasado faltaba mucho al colegio, pues tenía una novia que vivía lejos de la casa y se la pasaba con ella todo el tiempo; faltó dos días semanales durante tres meses; el joven le solicitó a la madre que lo cambiara de colegio pero ella no aceptó. Este año sólo ha faltado dos veces, la primera se quedó fuera del salón y la segunda le dio pereza ir. Casi nunca hace tareas pues sólo realiza trabajos importantes. Fuma hace seis meses y aprendió eso cuando trabajó como vigilante, pues en las noches da sueño y frío. Reconoce que nada de esto es bueno y respecto a las labores domésticas no hace ninguna de ellas. (Comisaría de Familia, Localidad Usaquén, abril de 2007)

Otros casos de evasión escolar están asociados a las relaciones con los amigos con quienes realizan acuerdos para no asistir a la jornada escolar o para evadirse de la institución, para ir a jugar maquinitas en el barrio como lo expresa el relato de esta madre de familia:

[...] Ayer me dijeron que hay un niño que saca niños a las diez de la mañana por esta barda de acá, ¿sabe dónde estaban metidos? allá dónde hay unas cabinas que son un segundo piso, ahí, todos jugando; se van a jugar, el papá le da plata y la mamá le da plata, diez mil, veinte mil pesos, "el chino" se devuelve, y viene saca a la mayoría de niños y los lleva a jugar X-box. Entran a clase tres horas, y después de recreo ellos ya no regresan a clase, salen y se van. (Entrevista a la Familia, Madre 007 y 008, febrero de 2009)

Particularmente, este colegio es laxo frente a la permanencia de los niños y niñas durante la jornada escolar; los niños entran y salen, saltan la barda y no hay acciones de los profesores frente a este comportamiento. Igualmente, en este colegio, los padres de familia aceptan que cuando ellos fueron alumnos del plantel esta práctica de evadir el colegio, saltando el muro ya existía, por ello consideran que es una práctica culturalmente arraigada y difícil de controlar para los profesores. 
La evasión escolar por permanecer en la calle jugando maquinitas puede llevar, en ocasiones, a los niños, niñas y jóvenes a otro tipo de riesgos como unirse a bandas delincuenciales o iniciarse en los consumos. Un colegio denuncia a un estudiante de 14 años de edad del grado séptimo, quien fue remitido al servicio de orientación por reiteradas inasistencias a clases y bajo rendimiento académico.

El problema de la evasión de clases viene desde el año pasado y aunque de parte de los padres de familia y la institución se han intentado varias estrategias de concientización, éstas han funcionado temporalmente volviendo el joven a incurrir en la misma conducta cuando ya se disminuye el grado de vigilancia, porque se supone que ha regularizado su asistencia a clases, él reincide utilizando la misma técnica, sale de la casa diciendo que va al colegio y regresa a la casa en la tarde. En dialogo con el joven, él no da explicaciones a su conducta y simplemente dice que se queda en la calle dando vueltas, viendo futbol o jugando videojuegos. La madre de este niño acepta que su hijo consume bóxer por lo que decide reportarlo a un Centro de Emergencia. Igualmente, se encontraron casos de evasión escolar por consumo de alcohol en los y las adolescentes. (Comisaría de Familia, Localidad Suba, agosto de 2007)

\section{Ausentismo escolar}

Consideramos el ausentismo escolar como la inasistencia prolongada a la institución escolar. A diferencia de la evasión, el estudiante interrumpe la asistencia a la institución educativa por periodos consecutivos. Puede ser por voluntad propia del estudiante o por que las circunstancias así lo determinan.

Cuando la evasión escolar no es atendida a tiempo, ésta puede configurarse en ausentismo escolar; es decir, faltas reiteradas que ponen en peligro el proceso académico. Algunas circunstancias que desencadenan el ausentismo escolar están relacionadas con la vida familiar, su composición, la calidad de las relaciones, y el cuidado de padres y madres sobre los hijos e hijas.

Un niño de once años relata que al estar bajo la custodia del padre, perdió el interés por el estudio, ya que su padre no le daba ninguna atención y apoyo llegando a faltar dos meses consecutivos al colegio sin que él se diera cuenta; durante ese período pasaba el tiempo escolar en la calle jugando maquinitas; el tratamiento que le dio el colegio fue expulsarlo, razón por la cual la madre se enteró y tuvo que buscar un nuevo colegio para el niño. (Comisaría de Familia, Localidad Santa Fe, diciembre de 2007) 
Es frecuente encontrar historias de niños y niñas que iniciaron evadiendo la institución escolar por dedicarse a los videojuegos como el XBOX y que ante la escasa orientación y ayuda de padres, madres y maestros, los niños y jóvenes terminaron ausentándose por períodos prolongados de sus casas y de sus colegios.

Esta situación se agudiza si se tiene en cuenta que en el escenario barrial se encuentra todo tipo de establecimientos cercanos a los colegios que ofrecen venta de servicios no adecuados para la población infantil y juvenil como los videojuegos y los consumos de alcohol y otras sustancias. Muchos de estos negocios cierran las instalaciones una vez se llena el cupo del establecimiento, para que niños y jóvenes no sean visibles ante la policía o adultos que puedan denunciar.

Algunas madres reconocen que sus hijos prefieren quedarse en la calle jugando XBOX. (Comisaría de Familia, Localidad Santa Fe, diciembre de 2007)

Igualmente, los adolescentes que han estado en riesgo de calle admiten que los video-juegos sin control se convierten en el mayor riesgo de fracaso escolar:

"Sí, es cierto que yo andaba con un amigo y nos íbamos a jugar XBOX. Venía a veces tarde. Él no siguió estudiando pero ahora yo me comprometo a portarme bien y seguir estudiando, también a obedecerle a mi mamá y no tener malas amistades". (Comisaría de Familia, Localidad Santa Fe, junio de 2009)

¿Cómo asumen los profesores el ausentismo escolar? En uno de los colegios que participó en esta investigación, se expresó que era poco lo que los profesores podían hacer frente al ausentismo escolar, esta actitud es aceptada pasivamente por padres y madres de familia justificando el hecho que los profesores no salgan a buscar a quien se fue, con argumentos como que "los profesores tienen cuarenta alumnos y por uno no van a dejar treinta y nueve tirados, porque hay treinta y nueve que quieren estudiar y por uno solo que no quiere estudiar, cómo van a dejar el salón tirado por salir a buscarlo. Como en la propaganda "a buscar al niño", pero ¿si el niño no quiere estudiar? (Entrevista a la familia, Madre 007 y 008, febrero de 2009)

Argumentos como este, justifican el hecho que si un hijo no quiere estudiar no se le puede obligar, como si se tratara de respetar ese deseo del niño frente a la decisión de estudiar o no". (Entrevista a la familia, Madre 007 y 008, 13 de febrero de 2009) 


\section{Suspensión escolar}

Entendemos por suspensión escolar la sanción disciplinaria que aparta a los estudiantes de la asistencia a clases por un período de tiempo corto. La suspensión escolar implica que el estudiante debe cumplir con ciertas tareas en la casa, las cuales deben ser reportadas al colegio. A diferencia de la evasión y del ausentismo escolar en donde interviene la voluntad de cada niño/a o joven para no asistir a la institución educativa, en la suspensión escolar la decisión es tomada por los directivos de las instituciones o los profesores. Con la suspensión escolar se espera involucrar a las familias en el proceso de disciplinamiento de niños/as y jóvenes; es una especie de alerta para las familias que indica que el desarrollo educativo del estudiante tiene problemas.

Esta práctica es común en los países de la región y se manifiesta con características similares al contexto nacional. Según investigaciones en México, la suspensión es otro mecanismo muy utilizado por los maestros; dicha práctica es aplicada con diferente duración y "en algunos casos, puede ser definitiva". (Gómez Nashiki: 710)

Además, es una práctica asociada a sanciones por hechos de violencia escolar en donde la "solución o respuesta de los maestros y autoridades educativas siempre se orientó a la suspensión temporal o definitiva del alumno del plantel, lo que se traduce en que, quien practica estas conductas, se desplaza a otros ámbitos de acción". (Gómez Nashiki: 712)

Ante la pregunta a padres y madres de familia de Bogotá, sobre las medidas disciplinarias que implementa el colegio cuando el hijo o hija comete alguna infracción, encontramos con frecuencia respuestas de este tipo:

"Los suspenden uno o varios días de clase y llaman a los acudientes para que nos los llevemos para las casas" (Encuesta a la familia, Madre 018, marzo de 2009)

O "los suspenden o los ponen a hacer ejercicio o los mandan a recoger papeles del patio por un mes". (Sesión No. 5, NES Familia, Padre 002, marzo de 2009)

Un padre de familia expone el proceso disciplinar que se aplica en el colegio donde estudian sus hijos: a) se analiza la problemática o el inconveniente, b) a los inconvenientes pasajeros les dan solución rápida, c) se revisan los antecedentes 
del estudiante si tiene un proceso y hasta implicaciones jurídicas del mismo, d) se adelanta la Investigación del caso, e) se toman correctivos pertinentes con los directos implicados, f) vine la amonestación, las sanciones para ir acumulando la hoja de vida. Las sanciones pueden ser la suspensión disciplinaria según la falta cometida. (Sesión No. 5, NES Familia, Padre 002, marzo de 2009)

Algunos padres y madres reconocen que sus hijos han sido castigados con la suspensión escolar por mal comportamiento, como en el caso de esta madre que comenta que los profesores le dijeron que no podían tener más a su hijo en el colegio, o que se lo llevaba o que lo expulsaban; en este caso la madre prefirió retirar los papeles del colegio y buscarle cupo en otra institución educativa en sexto grado. (Comisaría de Familia, Localidad Suba, septiembre de 2008)

\section{Desescolarización: modalidades}

Es necesario aclarar que con respecto a la categoría "desescolarización" el lector se encontrará con por lo menos tres modalidades sobre la misma.

En primera instancia se encuentra la propuesta de desescolarización formulada por Iván Illich, en la década de los setenta; dicha propuesta contemplaba que no sólo las instituciones sino el ethos de la sociedad debían ser desescolarizados, pues consideraba imposible pensar la educación universal a través del mecanismo de la escolarización, afirmando que ni en Norteamérica ni en América Latina los pobres lograron la igualdad a partir de las escuelas obligatorias. (Illich, 2006: 189-323)

En sus palabras, la desescolarización de la sociedad implicaba:

[...] El reconocimiento de la naturaleza ambivalente del aprendizaje. La insistencia en la sola rutina podría ser un desastre; igual énfasis debe hacerse en otros tipos de aprendizaje. Pero si las escuelas son el lugar inapropiado para aprender una destreza, son lugares aún peores para adquirir una educación. La escuela realiza mal ambas tareas, en parte porque no distingue entre ellas. La escuela es ineficiente para instruir en destrezas por ser curricular. En la mayoría de las escuelas, un programa cuyo objetivo es mejorar una habilidad, está siempre concatenado a otra tarea no pertinente. (Illich: 12)

Para Illich, la desescolarización estaba relacionada directamente con el verdadero "movimiento de liberación del hombre", en donde la formación se lograría a 
través del auto aprendizaje, por medio de encuentros informales e intencionados que desataran el deseo de saber o lo que él denominó el 'aparejamiento intelectual". (Illich, 2006: 16-29)

Sus propuestas fueron críticas respecto a la educación obligatoria y gratuita; consideramos que muchos de sus argumentos han sido recogidos por los partidarios de la nueva tendencia mundial de la educación sin escuela.

En segunda instancia, se encuentra la tendencia mundial surgida en la década de los 90, en el mundo de occidente, sobre la desescolarización de niños, niñas y jóvenes por voluntad propia de las familias quienes se encargan de llevar a cabo la educación de los hijos/as en casa. A este movimiento también se le conoce como "educción libre", "educación en casa", "educación en familia" o "homeschooling". ${ }^{5}$ Es importante señalar que los orígenes de la educación en casa "se encuentran en la educación doméstica ofrecida por las familias antes del surgimiento de la escuela republicana y que durante 19 siglos fue la forma expedita como las familias educaron sus hijos/as". (García, S, 2007: 174)

El movimiento actual, representa la renovación de una práctica muy antigua que puede ofrecerse hoy con mayores niveles de educación de padres y madres de familia, con una organización social que ofrece múltiples formas de aprender, con mayores capitales escolares, culturales y sociales en circulación, que están disponibles a todo tipo de aprendizajes desde edades muy tempranas.

Respecto a la “'educación en casa”' contemporánea, algunos expertos señalaban que:

[...] El Homeschool (escuela en casa) es una tendencia que acogen miles de familias en el mundo. En Estados Unidos, la Oficina del Censo registró el crecimiento de 600 mil familias a inicios de los años 90, a casi millón y medio hoy en día, según se dijo en el Seminario Internacional La Educación en Ciencias Sociales, que realizó la Universidad Nacional. En Colombia, a pesar de que existe esta práctica, no hay registros oficiales. En el Ministerio de Educación se aseguró que el tema aún no ha sido abordado por la entidad. En Colombia unas 50 familias educan sus hijos en casa. ( Patiño G, 2011)

5. Ver la página de la Asociación para la Libre Educación, ALE. Disponible en: http://www. educacionlibre.org/inicimarc.htm, consultado 2/07/2011. También se puede consultar el Blog: La opción de educar en casa. Disponible en: http://madalen.wordpress.com 
La ideología de dicho movimiento es una alternativa frente a las inconformidades de las familias con la educación escolarizada tal y como es ofrecida por los sistemas educativos contemporáneos; una experta española en el tema así lo considera:

[...] Es una ideología alternativa, ligada a principios de tipo ecologista, de conservación del medio ambiente, de corte antiautoritario, anti patriarcal y anticapitalista además de contrario en general a una vida sumida en el consumo, incluyendo en ese consumo el abuso de la televisión. Parece mostrar una tendencia a favorecer el contacto con la naturaleza, como forma ideal de vivir en familia, lo rural frente a lo urbano y el trabajo físico y manual sobre el intelectual. Es una ideología austera en cuanto a la utilización de los bienes de consumo, capaz de adaptarse a la vida prescindiendo del trabajo remunerado de por lo menos uno de los progenitores, y por último, en cuanto a la salud física, una vida unida al higienismo, el vegetarianismo en sus diferentes variables y la permacultura. (Goiria, 2009)

Este movimiento mundial de padres y madres conscientes de la importancia de la formación de niñas y niños, puede generar cambios estructurales en los sistemas educativos contemporáneos que implicarían: nuevas pedagogías, uso diferente del tiempo, costos educativos más racionales, transformaciones en la administración del servicio educativo, nuevos aprendizajes y nuevas sociabilidades, entre otros.

En tercera instancia, se encuentra la desescolarización como una práctica disciplinar de sanción escolar, ejercida desde los maestros hacia los y las estudiantes mediante la cual los niños, niñas y jóvenes son separados de las clases con el objetivo que realicen el trabajo académico en la casa, la mayoría de las veces por mal comportamiento o problemas convivenciales. Es una modalidad muy usada en los colegios con una duración de, según los datos recogidos, una semana hasta tres meses, período en el cual el estudiante debe desarrollar guías académicas en casa y reportarlas periódicamente al colegio. A diferencia de la práctica de la suspensión escolar, la desescolarización es más prolongada en el tiempo, pero siempre es temporal, de lo contrario se convertiría en expulsión escolar.

En este apartado nos referiremos a la práctica de la desescolarización como sanción disciplinaria ejercida en los colegios, teniendo en cuenta los datos empíricos recogidos en cinco instituciones de Bogotá a través de testimonios de padres y madres de familia, maestros, niños y jóvenes y en los registros de los archivos de las Comisarias de Familia. 


\section{Desescolarización: falta disciplinaria por irrespeto a la autoridad del maestro}

Ante la pregunta a padres y madres de familia sobre las medidas disciplinarias que implementa el colegio cuando los niños y niñas cometen alguna falta, la mayoría de respuestas están relacionadas con la desescolarización. (Entrevista a la familia, Madre 013, febrero 2009)

Encontramos en un colegio, el caso de una estudiante que fue desescolarizada por problemas de convivencia tales como: desacato a las normas, llegar tarde, pelearse con las compañeras, agredir e irrespetar a los maestros, pero según los datos recogidos, la mayor falta que se sancionó, en este caso, fue el irrespeto a los maestros. (Entrevista a la orientadora 002, febrero de 2009)

Según la orientadora de un colegio, la estudiante Ximena de octavo grado estuvo en proceso de desescolarización durante tres meses en el año 2008; ella sólo tenía que ir al colegio a dejar las tareas escolares y a presentar las evaluaciones, usualmente la mamá o una de las hermanas iba a acompañarla. De esta manera terminó el octavo grado. Ximena fue desescolarizada junto con otra compañera del curso, la cual no logró aprobar el año académico porque no contó con el acompañamiento de la familia; a Ximena le ayudaban en casa con las taras escolares y con el cumplimiento de los compromisos a tiempo, lo que le permitió obtener todos los logros académicos. Al siguiente año Ximena fue recibida nuevamente en el colegio, pero con un compromiso convivencial a pesar que se reconoció que ella no era una niña catalogada como terrible; su mayor problema radicaba en que se enfrentaba con los maestros y les contestaba. (Entrevista a la orientadora 002)

Al comenzar el año 2008, se establecieron unos acuerdos y compromisos para la estudiante, dándole un plazo de seis meses para que demostrara su buen comportamiento, no agrediendo a sus compañeras, llegando puntual a clases y respetando a los profesores, pero no cumplió; ella sabía que si incumplía, el paso siguiente sería la desescolarización y efectivamente así pasó. Los padres de familia de Ximena consideran que la sanción de desescolarización de su hija ha sido la experiencia más fuerte que ha tenido la niña durante el proceso escolar. "La niña venía presentando mal comportamiento. La mandaron para la casa y, al parecer, en el colegio consideraron que era conveniente sacarla por un tiempo; para Ximena fue un sacudón muy fuerte pues se preguntaba por qué la habían sacado, queriendo volver cuanto antes". (Encuesta a la familia, febrero de 2009) 
Durante el periodo de desescolarización los padres observaron que la niña estuvo triste, pensativa y sin ánimo de arreglarse. Según la madre, las explicaciones del colegio para entregarle la niña fueron: "no nos la aguantamos".

Al indagar por el proceso realizado en el colegio, se evidenció que se cumplieron los conductos regulares estipulados en el manual de convivencia para sancionar faltas como las que le fueron tipificadas a la estudiante: llamada de atención del coordinador del grupo, llamado de atención de otros maestros, citación a orientación, citación a coordinación académica, estudio del caso y finalmente, la toma de decisión de la sanción disciplinaria: desescolarización por tres meses.

En este caso es claro, como en muchos otros, que en la aplicación de las sanciones disciplinarias sigue pesando de manera importante el restablecimiento de la autoridad del maestro o como lo dijera Parra Sandoval en 1986: "Las faltas que más se sancionan son las que hacen referencia a la relación con los profesores, como por ejemplo que un alumno responda en tono fuerte, o diga algo que desagrada al maestro". (Parra Sandoval, 1986)

\section{Desescolarización por maltrato físico leve entre compañeros}

Se encontró un caso de desescolarización de un estudiante de noveno grado, durante un mes, por una falta de maltrato escolar físico leve. Al preguntarle a la madre de familia, por la duración de la desescolarización, ésta dijo: "la profesora me dijo que un mes, dos meses, lo que a ella se le diera la gana hasta que no acabara de entregar todos los trabajos y recibiera el visto bueno de todos los profesores". (Sesión No. 3, mayo 2009)

El joven fue presionado por otros estudiantes del curso para que agrediera físicamente a un compañero y así demostrara su hombría. Esta agresión la catalogamos como maltrato físico leve en la medida que no produjo daño físico en la víctima y el hecho fue ocasional. Por este evento, el joven fue desescolarizado a pesar de la insistencia de la madre de familia a la profesora para que no se aplicara dicha sanción, teniendo en cuenta que no tenía ni cómo apoyarlo ni cómo cuidarlo durante la desescolarización, pues tanto ella como su esposo, trabajaban de tiempo completo fuera de la casa.

El joven asumió la sanción con rabia pues consideraba injusta la medida escolar; él le dijo a la profesora delante de la madre de familia: "hay niños que han hecho 
peores cosas que yo y ¿cómo usted no los sanciona? ¿Por qué me tiene bronca a mí? Por qué para usted siempre el dedo malo soy yo, cualquier cosa que pase en el salón soy yo, dígame profe ¿por qué me tiene tanta bronca?". (Sesión No. 3, mayo 2009)

Madre y joven reconocen que en el colegio se cometen toda clase de infracciones como fumar cigarrillo, marihuana y otras drogas, porte de armas, hurtos, y todo tipo de agresiones que no son sancionadas con medidas como la desescolarización.

Ante la situación de malestar del hijo, la madre de familia le propuso cambiarlo de colegio, propuesta que fue rechazada por el joven con el argumento: "yo tengo mis amigos allá y allá estudio, yo quiero graduarme de ese colegio si me dan la oportunidad y si no, no". (Sesión No. 3, mayo 2009)

Durante el proceso de desescolarización del joven, la vida cotidiana de la familia se afectó, pues ello produjo enfrentamientos entre la pareja por el ejercicio de la autoridad parental, desajustes en los horarios laborales de los padres y riesgos mayores para el hijo al dejarlo solo cada día en internet sin guía ni acompañamiento para que hiciera las tareas.

La madre consideró que si su hijo cometió la falta era necesario aplicar una sanción, pero no impidiéndole asistir regularmente al colegio. Ella sugería que si el castigo era ponerle más trabajo académico, estaba de acuerdo siempre y cuando lo hiciera alargando la jornada académica, más no sacándolo del colegio.

\section{Desescolarización por moda y rebeldía adolescente}

Presentamos a continuación el caso de un adolescente de 13 años quien empezó presentando episodios de evasión del hogar, evasión escolar y luego de desescolarización con riesgo de deserción.

El joven pertenece a una familia nuclear disuelta; a raíz de la separación de los padres, la madre y su hermana menor se fueron a vivir con la abuela materna y el padre con sus padres. La madre del menor manifestó:

[...] estamos separados hace dos años porque ingresamos a la universidad y cada quién cogió su rumbo, el señor consiguió otra persona, él se fue para donde los papás y yo para donde mi mamá, él muy poco los llamaba o 
los veía, yo también los descuide y los niños quedaron a cargo de la abuela durante el día”. (Comisaría de Familia, Localidad Suba, junio de 2009)

La madre refiere los cambios que ha percibido en su hijo desde que este tenía 12 años, "se deprime mucho y es muy irritable, se ha cortado sus brazos en diferentes oportunidades y amenaza con quitarse la vida cuando se siente muy presionado por los sucesos familiares, a veces es muy contento, alegre, expresivo y a veces es muy agresivo, no quiere salir del cuarto, no quiere hablar con nadie y se pone muy grosero conmigo y con mi mamá". (Comisaría de Familia, Localidad Suba, junio de 2009)

El joven se vinculó con un grupo de amigos que pertenecían a la cultura emo y ello le significó cambios en su manera de ser y de relacionarse. Al respecto la madre comenta que desde inicios del 2009 , no sabe si por moda o por influencia de los amigos con los que comparte, se viste como Floyd, usa el cabello de lado, no tiene un color definido de ropa, usa tres piercing en la cara, el año pasado decía que era Emo, usa pantalones apretados, los amigos que tiene usan la misma vestimenta y lo que ve es que sus amigos tienen los mismos conflictos que él, hijos de padres separados, de familias conflictivas, de pobrecito soy yo; una de las amigas que le presentó a los amigos le comentó que un tío suyo se había suicidado y eso marcó mucho a este grupo de amigos. (Comisaría de Familia, Localidad Suba, junio 2009)

Además el joven manifestó tendencias homosexuales. La madre se dio cuenta por mensajes que le llegaban al celular; haciendo el seguimiento de esta relación, se dio cuenta que había entablado una relación amorosa con un estilista mayor de edad; al comienzo su reacción fue de rechazo, pero hablando con el novio de su hijo descubrió que es una buena persona, trabajador y que por el contrario le daba buenos consejos acerca de la prevención de consumo de sustancias psicoactivas.

A su vez, el padre no aceptó las tendencias sexuales de su hijo y ello significó conflictos familiares, agresiones físicas mutuas, intolerancia, irrespeto y denuncias ante la policía y el Bienestar Familiar.

Respecto al proceso educativo del joven, la madre refiere que este año no está estudiando y por ello se han agudizado los problemas con el padre, además de no aceptar su condición homosexual. Por toda esta circunstancia emocional, familiar y escolar del joven, la madre decidió consultar con un psiquiatra. 
El joven estuvo matriculado en otro colegio de la localidad, desde transición hasta el séptimo grado, pero tuvo que retirarse por su rebeldía, porque no aceptaron su forma de peinar su cabello y los piercing, allá también tuvo su primer intento de suicidio pero fue porque unos niños del curso le dijeron que él no era capaz de suicidarse y él les dijo que sí y se fue hasta el $4^{\circ}$ piso para tirarse al vacío, pero los demás estudiantes llamaron al psicólogo e impidieron que esto pasara; por ello fue remitido al hospital de la localidad y estuvo en tratamiento con un psicólogo durante tres meses. Ingresó a otro colegio privado de la localidad a cursar el grado $8^{\circ}$, el cual cursó hasta mediados del año ya que después de vacaciones no regresó, fue sólo un día pues citaron a la madre para decirle que "no lo recibían con el cabello largo y con el piercing porque si se lo aceptaban a él tenía que aceptarle al resto de los alumnos", ante la notificación del colegio, el joven dijo que no se iba a cortar el cabello y que prefería no volver. (Comisaría de Familia, Localidad Suba, junio de 2009)

El rector le dio la opción de que continuara estudiando de forma no presencial, debiendo presentar trabajos y evaluaciones periódicas, pero el joven no ha respondido a este compromiso aunque reconoce que "quiere estudiar pero que en el colegio lo presionan mucho por su forma de ser y su forma de pensar pero igual no se compromete"; ante el riesgo que presiente la madre del abandono del proceso educativo de su hijo o que no encuentre el colegio apropiado para él, le propone buscar un nuevo colegio que ofrezca educación alternativa, pues considera que su hijo "ha sido muy buen estudiante, el problema siempre ha sido su comportamiento y su apariencia”. (Comisaría de Familia, Localidad Suba, junio 2009)

La relación madre e hijo ha sido difícil, la señora manifiesta su interés de apoyarlo y entenderlo pero reporta que su hijo es muy agresivo, no respeta normas, se ha quedado por fuera de la casa sin permiso, otras veces con permiso, le preocupa que en ocasiones percibe que las amenazas de él buscan en cierta forma manipular su situación, pero reconoce que su hijo tiene muchos problemas y teme que haga efectivas sus amenazas de suicidio.

Según el reporte de psiquiatría se conceptuó que él joven no tenía ningún trastorno mental, que lo de rayarse los brazos no era depresión sino moda y que muchos de los comportamientos que presentaba se relacionaban con su proceso de identidad. El psiquiatra recomendó que el joven tuviera tratamiento psicológico y que continuara estudiando.

El menor reconoce que a veces tiene un genio difícil, actualmente no está estudiando, asiste a clases de inglés los sábados, quiere estudiar el próximo año, 
comprende que no debe ser agresivo con sus familiares. La Comisaría de Familia, establece la necesidad de definir acuerdos respecto a manejo de tiempo libre, horarios, colaboración del hijo en la casa entre otras. (Comisaría de Familia, Localidad Suba, junio de 2009)

\section{Deserción escolar}

La deserción escolar hace referencia al abandono del proceso escolar lo cual conlleva al retiro del sistema educativo. La deserción se entiende como el abandono de los estudios antes de concluir un grado o un nivel (Se entiende por deserción intra-anual, aquella que sucede durante el año escolar, es decir es la diferencia entre la matrícula inicial y final del año escolar. Deserción interanual es aquella que sucede entre un año y otro). (CORPOEDUCACIÓn, 2006)

Existe consenso mundial en cuanto a que la pobreza se convierte en el principal factor para que niños y niñas deserten de la escuela. La encuesta sobre pobreza realizada por UNICEF en 2004 "destaca que el 77\% de los niños y niñas que no acuden a la escuela primaria provienen del $60 \%$ de los hogares más pobres de los países en desarrollo, con niveles más elevados en América Latina y el Caribe (84\%), y África oriental y meridional (80\%)." (Monclus \& Saban, 2006: 98)

La población en mayor riesgo de estar por fuera del sistema educativo es la adolescente, "entre los 7 y 12 años, casi la totalidad de los niños van a la escuela. A partir de los 13 años comienza a observarse una proporción mayor de adolescentes fuera del sistema educativo. Este proceso se acelera al punto que a los 16 años, uno de cada cuatro adolescentes se encuentra desescolarizado". (Sistema de información de tendencias educativas en América Latina, 2009: 1)

En la década de los 90, el sistema educativo latinoamericano es impactado por procesos simultáneos: La llegada de numerosos niños y jóvenes a las escuelas básicas debido a esfuerzos sostenidos por los gobiernos de ampliación de cobertura educativa y de otra parte el llamado "bono demográfico" consistente en la disminución de la población de niños en educación primaria lo que permitió ampliar la cobertura de la educación secundaria. ${ }^{6}$

Pero este proceso de ampliación de la cobertura en la secundaría ha sido un fenómeno mundial:

6. El efecto de las gestiones de los organismos multilaterales liderados por la ONU con motivo de la programación de los pactos y para la concertación de los objetivos del desarrollo del milenio, un ambicioso plan de equidad y desarrollo humano para el período 2000-2015, que se plantea en el objetivo No.2 la enseñanza primaria universal. 
[...] En los últimos 50 años, el número de estudiantes de educación secundaria a nivel mundial ha aumentado de 40 a 400 millones... Las escuelas se han visto en serios apuros para mantenerse al mismo ritmo de este enorme crecimiento; el tamaño de la clase ha aumentado sustancialmente... Esta expansión afecta la calidad de la enseñanza. El aumento de las matrículas ha ido acompañado de un aumento en los niveles de fracaso académico... En América Latina, todos los años, prácticamente un tercio de los alumnos deben repetir un grado. (UNESCO, enero-marzo de 2003: 5)

En el ámbito nacional el panorama es preocupante en cuanto a los niveles de deserción.

Según las cifras del Ministerio de Educación Nacional, en 2002 cerca de 606.000 niños, niñas y jóvenes desertaron del sistema por razones asociadas a la escasez de recursos de las familias para sufragar los costos educativos, al desplazamiento provocado por la violencia entre 1995 y 2004 , al fracaso escolar y a la repitencia escolar. A esto se agrega que muchos niños y jóvenes consideran que la escuela no les está aportando para su vida. (CORPOEDUCACIÓn, 2006: 72)

La encuesta calidad de Vida del año 2003 señaló que la reprobación y la deserción es alta en $1^{\circ}$ y $6^{\circ}$ grados ( $8 \%$ y $7 \%$, respectivamente), asociando los dos factores como elementos desencadenantes de la deserción escolar. Igualmente, tanto en el nivel rural como en el urbano, la repetición de cursos, es muy elevada en primer y sexto grados. (CORPOEDUCACIón, 2006: 73)

Al respecto, es importante recordar que las investigaciones sobre violencia escolar coinciden en que la mayor exposición a violencia escolar, la viven los niños y los adolescentes, precisamente, en el período de transición de la escuela primaria a la secundaria, es decir en sexto grado y al finalizar está en undécimo grado.

El riesgo de deserción es mayor en el género masculino, así lo señala el estudio adelantado por CoRPOEDUCACION en 2006: "los hombres siempre superan a las mujeres en aproximadamente dos puntos porcentuales. Igualmente, se observa que el patrón de esta deserción es bastante similar en ambos sexos: los porcentajes más elevados se presentan en los grados primero y sexto y el más bajo en el grado decimoprimero" (CORPOEDUCACIÓN:2006:76)

Según los datos comparativos sobre las razones para no estudiar en Colombia entre 1997 y 2003, se encontró como significativo en ambos períodos en primera instancia razones económicas y en segunda, a los niños/as y jóvenes entre 11 y 17 años no le gusta o no le interesa el estudio tanto en la población rural como en la urbana. 


\section{Cuadro 1. Razones para no estudiar en Colombia: población de 5 a 17 años 1997 y 2003}

\begin{tabular}{|l|r|r|}
\hline \multicolumn{1}{|c|}{ ¿Por qué razón no estudia? } & $\%$ & $\%$ \\
Costos educativos elevados o falta de dinero & 1997 & 2003 \\
No le gusta o no le interesa el estudio & $33 \%$ & $46 \%$ \\
Considera que no está en edad escolar o que ya terminó & $20 \%$ & $20 \%$ \\
Necesita trabajar & $10 \%$ & $7 \%$ \\
No existe centro educativo cercano & $7 \%$ & $6 \%$ \\
Otras razones & $5 \%$ & $4 \%$ \\
Falta de cupos & $24 \%$ & $17 \%$ \\
Por enfermedad & $4 \%$ & $3 \%$ \\
Falta de tiempo & $4 \%$ & $2 \%$ \\
Responsabilidades familiares & $4 \%$ & $1 \%$ \\
otro & & $6 \%$ \\
\hline
\end{tabular}

Fuente: Encuesta de Calidad de Vida - DANE 1997 y 2003. (Procuraduría General de la Nacional, 2006: 118, 119)

En cuanto a la deserción escolar según el tipo de establecimiento educativo, se encontró que mientras en las instituciones educativas privadas el número de estudiantes que cursa undécimo grado representa el $60 \%$ de los que iniciaron primer grado, en el sector público ese porcentaje desciende al 22\%. (Cuatro estrategias para la repitencia y la deserción, consultado abril de 2011)

Según el MEN, en 2010, la tasa de deserción estudiantil en los colegios públicos se redujo de $8 \%$ en 2002 a $5,4 \%$ en 2008 , acercándose a la meta para el año 2010 de llegar a $5 \%$ en el sector oficial. Igualmente, ha pasado de tener 1'600.000 menores entre 5 y 16 años de edad por fuera de la escuela en 2002, a 997.219 en 2009. (Ministerio de Educación Nacional, Colombia, consultado el 28 de junio de 2011)

En la deserción escolar en Bogotá, es significativo señalar la diferencia de los datos suministrados por la Secretaría de Educación y los datos reportados por los colegios, en el período comprendido entre 2002-2005, en cuanto a la deserción intra-anual. (Contraloría de Bogotá, Colección de estudios 2006: 86, 87) 


\section{Cuadro 2. Deserción intra-anual en Bogotá 2002-2005}

\begin{tabular}{|c|c|c|}
\hline \multicolumn{2}{|c|}{$\begin{array}{c}\text { Información suministrada por la Secretaría de } \\
\text { Educación de Bogotá 'SED' (Censo, Dane, C- } \\
600)\end{array}$} & $\begin{array}{c}\text { Información suministrada por } \\
\text { las Instituciones Educativas 'IE' } \\
\text { de Bogotá }\end{array}$ \\
\hline 2001 & $4.5 \%$ & $4.66 \%$ \\
2002 & $3.3 \%$ & $4.78 \%$ \\
2003 & $3.1 \%$ & $5.46 \%$ \\
2004 & $3.2 \%$ & $6.0 \%$ \\
2005 & & \\
\hline
\end{tabular}

Fuente: Secretaría de Educación Distrital, Instituciones educativas distritales. Censo-DANE, C-600.

La información suministrada sugiere que desde el enfoque de la SED, la deserción intra-anual ha venido en descenso, mientras que los colegios reportan que es un fenómeno que se mantiene en la ciudad. Es significativo resaltar, que la deserción intra-anual en Bogotá, mantiene las características esbozadas a nivel nacional en cuanto que en promedio la población masculina deserta más que la femenina, $56 \%$ de abandonos en niños, frente a $45 \%$ de retiros en niñas para el año 2005, manteniéndose este promedio durante los años precedentes. (Contraloría de Bogotá, Colección de estudios 2006: 84, 85)

\section{Figura 4. Deserción escolar en Bogotá 2002-2005 por género}

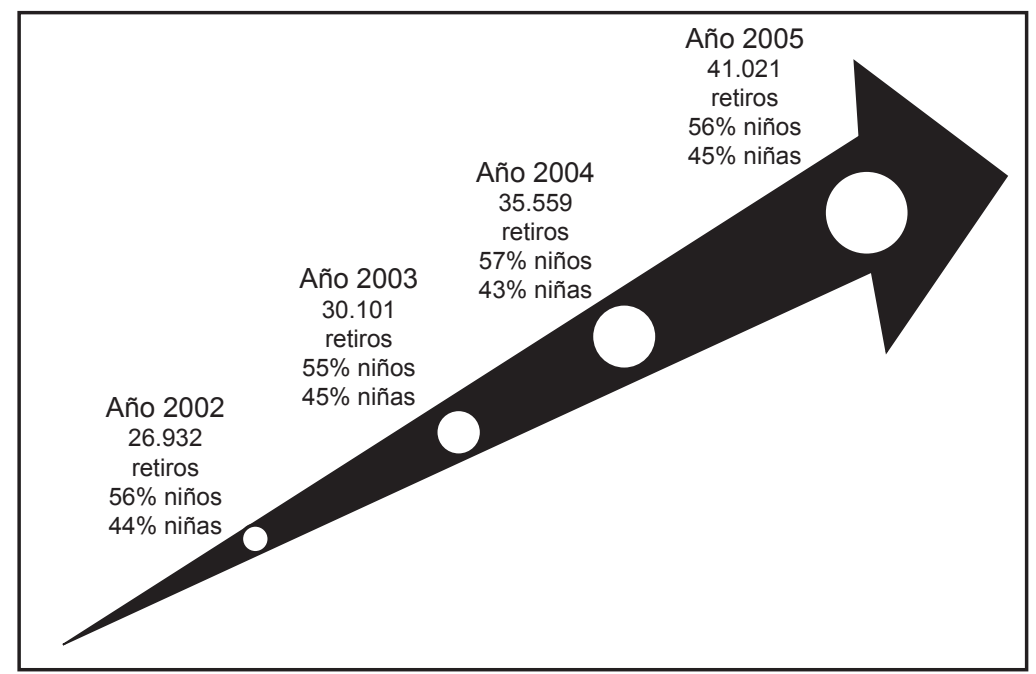

Fuente: Secretaría de Educación Distrital, Instituciones educativas distritales. Censo-DANE, C-600. 
A diferencia del nivel nacional que señala como principal razón de la deserción escolar los problemas económicos, en Bogotá, las tres principales razones están relacionadas con el cambio de domicilio, los problemas familiares y el trabajo infantil en su orden. Estas razones se mantienen estables durante el período 2002-2005. (Contraloría de Bogotá, Colección de estudios 2006: 87- 90)

\section{Cuadro 3. Razones del porcentaje de deserción escolar en Bogotá 2002-2005}

\begin{tabular}{|l|r|r|r|r|}
\hline RAZONES & 2002 & 2003 & 2004 & 2005 \\
Cambio domicilio & $62.17 \%$ & $62.63 \%$ & $55.76 \%$ & $60.56 \%$ \\
Problemas familiares & $6.60 \%$ & $6.79 \%$ & $6.18 \%$ & $5.34 \%$ \\
Trabajo infantil & $5.29 \%$ & $5.56 \%$ & $4.79 \%$ & $3.77 \%$ \\
Problemas de transporte & $5.01 \%$ & $4.55 \%$ & $6.36 \%$ & $4.95 \%$ \\
Falta de dinero & $4.59 \%$ & $4.93 \%$ & $4.91 \%$ & $4.39 \%$ \\
Embarazos & & & $3.50 \%$ & \\
Problemas académicos & $3.05 \%$ & & $3.26 \%$ & $3.19 \%$ \\
No especificadas & $8.27 \%$ & $7.51 \%$ & $11.16 \%$ & $12.97 \%$ \\
\hline
\end{tabular}

Fuente: Contraloría de Bogotá

Diferentes investigaciones realizadas en el contexto nacional e internacional y los mismos datos empíricos de esta investigación, señalan que la desmotivación y el aburrimiento por el estudio se convierten en razón importante para que los niños/as y jóvenes pierdan interés y deserten de la institución educativa.

Los datos al respecto son paradójicos en cuanto niños/as y jóvenes consideran aburrido estudiar, más no asistir a la institución educativa; así lo señalan los resultados del estudio patrocinado por UNESCO, a 17 millones de adolescentes en 32 países como parte de su Programa Internacional para la Evaluación de Estudiantes (PISA):

[...] Las mayores tasas de aburrimiento se encuentran en Alemania (67 por ciento), Grecia y España (66 por ciento)... La gran mayoría visualiza la escuela como un lugar donde se pueden hacer amigos fácilmente (82 por ciento), donde se sienten cómodos (75 por ciento) y donde a los demás estudiantes parecen simpatizarles ( 77 por ciento). Sólo el 14 por ciento se siente incómodo y el 10 por ciento declara sentirse solo... "Cuando los alumnos se aburren en clase, no vacilan en hacértelo saber y esa es, sin duda, la parte más difícil de enseñar a adolescentes hoy en día", comenta la socióloga francesa Françoise Dubet. Ya pasó la época cuando los estudiantes escuchaban en silencio mientras el maestro exponía. Los adoles- 
centes de hoy insisten en su derecho a hablar. (Unesco, Educando a los adolescentes: 5)

De acuerdo con los resultados de la Encuesta de Calidad de Vida 2003, realizada por Corpoeducación en 2006 y las causas principales por las que los niños y los jóvenes no asisten a instituciones educativas, como la falta de dinero y el poco gusto por estudiar entre los jóvenes de 12 a 17 años, reportamos un caso de una madre de familia participante de esta investigación:

[...] Yo tuve dos hijos en esta institución pero ellos no terminaron de estudiar, mi hijo mayor no quiso estudiar más porque no le gustó el estudio. Yo lo traía a estudiar y eso era una lloradera por la calle; él estudió como hasta los nueve años. Hizo tercero primaria; cuatro veces me repitió tercero... entraba a estudiar y se sentaba en una silla, él no molestaba ni nada, era juicioso y se sentaba ahí a tomar el refrigerio. No estudió más; aprendió a leer y a escribir fue por fuera del colegio en el trabajo; él se quedó con tercero de primaria; ahora tiene dieciocho años. (Sesión No. 5, Madre 40, mayo de 2009)

La indisciplina también se convierte en un factor que incide en la deserción escolar, pero como en el caso que presentamos, está asociada a fracaso escolar, a las medidas disciplinares de los colegios que optan por retirar los estudiantes que no son funcionales al sistema y al poco apoyo familiar y académico para mantener al niño en el proceso educativo:

[...] Mi otro hijo estudió hasta sexto, desde pequeñito me ha tocado luchar con él porque es muy indisciplinado y ponía a las profesoras en apuros. Tampoco quiso estudiar y lo sacaron del colegio por la disciplina, entonces yo le dije "ya no estudia más" a veces se ponía a llorar porque no lo traía a estudiar, el estudio si le gustaba pero entonces es que es muy indisciplinado, no le digo que ponía a padecer a las profesoras y todavía en la casa me hace padecer a mí; él parece todavía un bebé pequeño, y ya tiene diecisiete años, él hizo hasta sexto. Este año lo inscribí, pues me dijo que quería estudiar por la noche y lo coloqué a estudiar y no estudió sino una semana y no quiso volver más por la noche que porque aquí hay mucha gaminería y como a él no le gustan los vicios entonces no quiso estudiar más; se quedó en sexto grado, estaba yendo a un programa de IDIPRON, allá les estaban enseñando también a estudiar, les ponían planas, no volvieron porque según los sacaron de la sede de la calle 170 y empiezan hacer una casa por aquí cerca, pero que hasta que no tengan hartos niños no hacen nada entonces mi hijo no volvió tampoco. (Sesión No. 5, Madre 40, mayo de 2009) 
Algunos estudios han señalado que dentro de los motivos para que los estudiantes no quieran asistir al colegio se encuentran relacionados con problemas interpersonales, agresión entre pares, aislamiento y rechazo, igualmente datos encontrados en esta investigación señalan la misma situación. (García et. al. 2010: 86)

Un menor estudiante de sexto grado manifiesta que a consecuencia de una pelea con un compañero de curso no quiso volver a estudiar, "estábamos apostando plata y me hizo trampa, peleamos y él me iba a chuzar así que no quise volver más, no le conté a nadie, no me gusta contarle a nadie lo que me pasó". (Comisaría de familia, Localidad Suba, marzo de 2008)

Los entornos escolares violentos y las presencias de grupos juveniles y de adultos semi organizados y organizados en conflicto con la ley, son otro factor a tener en cuenta en la deserción escolar. (Marcial, 2004)

Encontramos en Bogotá, una institución educativa con el síndrome de las aulas vacías, es decir con los más altos niveles de deserción colectiva asociada a problemas de administración interna, indiferencia de los profesores y a problemas del entorno escolar en donde se evidenció la existencia de pandillas, población desmovilizada de actores armados, población desplazada por el conflicto político, población infanto juvenil reportada por el ICBF del programa de libertad asistida, asedio de bandas delincuenciales con micro tráfico sobre el colegio, amenazas de limpieza social, consumo de alcohol y drogas, hurto en todas sus expresiones, negocios barriales articulados a actividades ilícitas que vinculan como clientes principales a niños/as y jóvenes, proxenetismo y porte de armas, entre otros.

A la fecha de esta investigación, encontramos en dicho colegio, doce aulas desocupadas, ¿cuántos niños caben en doce aulas en las jornadas mañana tarde y noche?, ¿cuántos niños salieron del colegio?, ¿por qué esa salida masiva de niños y niñas?

En el testimonio de una madre de familia podríamos encontrar algunas explicaciones:

[...] Mi hija hasta este año es que está acá, pero yo siempre he escuchado que este colegio es muy pesado que porque hay mucho niño pandillerito, mucha pandilla peligrosa y que más en la noche, la mala fama es por eso, 
que aquí había cualquier clase de gente y que aquí no se hacía nada y aquí se chuzaba el uno al otro que porque miraba a la muchacha o porque venía de fuera y si tenían la amiga aquí y el otro compañero la miraba o la saludaba o salía con ella, ya se formaba el problema por eso. Es primer año que yo estoy con mi hija acá. (Sesión No. 5, marzo de 2009)

\section{Expulsión escolar}

Entendemos por expulsión escolar la práctica de disciplinamiento que se aplica ante faltas consideradas como graves en los reglamentos escolares y que conlleva sacar, retirar o echar a un niño, niña o joven del colegio por problemas académicos incumplimiento de normas o problemas convivenciales que, en la mayoría de veces, tienen que ver con eventos asociados a manifestaciones de violencia escolar.

Aunque el Código de Infancia y Adolescencia, en el Artículo 41 sobre Obligaciones del Estado, prevé el diseño y la aplicación de estrategias para la prevención y el control de la deserción escolar y para evitar la expulsión de los niños, las niñas y los adolescentes del sistema educativo, encontramos datos empíricos que demuestran la prevalencia de esta práctica en el sistema educativo colombiano. Por lo menos así lo demuestran los datos obtenidos en Bogotá. (Observatorio Legislativo de Opinión, 2007: 356)

A diferencia de las demás prácticas de disciplinamiento escolar, evasión, ausentismo, desescolarización, deserción; la expulsión significa que previo proceso interno, el colegio toma la decisión de cancelar el cupo en esa institución educativa, de retirarlo, de sacarlo.

Una particularidad de esta modalidad en los casos encontrados, es que al tomar la decisión de expulsión, la institución educativa, las familias y los estudiantes implicados quedan a la deriva en una trashumancia escolar buscando el colegio que los acepte a sabiendas de los antecedentes académicos o convivenciales. Pudimos evidenciar claramente cómo se van configurando instituciones educativas en las localidades que por sus condiciones se van especializando en recibir los estudiantes que ninguna otra institución recibe, y el estigma social recae sobre ellas al tener poblaciones escolares que han sido rechazadas, marginadas, estigmatizadas y expulsadas. 
Ante la pregunta a padres y madres en Bogotá, sobre los procedimientos escolares, cuando un hijo o hija comete una falta, nos encontramos con respuestas como éstas:

[...] Primero le llama la atención el coordinador del curso, luego lo mandan al coordinador académico, luego lo mandan con el rector; después ya citan a los padres o acudientes y hablan con uno y le dan consejos al muchacho y ya, si el muchacho se compromete a no volver hacer eso, ya queda la llamada de atención ahí; si a la próxima llamada de atención vuelve otra vez, entonces, son los que van sacando del colegio. (Sesión No. 5, Madre 006, marzo de 2009)

Una orientadora reconoce que en diferentes eventos de expulsión escolar no se sigue el debido proceso y que mecanismos de restitución de derechos consagrados en la Constitución Política de Colombia, como el derecho de petición y la tutela, permiten que las instituciones educativas modifiquen sus decisiones y restituyan el derecho a la educación de niños, niñas y adolescentes: "por ejemplo, una vez tocó recibir un niño, después de que lo habían echado, lo habían trasladado, le habían hecho un traslado en noveno. (Entrevista a orientadora, febrero de 2009)

De manera inusual encontramos padres y madres de familia que aceptan positivamente la expulsión escolar de sus hijos, como en el caso de una estudiante que fue expulsada por presentar altanería, grosería e irrespeto a la autoridad de los profesores. La madre de familia reconoce justa la medida tomada por las autoridades académicas, en el sentido que acepta que su hija tiene problemas de comportamiento imposibles de corregir por parte de los profesores, a sabiendas que ellos están impedidos a reprender su hija a golpes, como sí lo puede hacer ella como madre de familia en la casa. (Entrevista a la familia, Madre 008, febrero de 2009)

En conversaciones con esta madre de familia, reconoce que en su historia personal también fue expulsada del mismo colegio cuando ella fue estudiante, lo que de alguna manera le permite incorporar la experiencia de tener una hija por fuera del sistema educativo. Otro elemento a tener en cuenta en este caso, es el hecho que la madre trabaja en el sector informal como vendedora ambulante y el hecho de tener una hija que no estudia, le significa a apoyo laboral para las ventas callejeras durante el día.

Esta misma madre, tiene otro hijo de 12 años, que también fue expulsado del colegio el año anterior, por faltas de disciplina y mal comportamiento, al respecto la madre 
dice: "el año pasado también me lo sacaron del colegio, porque el niño es terrible, se les saltaba el muro, no copiaba y es flojo para la lectura". (Entrevista a la familia, Madre 007 y 008, febrero de 2009)

A continuación, graficamos el tipo de familia a la que nos referimos en los párrafos anteriores. Se trata de una familia con bajos recursos económicos y baja escolaridad, de estructura poligenética, en donde la madre ha tenido uniones sucesivas, de las cuales le han quedado hijos, que se han ido agregando a los de las nuevas uniones. De los siete hijos que reporta esta madre de familia, dos han sido expulsados del colegio quedando uno de ellos desescolarizado, otro hijo presentó intento de suicidio y otra hija presenta problemas alimenticios. Los hijos que han estado por fuera del sistema educativo han trabajo ayudándole con las ventas ambulantes.

\section{Figura 5. Tipo de familia y problemáticas escolares asociadas}

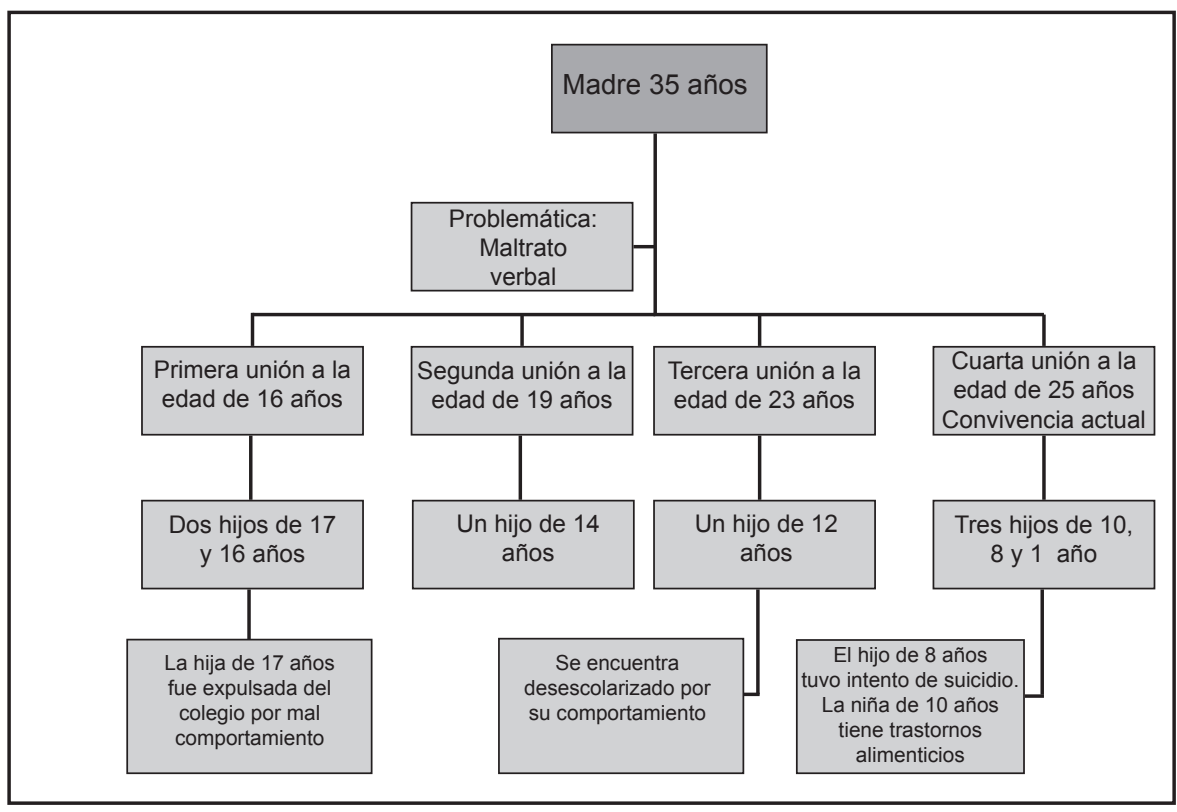

Fuente: Elaborado a partir de los datos recogidos.

De acuerdo con investigaciones en América Latina sobre tendencias sociales y educativas, encontramos que:

[...] El nivel socioeconómico es un factor de gran incidencia en las trayectorias escolares de los adolescentes. Si se toma en cuenta el origen social de 
los niños y adolescentes que están fuera del sistema educativo, se observa que, en las edades más tempranas, la gran mayoría -el 75\%- proviene de los niveles sociales más bajos Si bien la dimensión económica es central para entender el alejamiento de los adolescentes de sus escuelas, sin duda hay otras dimensiones que debe ser contempladas. (Sistema de información de tendencias educativas en América Latina, 2006).

Un elemento importante para resaltar, en este caso, es el hecho que la madre manifiesta que al no estar los hijos estudiando, ella se los lleva a trabajar en las ventas ambulantes. Encontramos así las relaciones de informalidad asociadas a la exclusión escolar y al trabajo infantil, situación que es común en América Latina:

[...]Al observar lo que ocurre con las tasas de empleo entre los adolescentes que no asisten a la escuela, se evidencia que estas son considerablemente más altas, incluso para Chile, Argentina, República Dominicana, Brasil y Bolivia. Por cierto, este último es el país con mayor diferencia porcentual entre la tasa de empleo adolescente de quienes no asisten a la escuela y la tasa de empleo registrada entre los adolescentes que sí lo hacen, la misma es de 44.4 puntos porcentuales. También Ecuador, Colombia, Nicaragua y Honduras presentan un panorama similar respecto de este punto, con alrededor de 40 puntos porcentuales de diferencia entre las tasas de empleo de los adolescentes excluidos del sistema educativo y las tasas de empleo de los jóvenes que sí asisten a la escuela. De todos modos, es importante tener en cuenta que en todos los países considerados la tasa de empleo de aquella porción de adolescentes que no asiste a la escuela al menos duplica la tasa de empleo de la población adolescente que sí lo hace. (Sistema de información de tendencias educativas en América Latina, 2010).

Encontramos casos reportados de expulsión escolar por consumo de alcohol, un adolescente de 15 años dice "todo es verdad, me la paso con mis amigos a ellos también los echaron del colegio". (Comisaría de familia, Localidad Usaquén, enero de 2009)

Por problemas comportamentales:

[...] el niño de 10 años, ha salido de varios colegios por su comportamiento. El niño está al cuidado de una tía abuela porque ha sido rechazado por la familia materna. Su comportamiento presenta conducta esquizoides. (Comisaría de familia, Localidad Santa Fe, abril de 2008)

Por maltrato físico entre niñas, como el caso de la niña que fue agredida por parte de un grupo de niñas y a causa de las lesiones estuvo incapacitada por 
15 días; unas de estas niñas fueron suspendidas y las otras retiradas del plantel porque se les canceló el cupo, o por casos como el de difamación en donde al agresor le suspendieron el cupo. (Sesión No. 5, Madre 005, 6 de marzo de 2009)

Estamos de acuerdo con la conclusión de un estudio que señaló que si un agresor o agresora es expulsado de una institución educativa, encontrará otro colegio en dónde actuar y lo mismo ocurrirá con las víctimas, luego, de ninguna manera estas sanciones disciplinarias que suspenden, sancionan, desescolarizan o expulsan a los actores de la violencia escolar, son las más indicadas para resolver el problema y así se ha demostrado, pues al trasladar el problema de una institución a otra, lo que pasa es que se involucran cada vez nuevos actores y se continúan los ciclos de la violencia. (Matoneo en las aulas, Revista Cambio 12, noviembre de 2006) 



\section{A manera de conclusiones}

Podemos afirmar que la violencia que se presenta en la institución educativa es multi causal y multi relacional y que todos los actores involucrados son responsables de la violencia y todos pueden hacer aportes para enfrentarla desde sus diferentes realidades.

Se debe dar una solución global al problema procurando la participación de todos y teniendo en cuenta los diferentes factores que intervienen: maestros, estudiantes, familias, directivos docentes y comunidad que rodea la institución escolar. Las soluciones estarían dadas en el nivel individual, grupal, institucional y cultural. Así mismo se reconoce la importancia de las soluciones negociadas entre maestros y directivos.

Intentar negar los conflictos que se generan en la escuela, sólo ayuda a aumentar la violencia. Si la escuela acepta el conflicto como fenómeno que ocurre y a veces genera, se puede esperar que los agentes involucrados cambien la perspectiva en un sentido positivo y se abran espacios de diálogo y discusión.

Las nuevas obligaciones de las instituciones educativas en Colombia, provenientes del Código de Infancia y Adolescencia, establecido mediante Ley 1098 de 2006, que implican obligaciones especiales, obligaciones éticas fundamentales, obligaciones complementarias y prohibición de sanciones, imponen nuevas responsabilidades a padres y maestros frente a la responsabilidad parental y pedagógica.

La posición del maestro y la consideración que se le otorga a su trabajo en el mundo contemporáneo, ha disminuido de manera drástica, sus condiciones de trabajo han cambiado, su jornada laboral la vive en un activismo exagerado, y la motivación por su trabajo ha disminuido, situación que obliga a pensar en mecanismos de formación permanente y estímulos a su labor. Así mismo, las condiciones en que ha sido formado no permiten que tenga las herramientas necesarias para enfrentar la violencia en el ámbito escolar. Las Facultades de Educación tienen un inmenso reto frente a la formación de los nuevos maestros en el campo de la formación en valores, y para aquellos que están en ejercicio se requieren propuestas alternativas y creativas. 
Así mismo, el apoyo institucional es fundamental si se quiere que el maestro se involucre en su tarea de educador. Se evidencia también la carencia por parte de las instituciones de involucrar a la familia de una manera activa, pocos proyectos las implican y los que inician, tampoco se integran a una visión global de la institución.

Los problemas analizados con relación al clima escolar, suponen una mirada más centrada en el clima institucional, que junto con el clima del aula, las condiciones de espacio y temporalidad institucional, podrían promover una mejor gestión de las relaciones interpersonales entre estudiantes, entre éstos y los maestros y entre maestros.

El análisis también nos muestra la posición del maestro en la contemporaneidad. Pareciera que el respeto y la consideración de su trabajo han disminuido, se observa una menor motivación por su trabajo. $Y$ las condiciones del ejercicio docente han cambiado. Se le exige un activismo que supera sus posibilidades. La formación permanente, la reflexión y el diálogo permitirían afrontar los conflictos de otra manera. Se constata que el maestro como modelo de los alumnos tiene poco nivel de influencia con relación al pasado. En algunas ocasiones el maestro se revela como modelo negativo con su actuar. El tipo de relaciones que establecen maestros y estudiantes son fundamentales para el desarrollo armónico del trabajo.

Las tensiones entre familia y escuela adquieren, en la contemporaneidad, un nuevo matiz a partir de las nuevas disposiciones con relación a las prácticas de disciplinamiento, al uso del castigo, y en los procesos de exclusión, la investigación permite entender sus diferentes modalidades y su gravedad. 


\section{Referencias bibliográficas}

Abraham, Ada. (2000). (Comp). El enseñante es también una persona. Barcelona: Gedisa. Aries, Philippe. El niño y la vida familiar en el Antiguo Régimen. Madrid: Taurus, 1987.

Bedoya, Juliana. (2007,marzo 22). Avalancha de niños infractores en primera semana del nuevo sistema judicial para menores de edad. Revista Semana. Bogotá, D.C. [[En línea]], [Consultado 27 junio 2011]. Disponible en: <http://www.semana.com/on-line/ avalancha-ninos-infractores-primera-semana-del-nuevo-sistema-judicial-para-menores-edad/101684-3.aspx>

Bergalli, Roberto \& Rivera Beiras, Iñaki (2007). (Coordinadores). Jóvenes y adultos: el difícil vínculo social. Barcelona: Anthropos.

Betthelheim, Bruno. (1984).Le Monde de l'Education. En: Interview.122.Paris.

Blaya, Catherine et. al. (2006, enero-abril). Clima y violencia escolar: un estudio comparativo entre España y Francia. Revista de educación. 339. p. 293-315. [[En línea]]. Disponible en: http://www.revistaeducacion.mec.es/

Bourdieu, Pierre \& Passeron, Jean Claude. (1977). La reproducción: Elementos para una teoría del sistema de enseñanza. Barcelona: Editorial Laia.

Brawer, Ana. (2006). Cartografía de las violencias juveniles. Escenarios fronteras y desbordes. En: Miradas interdisciplinarias sobre violencia en las escuelas. Buenos Aires: Ministerio de Ciencia y Tecnología de la Nación. Observatorio argentino de Violencia en las escuelas.

Brawer, Mara. (2006). Evaluación criminológica de la violencia en la adolescencia En: Miradas interdisciplinarias sobre violencia en las escuelas. Buenos Aires: Ministerio de Educación Ciencia y Tecnología de la Nación. Observatorio argentino de violencia en las escuelas.

Carbonell, Luisa. (2009). Violencia escolar: Literatura sobre conflicto escolar. [En línea] [Consultado 11 julio 2011]. Disponible en: http://violeciaescolar.blogspot.com/2009/05/ literatura-sobre-conflicto-escolar.html..

Carpinelo, Sharon. (2005). Estrategias para la prevención de la violencia. Sistema de estudios de salud mental para los neoyorkinos. [Consultado 30 junio 2005]. Disponible en: <www.omh.state.ny.us/omhweb/spansite/sv/estrategiess.htm http://www.omh.state.ny.us/ omhweb/spansite/sv/estrategiess.htm>

Camacho, Alvaro. \& Guzmán, Alvaro. (1990) Ciudad y violencia. Contribuciones al estudio de la violencia urbana en Colombia. Bogotá: Ediciones Foro Nacional.

Congreso de la República, Colombia. (2006, Noviembre 8). Ley 1098. Por la cual se expide el Código de la Infancia y la Adolescencia. [[En línea]]. Diario Oficial. Bogotá, D.C., 2006. No. 46446. [Citado 25 octubre 2010]. Disponible en: http://www.presidencia.gov.co 
Congreso de la República, Colombia. (1994, Febrero 8). Ley 115. Por el cual se expide la Ley General de Educación. Diario oficial. Bogotá D.C., 1994. No. 41.214.

Conferencia Mundial sobre Educación para Todos. Declaración mundial sobre educación para todos y marco de acción para satisfacer las necesidades básicas de aprendizaje. (1990, Marzo 5-9). Tailandia, Jomtien. Documentos de trabajo WCEFA. Nueva York: UNESCO. [En línea] [Consultado 20 enero 2011] Disponible en: http://www.oei.es/quipu/ marco_jomtien.pdf.

Contraloría de Bogotá D.C. (2006). Deserción escolar. En: Colección de estudios. [En línea]. (2006) [Consultado 02 abril 2011]. Disponible en: http://www.contraloriabogota.gov.co/wps/wcm/connect/be4f46004f42abc8a3ffbf55c8c132e5/estudios2006N1. pdf?MOD=AJPERES

Corpoeducación. (2006). Hay avances, pero quedan desafíos. Informe de progreso educativo de Colombia. [[En línea]]. Bogotá: 2006 [Consultado 8 de abril 2011]. Disponible en: http://www.mineducacion.gov.co/cvn/1665/articles-114383_archivo_pdf.pdf.

Corpoeducación. (2006). Situación de la educación preescolar, básica y media. Análisis del periodo 2000-2004. En: Situación de la educación preescolar, básica, media y superior en Colombia. (2ª .Ed.). [En línea]. Bogotá: 2006. [Consultado 8 abril 2011]. Disponible en: http://www.oei.es/quipu/colombia/situacion_educ_basica_media2006.pdf.

Cruz, Carmen Inés. (1997) La cara oculta de la escuela. Fondo Editorial Coruniversitaria. Cuatro estrategias para la repitencia y la deserción. Al tablero. [En línea]. 2003, no. 21 [Consultado 01 abril 2011]. Disponible en: http://www.mineducacion.gov.co/1621/ article-87969.html

Chagas, Raquel. .(2005) Los maestros frente a la violencia entre los alumnos. En: Revista Mexicana de Investigación Educativa. Año/ (Vol. 10). 27.

Chesnais, Jean Claude. (1981). Historia de la violencia. París: Lafond.

Chemen, Silvia. (2001). Qué puede hacer la escuela con la violencia. En: Violencia y escuela. Miradas y propuestas concretas. Buenos Aires, Argentina: Paidós.

Chiappe, Clemencia. (1999). Violencia en la escuela. Bogotá: Editorial Idep.

Defensor del Pueblo, España. (2007). Violencia escolar: El maltrato entre iguales en la Educación Secundaria Obligatoria 1999-2006. Actualización del Informe 2000. Madrid: Defensor del Pueblo. Informes, estudios y documentos.

Del Barrio, Cristina et al. (2003). Las distintas perspectivas de estudiantes y docentes acerca de la violencia escolar. En: Estudios de juventud. 62.

Delors, Jacques. (1996). La educación encierra un tesoro. Madrid: Santillana y UNESCO. [Consultado 20 enero 2011], Disponible en: http://www.unesco.org/education/pdf/ DELORS_S.PDF.

Domínguez Morano, Carlos. (2007). Uno Sólo es Vuestro Padre. Eclesiología de comunión y psicoanálisis. [[En línea]], [consultado 13 de agosto de 2010] Disponible en: http:// www.aiempr.org/articles/pdf/aiempr240.pdf.

Dubet F. et. al. (2006). L'hipocrisie scolaire. En: TENTI, Fanfani. El oficio de Docente. Vocación, trabajo y profesión en el siglo XXI. Buenos Aires: Siglo XXI Editores. p. 131. 
Durkheim, Emile. (2008). El Suicidio. Citado en: Colombia. Instituto Nacional de Medicina Legal y Ciencias Forenses. Forensis 2008. Datos para la vida. Bogotá, D. C.: Quebecor.

Foucault, Michel. (1986). Vigilar y castigar. Madrid: Siglo XXI Editores.

García Sánchez, Bárbara Yadira. (2006, enero-junio). Consideraciones históricas sobre la relación familia y educación. En: Revista Educación y Ciencia. 8. pp. 3-18

García Sánchez, Bárbara Yadira. (2007). De la educación doméstica a la educación pública: Transiciones de la Colonia a la República. Bogotá: Universidad Distrital.

García Sánchez, Bárbara Yadira. (2008). Familia, escuela y Barrio: Un contexto para la comprensión de la violencia escolar. En: Revista Colombiana de Educación. (Vol. 55). fasc. 1. p. 108-124.

García Sánchez, Bárbara Yadira. (2003). Los Núcleos de Educación Familiar. Investigación Participativa para la prevención de las violencias difusas en la Escuela, la Familia y el Barrio. Tesis para obtener el grado de magister en Investigación y desarrollo. Universidad Nacional de Colombia. Facultad de Sociología, Bogotá, Colombia.

García, Sandra; Fernández, Camila \& Sánchez, Fabio. (2010). Deserción y repetición en los primeros grados de la básica primaria: factores de riesgo y alternativas de política pública. [[En línea]]. [Consultado 2 abril 2011]. Disponible en:http://www.educacioncompromisodetodos.org/datos/274A1_ECT\%20Desercion\%20y\%20repeticion.pdf

Goiria, Madalen. ( 2002). Historia del movimiento desescolarizador en el estado Español. Ponencia presentada en el Seminario la educación en ciencias sociales: ¿en qué estamos y hacia dónde vamos? Bogotá: Universidad Nacional de Colombia. S.f. [En línea] Disponible en: http://madalen.wordpress.com/seminario-de-colombia/ .

Gómez Nashiki, Antonio. (2005, julio-septiembre). Violencia e Institución Educativa. En: Revista mexicana de Investigación Educativa. (Vol. X). 26. pp. 693-718.

Guerrero Barón, Javier. (2011, Abril). El barrio: escenario de violencias juveniles que se articulan en la escuela. En: Conferencia mundial sobre violencia escolar (Vol. 7-9) Memorias. Mendoza, Argentina.

Guillote, Alain. (3003). Violencia y educación. Incidentes, incivilidades y autoridad en el ambiente escolar. Buenos Aires: Amorrortu Editores.

Herrera, Marisa \& Spaventa, Verónica. (2010). Vigilar y Castigar... El poder de corrección de los padres. Revista Jurídica de la Universidad de Palermo. 10. [En línea] [Citado 10 agosto 2010] Disponible en: http://www.palermo.edu/derecho/revista_juridica/pub10/10Jurica02.pdf.

Illich, Iván. (1985). La sociedad Desescolarizada. México. [En línea]. [Consultado 2 julio 2011]. Disponible en: http://www.mundolibertario.org/archivos/documentos/lvnlllich_lasociedaddesescolarizada.pdf

Illich, Iván. (2006). Obras Reunidas I. México: Fondo de Cultura Económica.

Imberti, Julieta. (2001). Violencia y escuela. Miradas y propuestas concretas. México: Paidós.

Instituto Nacional de Medicina Legal y Ciencias Forenses, Colombia. (2008) Forensis. Datos para la vida. Bogotá, D. C.: Quebecor Word. 
Instituto Colombiano de Bienestar Familiar. (2008). Informe de niñez Colombia. [Consultado 18 enero 2011]. Disponible en: http://www.scribd.com/doc/6331984/Informe-de-NinezColombia.

Jodelet, Denise. (1984). Las representaciones sociales, fenómenos, concepto y teoría. Psicología social. (Vol. 2). (Ed.), Serge Moscovici. Barcelona: Paidós.

Kaës, René et. al. (1998). La Institución y las instituciones. Estudios psicoanalíticos. Buenos Aires: Paidos.

La nueva política de seguridad. (2011). Revista Semana. [En línea] [Consultado 1 junio 2011] Disponible en: <http://www.semana.com/politica/nueva-politica-seguridad/157785-3.aspx

Marcial, Rogelio. (2004). Entre el Aula y la Esquina. En: Revista de Educación y cultura de la sección 47. [En línea]. [Citado 25 octubre 2010]. Disponible en:www.latarea.com.mx

Martínez Boom, Alberto. (2004). De la escuela expansiva a la escuela competitiva. Dos modos de modernización en América Latina. Barcelona: Anthropos.

Matoneo en las aulas. (2006, Noviembre 12). [En línea]. Revista Cambio. Bogotá, D.C. [Citado 1 de agosto de 2009] Disponible en: http://psicologia.uniandes.edu.co

Maturana, Humberto. Biología del fenómeno social. Citado en: Colombia. Instituto Nacional de Medicina Legal y Ciencias Forenses. Forensis 2008, p. 65.

Miermont. Jacques. (1987). Dictionnaire de thérapies familiales, theories et practiques. París: Puyot.

Ministerio de Educación Nacional. Colombia: Informe Estadístico 2010. Del 8\% al 5,4\% disminuyó la tasa de deserción estudiantil en educación básica. [En línea] [Consultado, 28 junio 2011] Disponible en: http://www.oei.es/noticias/spip.php?article5983\&debut_5ult imasOEI=15.

Ministerio de la Protección Social, Dirección Nacional de Estupefacientes, Colombia. (2008). Estudio Nacional de Consumo de Sustancias Psicoactivas en Colombia 2008. Bogotá: Guadalupe.

Monclus, Antonio \& Saban Carmen. (2006). Violencia escolar. Actuaciones y propuestas a nivel internacional. Barcelona: Davinci Continental.

Naciones Unidas. Consejo Económico Y Social. (2004). Los derechos económicos, sociales y culturales: el derecho a la educación. Informe presentado por Katarina Tomasevski, relatora especial sobre el derecho a la educación. [[En línea]] 2004 [Consultado 25 noviembre 2010] Disponible en: http://www.unhchr.ch/Huridocda/Huridoca.nsf/0/4ae57c3d9 6fddd45c1256e46003c3bd4/\$FILE/G0410331.pdf.

Moscovici, Serge. (1961). El psicoanálisis su imagen y su público. Citado en: CHAGAS, Raquel. Los maestros frente a la violencia entre los alumnos. Revista Mexicana de Investigación Educativa. Año/ (Vol. 10). 27, p. 1081.

Observatorio Legislativo y de Opinión (2007). Nuevo código de infancia y adolescencia. Antecedentes, análisis y trámite legislativo. Universidad del Rosario, Bogotá, Colombia.

Oficina de las Naciones Unidas contra la droga y el delito (UNODC). (2004, Noviembre 12). Hacia un nuevo paradigma: miradas interdisciplinarias sobre modelos y metodologías. Justicia juvenil: retos y perspectivas a nivel internacional. En: Foro sobre el menor 
infractor. Medellín, Colombia. [En línea] 2004. Disponible en: http://www.unicef.org.co/ Ley/Al/12.pdf.

Organización de las Naciones Unidas para la Educación, la Ciencia y la Cultura. (2003, enero-marzo). 4. Educando a los adolescentes [[En línea]]. París: (UNESCO). [Citado 25 de octubre de 2010]. Disponible en:<http://unesdoc.unesco.org>.

Ortega Salazar, Sylvia; Ramírez Mocarro, Marco \& Castelan Cedillo, Adrián. (2005). Estrategias para prevenir y atender el maltrato, la violencia y las adicciones en las escuelas públicas de la ciudad de México. En: Revista Iberoamericana de Educación. 38. pp. 147169.

Ortiz, Blanca; García Sánchez Bárbara Yadira \& Santana, Carlota. (2008). El trabajo académico del profesor universitario. Universidad Distrital Francisco José de Caldas, Bogotá, Colombia.

Osorio, Fernando. (2008). Violencia en las escuelas. (2a . ed.) Buenos Aires: Noveduc.

Parra Sandoval, Rodrigo. (1986). Los maestros colombianos. Bogotá: Plaza \& Janés.

Patiño Guzmán, Carlos Andrey. (2011). Educar sin escuela. Se abre la discusión. UN. Periódico Universidad Nacional. 29. Bogotá. [En línea]. [Consultado 02 julio 2011] Disponible en: http://www.unperiodico.unal.edu.co/dper/article/educar-sin-escuela-se-abre-ladiscusion-1.html

Planella, Jordi. (1998). Repensar la violencia: usos y abusos de la violencia. Barcelona. Edit. Gedisa.

Procuraduría General de la Nación. (2006). El derecho a la educación. La educación en la perspectiva de los derechos humanos. Bogotá. [En línea]. [Consultado 5 abril 2011]. Disponible en: http://www.procuraduria.gov.co/imgs/eventos /05052006_libroeducacion.pdf.

Revista Cambio. 12. Matoneo en las aulas. (2006, Noviembre). [En línea]. Bogotá, D.C. [Citado 1 de agosto de 2009] Disponible en: http://psicologia.uniandes.edu.co

Roa, Ana. (2008). Lesiones personales. En: Forensis Bogotá: Quebecor World.

Rumbos. (2005). Juventud y Consumo de Sustancias Psicoactivas: Resultados de la Encuesta Nacional de 2001 en Jóvenes Escolarizados de 10 a 24 años. Bogotá: Presidencia de la Republica de Colombia.

Sistema de Información de Tendencias Educativas en América Latina. (2009, Abril). ¿Por qué los adolescentes dejan la escuela? Motivos de la deserción en la transición del primario al secundario. Datos destacados. [En línea], [Consultado 2 abril 2011]. Disponible en: http://www.siteal.iipe-oei.org/sites/default/files/siteal090401.pdf

Sistema de Información de Tendencias Educativas en América Latina. (2006). Informe sobre tendencias sociales y educativas en América Latina. [En línea]. 2008 [Consultado 2 abril 2011]. Disponible en: http://www.oei.es/pdfs/siteal2008.pdf.

Sistema de Información de Tendencias Educativas en América Latina. (2010). Trabajo adolescente y escolarización en 16 países de América Latina. Dato destacado 17. [En línea]. [Consultado 2 abril 2011]. Disponible en: http://www.siteal.iipe-oei.org/sites/default/ files/datodestacado_20101115.pdf.

Smith, Peter. (2005). Definition, Types and prevalence of school bullying and violence. Citado por Ortega Salazar, Sylvia; Ramírez Mocarro, Marco \& Castelan Cedillo, Adrian. 
Estrategias para prevenir y atender el maltrato, la violencia y las adicciones en las escuelas públicas de la ciudad de México. En: Revista Iberoamericana de Educación. 38.

Stone, Lawrence. (1989). Familia, sexo y matrimonio en Inglaterra 1500-1800. México: Fondo de Cultura Económica.

Tedesco, Juan Carlos. (1999). El nuevo pacto educativo: Educación, competitividad y ciudadanía en la sociedad moderna. Madrid: Anaya.

Tenti, Fanfani. (2006). El oficio de docente. Vocación, trabajo y profesión en el siglo XXI. Buenos Aires: Siglo XXI Editores.

Tomasevski, Katarina. (2004). Naciones Unidas, Consejo Económico y Social. Los derechos económicos, sociales y culturales: el derecho a la educación. Informe presentado por la relatora especial sobre el derecho a la educación. [[En línea]] [Consultado 25 noviembre 2010] Disponible en: http://www.unhchr.ch/Huridocda/Huridoca.nsf/0/4ae57c3 d96fddd45c1256e46003c3bd4/\$FILE/G0410331.pdf

Torres, Jurjo. (2006). La desmotivación del profesorado. Madrid: Morata.

Varela, José. y Ortega Francisco. (1984). El aprendiz de maestro. Madrid: Servicio de publicaciones del Ministerio de Educación y Ciencia.

Willis, Paul. Aprendiendo a trabajar. (2009). Citado en: Carbonell, Luisa. Violencia escolar: Literatura sobre conflicto escolar. (2009). [En línea] [Consultado 11 julio 2011]. Disponible en: http://violeciaescolar.blogspot.com/2009/05/literatura -sobre-conflicto-escolar.html. 
Este libro se publicó en Bogotá, Colombia, en el año 2012, con la dirección gráfica de Común Presencia Editores. 